\title{
EFFECT OF STORAGE PERIOD AND TREATMENT ON THE COMPOSITION AND DIGESTIBILITY OF OLIVE POMACE IN CATTLE
}

\author{
A Thesis \\ presented to \\ the Faculty of California Polytechnic State University, \\ San Luis Obispo
}

In Partial Fulfillment of the Requirements for the Degree

Master of Science in Agriculture with a Specialization in Animal Science

by

Alexis Cecilia Ulloa

September 2018 
(C) 2018

Alexis Cecilia Ulloa

ALL RIGHTS RESERVED 
COMMITTEE MEMBERSHIP

TITLE: $\quad$ Effect of Storage Period and Treatment on the Composition and Digestibility of Olive Pomace in Cattle

AUTHOR:

DATE SUBMITTED:

COMMITTEE CHAIR:

COMMITTEE MEMBER:

COMMITTEE MEMBER:
Alexis Cecilia Ulloa

September 2018
Dr. David Bruce Vagnoni, Ph.D. Assistant Professor of Dairy Science California Polytechnic State University

Dr. Keela Marie Trennepohl, Ph.D., Assistant Professor of Animal Science Western Illinois University

Dr. Juan Romero, Ph.D., Assistant Professor of Animal Nutrition University of Maine 


\begin{abstract}
Effect of Storage Period and Treatment on the Composition and Digestibility of Olive Pomace in Cattle
\end{abstract}

\title{
Alexis Cecilia Ulloa
}

Utilizing local by-products can serve to significantly reduce the current feed costs for ruminant producers. The objective of this study is (1) to evaluate the effects of chemical and bacterial inoculants in combination with ensiling, on the nutritional value and ensiling compatibility of olive pomace (OP) and (2) to identify the most biologically favorable treatment and ensiling day of OP for feeding to cattle. Freshly centrifuged OP (Olivas de Oro Olive Company, Creston, CA) was treated with one of four treatments: (1) no additives (control; CONT); (2) urea applied at 5\% of DM (UREA; Agrium U.S. Inc, Loveland, CO); (3) SiloSolve MC (SS; a mixture of Enterococcus faecium M74, Lactococcus lactis SR3.54, and Lactobacillus plantarum CH6072 applied at $1.5 \times 10^{5} \mathrm{cfu} / \mathrm{g}$ of fresh forage; Chr. Hansen A/S, Hørsholm, Denmark); (4) SiloSolve MC applied at the same rate as treatment 3 with calcium oxide (CAO; Flinn Scientific, Batavia, IL) applied at 5\% of DM. Treated OP was ensiled in quintuplicates into 20-L laboratory silos with vents, which were sealed for 2, 10, 60, and $120 \mathrm{~d}$ in a completely randomized design. At $0 \mathrm{~d}$, DM was 2 and 5\% higher for UREA and CAO, respectively, while ash and $\mathrm{pH}$ were highest for CAO. Fat tended to be higher for SS and CP was highest for UREA by $60 \mathrm{~d}(23.8 \%)$. CAO had significantly lower fiber portions, ethanol and yeasts $(P<0.05)$, and higher acetic acid than CONT. No significant differences were observed at 12 and $24 \mathrm{~h}$ in situ compared to CONT, yet at $48 \mathrm{~h}$, NDFD was greatest for CONT and SS $(P<0.001)$. Lactic acid increase with prolonged ensiling with UREA having the highest content at $120 \mathrm{~d}(0.716 \%)$ and acetic 
decreased for CONT, SS, and CAO. SS contained the most LAB (8.5 log cfu/ fresh g). Yeasts, molds, and sugars significantly decreased with ensiling. In conclusion, OP was determined to be a viable nutritional source for ruminants given its chemical composition and effective preservation after $120 \mathrm{~d}$ of ensiling that could be improved with chemical and bacterial inoculants.

Keywords: olive pomace, cattle, digestibility, inoculant 


\section{ACKNOWLEDGMENTS}

First and foremost, I would like to thank Dr. Keela Trennepohl for her help and guidance throughout this research. She was the professor who influenced my decision to pursue a master's degree here at California Polytechnic State University. Through her support and generosity, I could teach courses here at Cal Poly in the Animal Science Department. These teaching experiences have driven my passion into a new direction of pursuing a Ph.D. and teaching at a university. Her generous guidance throughout these years and continued support, even after moving to Illinois, truly shows how dedicated she is to her students. I will always be grateful for what Dr. Trennepohl has taught me and the love of the beef cattle she has instilled in me.

I must extend my sincerest gratitude to my committee members, Dr. David Vagnoni and Dr. Juan Romero, for their support. A special thank you to Dr. Vagnoni for stepping in as my committee chair when Dr. Trennepohl moved. Without Dr. Romero and everyone at his lab at the University of Maine, I would not have been able to complete all the analyses for this project.

The greatest of thanks to Elaina Cromer and Joshua Figg for all their help with this project. They were involved in the preliminary study, treating and ensiling the olive pomace, and counting bacterial colonies. Students from the Nutrition Research Enterprises (2016 - 2017) also helped with many aspects of the project, primarily data input and the digestibility trial.

An even special thank you to my other half, Luis Alvarez, who without his support during this project, all this work would not have been completed. The long and late hours spent planning protocols, mixing and ensiling, running ANKOM machines, and counting microbial plates were all deeply appreciated. I don't know where I would be 
today without the love and compassion he shows in everything he does for me.

I would like to thank the ARI By Product grant for their monetary donation forthe completion of this project and my tuition during my graduate education years. I am also grateful for the services provided by Rock River Labs and Hardy Diagnostics. 


\section{TABLE OF CONTENTS}

Page

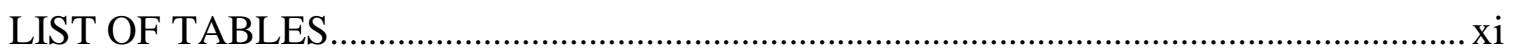

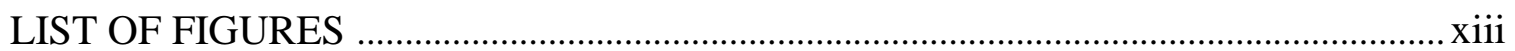

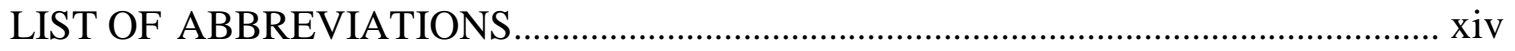

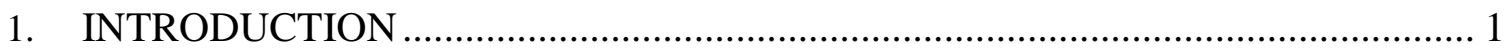

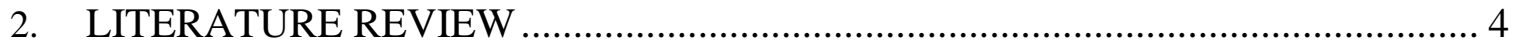

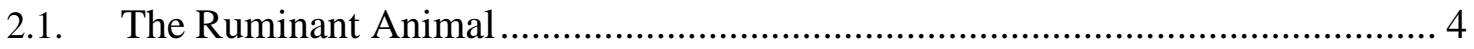

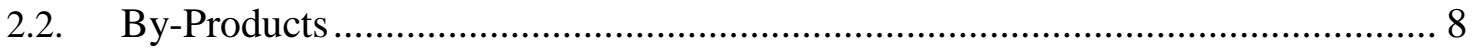

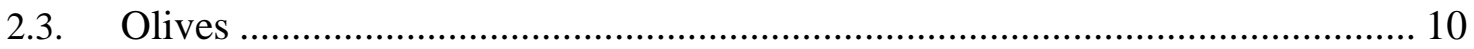

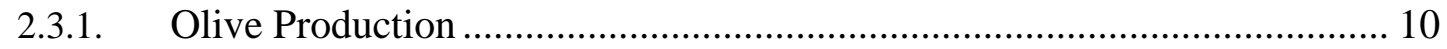

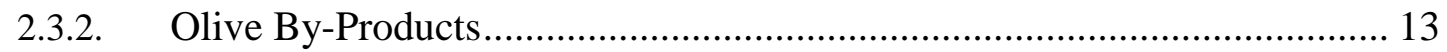

2.3.3. Olive Pomace as a Potential Feed Source............................................... 14

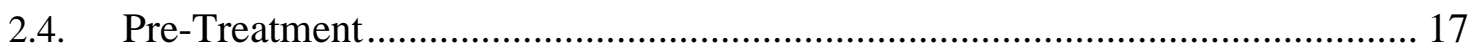

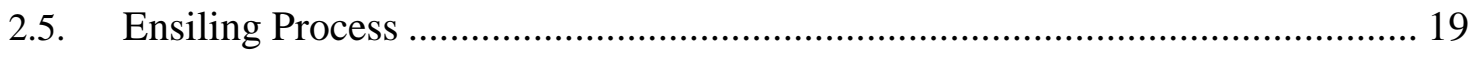

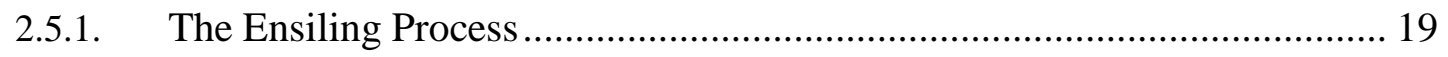

2.5.2. Phase 1 - Aerobic Phase ....................................................................... 20

2.5.3. Phase 2 - Fermentation Phase.............................................................. 21

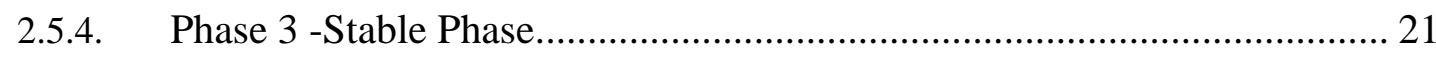

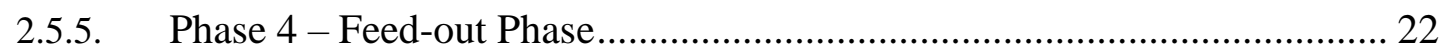

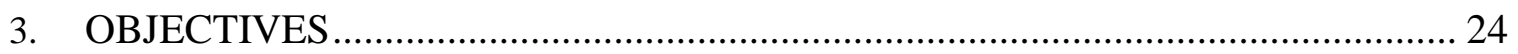

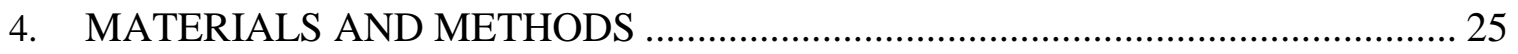




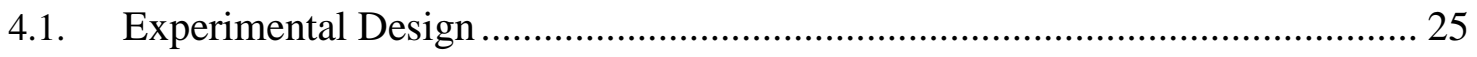

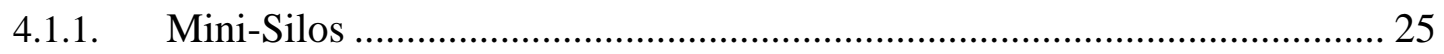

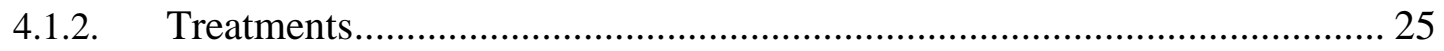

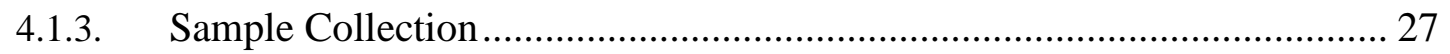

4.2. Chemical Composition ......................................................................... 28

4.2.1. Dry Matter, Organic Matter and Ash ................................................ 28

4.2.2. Neutral Detergent Fiber, Acid Detergent Fiber and Acid Detergent

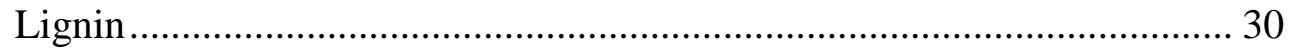

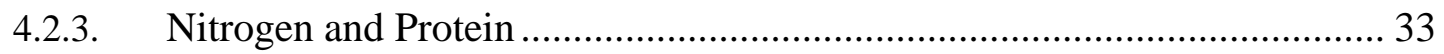

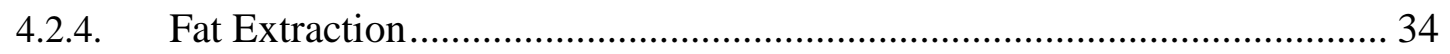

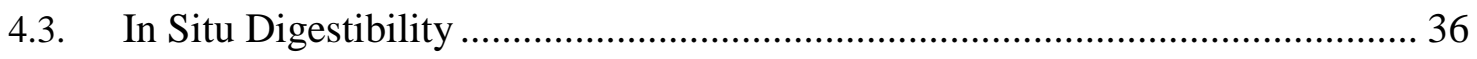

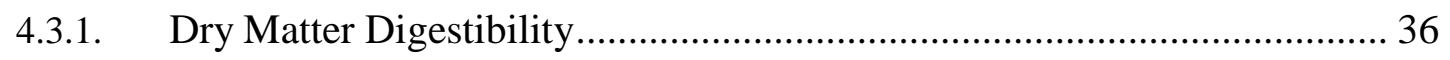

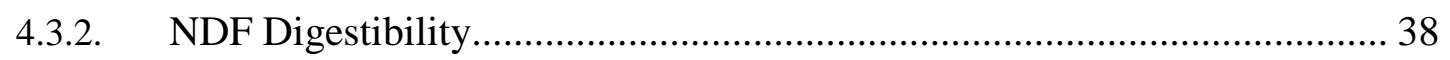

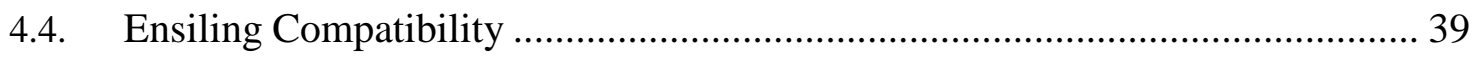

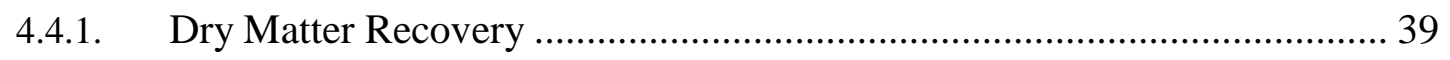

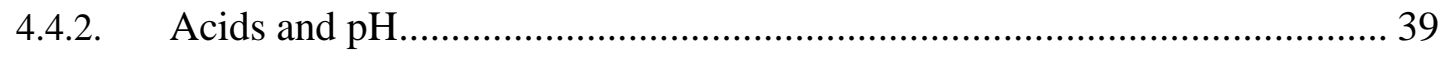

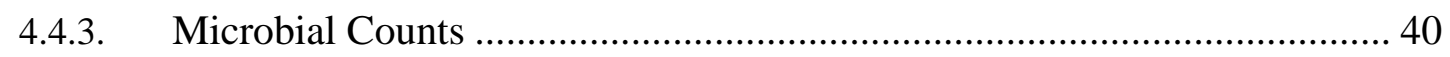

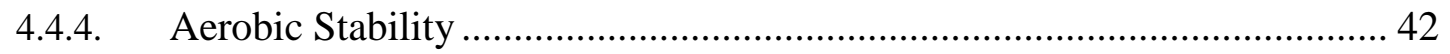

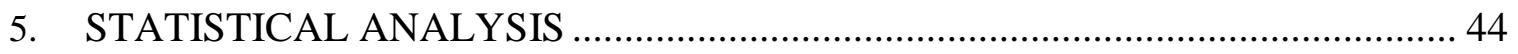

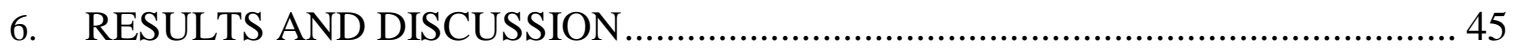

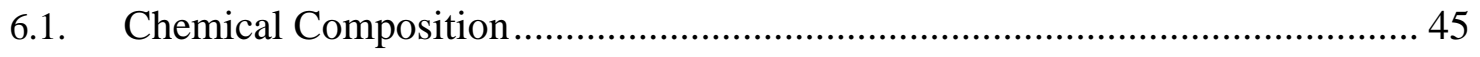

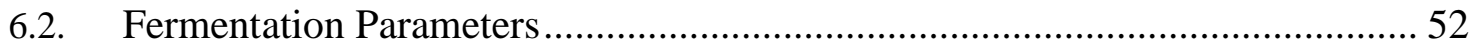


6.2.2. Silage Microbial Populations .................................................................. 59

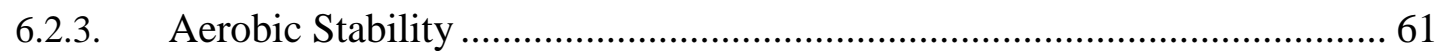

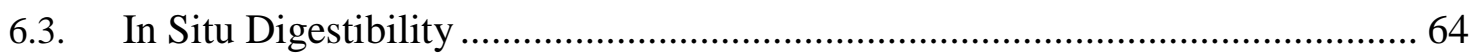

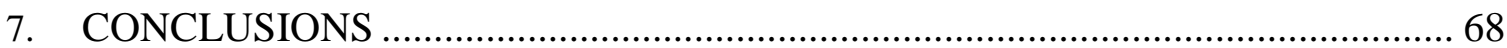

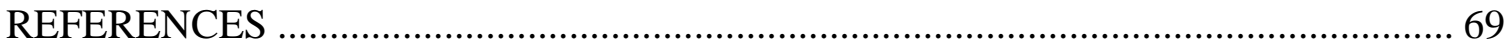


Table

\section{LIST OF TABLES}

1. Average chemical composition ${ }^{1}(\%$ of $\mathrm{DM})$ of commonly used by-products................8

2. Average chemical composition $(\%)$ of olive pomace in literature ..............................15

3. Effects of applying 3 inoculants on mean dry matter (DM, \%) concentration for olive pomace and ensiled for 2, 10, 60, and $120 \mathrm{~d}$

4. Effects of applying 3 inoculants on mean organic matter (OM, \%) concentration for olive pomace and ensiled for 2, 10, 60, and $120 \mathrm{~d}$

5. Effects of applying 3 inoculants on mean ash (\%) concentration for olive pomace and ensiled for $2,10,60$, and $120 \mathrm{~d}$

6. Effects of applying 3 inoculants on mean neutral detergent fiber (NDF, \%) concentration for olive pomace and ensiled for 2, 10, 60, and $120 \mathrm{~d}$

7. Effects of applying 3 inoculants on mean acid detergent lignin (ADL, \%) concentration for olive pomace and ensiled for 2, 10, 60, and $120 \mathrm{~d}$.

8. Effects of applying 3 inoculants on mean acid detergent lignin (ADL, \%) concentration for olive pomace and ensiled for 2, 10, 60, and $120 \mathrm{~d}$

9. Effects of applying 3 inoculants on mean crude protein $(\mathrm{CP}, \%)$ concentration for olive pomace and ensiled for 2, 10, 60, and $120 \mathrm{~d}$

10. Effects of applying 3 inoculants on mean fat (\%) concentration for olive pomace and ensiled for $2,10,60$, and $120 \mathrm{~d}$

11. Effects of applying 3 inoculants on mean water soluble carbohydrates

(WSC, \%) concentration for olive pomace and ensiled for 2, 10, 60, and $120 \mathrm{~d}$

12. Effects of applying 3 inoculants on mean dry matter recovery (DMR, \%) for olive pomace and ensiled for $2,10,60$, and $120 \mathrm{~d}$. 55

13. Effects of applying 3 inoculants on mean $\mathrm{pH}$ for olive pomace and ensiled for $2,10,60$, and $120 \mathrm{~d}$

14. Effects of applying 3 inoculants on mean ethanol concentration for olive pomace and ensiled for $2,10,60$, and $120 \mathrm{~d}$

15. Effects of applying 3 inoculants on mean lactic acid concentration for olive pomace and ensiled for 2, 10, 60, and $120 \mathrm{~d}$

16. Effects of applying 3 inoculants on mean acetic acid concentration for olive pomace and ensiled for 2, 10, 60, and $120 \mathrm{~d}$ 
17. Effects of applying 3 inoculants on mean ammonia-nitrogen (NH3-N, \% of total nitrogen) concentration for olive pomace and ensiled for $2,10,60$, and $120 \mathrm{~d}$.

18. Effects of applying 3 inoculants on mean lactic acid to acetic acid ratio (L:A) for olive pomace and ensiled for 2, 10, 60, and $120 \mathrm{~d}$ 58

19. Effects of applying 3 inoculants on mean homolactic index for olive pomace and ensiled for $2,10,60$, and $120 \mathrm{~d}$

20. Effects of applying 3 inoculants on mean lactic acid bacteria (LAB, log cfu/ $\mathrm{g}$ FM) counts of fresh olive pomace and ensiled for 2, 10, 60, and $120 \mathrm{~d}$

21. Effects of applying 3 inoculants on mean mold (log cfu/g FM) counts of fresh olive pomace and ensiled for 2, 10, 60, and $120 \mathrm{~d}$

22. Effects of applying 3 inoculants on mean yeast (log cfu/g FM) counts of fresh olive pomace and ensiled for 2, 10, 60, and $120 \mathrm{~d}$

23. Dry matter digestibility (DMD, \%), following in situ protocol, of olive pomace treated with 3 inoculants

24. Neutral detergent fiber digestibility (NDFD, \%), following in situ protocol, of olive pomace treated with 3 inoculants 
Figure

\section{LIST OF FIGURES}

1. The passage of feed through the digestive tract of the ruminant animal.......................4

2. Microphotograph of a central transverse section of olive fruit 8 weeks after bloom. At this stage, expansion of the mesocarp (Me) and sclerification of endocarp (En) cells occurs. The locule $(*)$ contains the growing seed. Image credit: Rapoport et al., 2016

3. Olive endocarp cells undergoing sclerification (pit hardening). Top: Formation of lignin-rich secondary wall. Bottom: Wall thickens causing destruction of cell contents. Image credit: Rapoport et al., 2016

4. A schematic comparison of three and two-phase continuous centrifugation systems for the extraction of olive oil. Image credit: Alburquerque, 2004.

5. The general trend of oxygen, $\mathrm{pH}$, and lactic acid bacteria throughout the four phases of the ensiling process: aerobic, anaerobic, stable, and feeding. Image credit: Roth and Undersander, 1995

6. Quartering procedure for representative feed sampling. Adapted from ServiTech Laboratories.

7. Lactobacillus colonies, identified as large in size and of cream color

8. Difference in temperature between ambient and treated olive pomace samples ensiled for $2 \mathrm{~d}$.

9. Difference in temperature between ambient and treated olive pomace samples ensiled for $10 \mathrm{~d}$.

10. Difference in temperature between ambient and treated olive pomace samples ensiled for $60 \mathrm{~d}$.

11. Difference in temperature between ambient and treated olive pomace samples ensiled for $120 \mathrm{~d}$. 


\section{LIST OF ABBREVIATIONS}

ADF

ADL

CP

$\mathrm{DM}$

DMD

LAB

$\mathrm{ME}$

NDF

NDFD

NH3-N

NPN

OL

$\mathrm{OM}$

OMW

OP

OS

SEM

VFAs

WSC
Acid detergent fiber, comprised of cellulose and lignin

Acid detergent lignin

Crude protein

Dry matter, the non-water portion of a sample

Dry matter digestibility, the percentage of DM in a feed that is digested by animals

Lactic acid bacteria

Metabolizable energy

Neutral detergent fiber treated with amylase, comprised of cellulose, hemicellulose and lignin

Neutral detergent fiber digestibility, the percentage of NDF in a feed that is digested by animals

Ammonia-nitrogen

Non-protein nitrogen

Olive leaves

Organic matter

Olive mill wastewater

Olive pomace

Olive stones

Standard error of the mean, the standard deviation of a distribution statistic

Volatile fatty acids, acetate, butyrate, and propionate

Water soluble carbohydrates 


\section{INTRODUCTION}

Feed costs represent $70 \%$ of cow-calf cattle production costs and are a critical factor in determining profitability within all livestock operations (Miller et al, 2001). Ruminant animals have a unique and complex digestive system that enables them to consume fiber and convert it into energy through microbial digestion (Van Soest, 1994). Due to their ability to utilize fiber, forages are a primary feed source for ruminants, yet many contain lessened nutritional value when compared to concentrates such as corn and barley (Van Soest, 1994). Certain by-products such as those from milling, brewing, and harvesting operations fall under the same circumstances due to their high fiber concentration (Garcia et al., 2005; Christodoulou et al., 2008). An advantage to feeding by-products to ruminants is the reduction in waste management costs for food processors and a decreased reliance on grains as supplements (Grasser et al., 1995). Therefore, new by-products are highly sought after, and research targets ways of improving their application into ruminant feeds.

The olive (Olea europaea L.) and its oil content are worldwide popular edible products with foreseeable production growth in the general United States (International Olive Oil Council) and California (California Olive Oil Council). Many by-products are generated from the production of olive oil; olive leaves, olive stones, olive milling wastewater, and olive pomace. Olive pomace typically consists of all the "waste" products derived from the two-phase centrifugation processes of olive oil, making up approximately $80 \%$ of the original product weight (Alburquerque, 2004). Components include olive skin, pulp, stone and water. Like many by-products, olive pomace can be variable in its nutritional profile. Olive pomace (OP) has shown to be an acidic and very wet product, 
high in fat content and energy, and containing adequate levels of crude protein and variable $\mathrm{NDF}, \mathrm{ADF}$, and ADL due to variation in the proportion of stones that contribute to high lignocellulolytic content (Alburquerque, 2004).

With low nutrient content and a need for storage, OP is a prime candidate for pretreatment and ensiling to improve its nutrient profile for potential use in cattle feeds. Ensiling is a preservation method commonly used for high moisture forages. The primary basis of the ensiling process is the conversion of water soluble carbohydrates (WSC) into organic acids, primarily lactic acid, by lactic acid bacteria under anaerobic conditions. With acid production, the $\mathrm{pH}$ decreases, undesirable microorganisms are suppressed, and the product reaches a phase where it can remain stable for up to a 1 year without exposure to oxygen. Homofermentative lactic acid bacteria (LAB) can be added to ensiled forages to dominate fermentation to lactic acid for a quicker pH drop (Kung Jr., 2011). With lower concentrations of crude protein, OP can be combined with an inexpensive non-protein nitrogen source such as urea to improve the nutritional value (Kung Jr., 2003). Alkali treatment such as calcium oxide and calcium hydroxide are commonly used additives in livestock feeds because they are readily available and inexpensive. Treating lignocellulosic substances with alkali causes numerous molecular actions that disrupt the integrity of the cell wall: hemicellulose, lignin and silica dissolve, hydrolysis of uronic and acetic acid esters occur, and cellulose swells causing a decrease in its crystallinity (Jackson, 1977).

Current research is focused on the effects of these inoculants in sugarcane, corn, and grass silages. The objectives of this study were (1) to determine the effects of chemical (urea and calcium oxide) and bacteria (lactic acid bacteria) inoculants in combination with 
ensiling, on the nutritional value and ensiling compatibility of olive pomace and (2) to identify the most biologically favorable treatment and ensiling day of olive pomace for feeding to cattle. 


\section{LITERATURE REVIEW}

\subsection{The Ruminant Animal}

The ruminant animal has a specialized digestive tract for the breakdown of high fiber feedstuffs, such as forages and high-fiber by-products, into nutrients for animal maintenance, production, and reproduction (Church, 1993). The unique digestive tract of ruminants begins with the head gut that contains a dental pad in place of incisors that allows for better apprehension of forages. The midgut of cattle consists of a four-chambered stomach, containing a reticulum, rumen, omasum, and abomasum developed over timefor optimal roughage digestion. Figure 1 diagrams the passage of feed through a ruminant digestive tract. The reticulum is the foremost chamber of the stomach, and closest to the heart. Its honeycomb shaped tissues are efficient at collecting heavy or dense feed and foreign objects. A small tissue fold lies between the reticulum and rumen, yet the two are not considered separate compartments. Instead they are called the rumino-reticulum (Church, 1993).

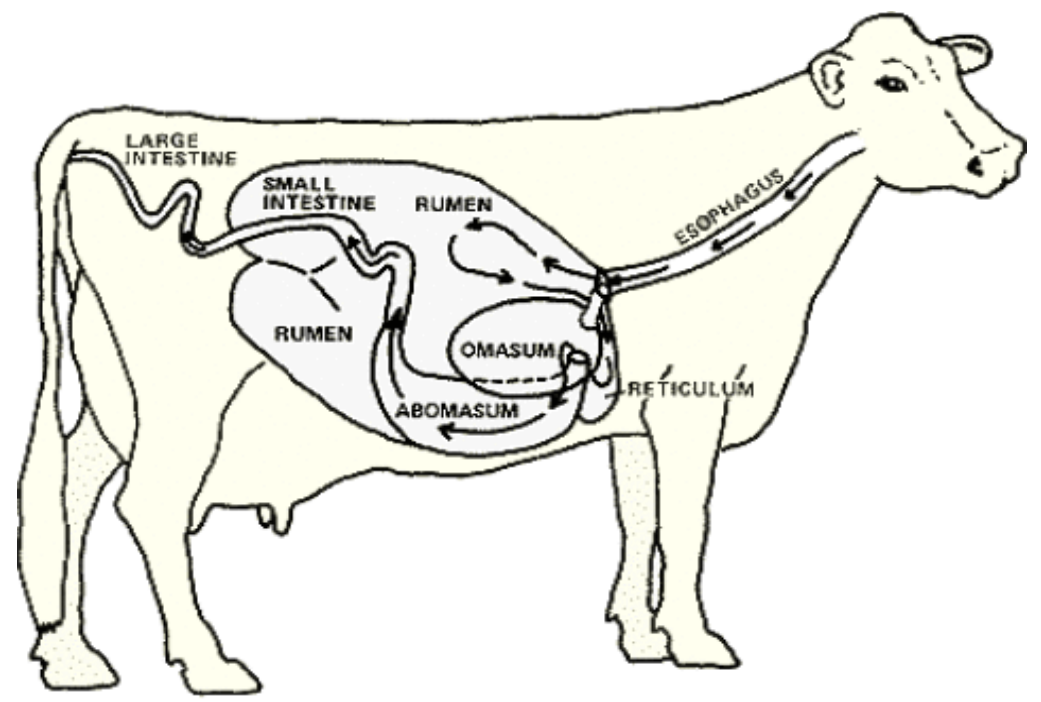

Figure 1: The passage of feed through the digestive tract of the ruminant animal. 
The rumen is the largest stomach compartment, consisting of multiple sacs, and due to its size, is used as a storage vat for feed. It contracts and moves continuously at a rate of one to two rumen contractions per minute, mixing, bringing microbes into contact of new feedstuffs, reducing flotation of solids, and moving materials out of the rumen. By ruminating, cud can be regurgitated into the mouth where it is re-chewed and broken into smaller pieces. Doing this and re-salivating, feed is made more readily available for fermentation; the single most important process that takes place in the chamber. Microbes thrive in the rumen due to its favorable environment that provides carbohydrates, ammonia and amino acids for fermentation. Storage and soluble carbohydrates are fermented at a quicker rate than structural carbohydrates. Rumen bacteria that digest structural carbohydrates (cellulose and hemicellulose) produce acetic acid but are very sensitive to rumen acidity and high fat levels. When a feed contains too much fat, cellulose-digesting bacteria are destroyed, and their growth suppressed which in turn reduces the rumen digestibility of the feed. Starch-digesting bacteria rapidly ferment starch and produce lactic and propionic acid. Excess fermentation of starches increases the acidity of the rumen, negatively effecting the cellulose-digesting bacteria (Moran, 2005). Similar bacteria digest soluble sugars and produce propionate. Rumen microbes produce gases (methane and carbon dioxide) and volatile fatty acids from the breakdown of simple and complex carbohydrates in the feed. Volatile fatty acids (VFAs) provide 50 to 70 percent of the cattle's energy, mostly made up of acetic, propionic, and butyric acids (Bergman, 1990). These VFAs are then absorbed through the ruminal wall by papillae - tiny projections that line the rumen and increase its surface area, therefore also increasing the amount of VFAs that can be absorbed. Through fermentation, protein is also broken down and converted 
into ammonia, organic acids, amino acids and other products, with about 40 to 75 percent of the natural protein degraded in the rumen (Church, 1993). Two major lipid metabolism processes occur in the rumen, the hydrolysis of ester linkages and the biohydrogenation of unsaturated fatty acids. Bacteria involved in hydrolysis produce lipase and esterase which hydrolyze glycerols and esters, respectively. Isomerase is involved in forming a trans-11 bond in the fatty acid followed by hydrogenation by reductase (Jenkins, 1993).

The omasum is globe-shaped containing leaves of tissue to help aid in the absorption of water and other substances from digestive contents. The abomasum is similar to a nonruminant stomach and contains glands that release hydrochloric acid and digestive enzymes for further breakdown of feed and absorption of microbial protein (Linn et al., 2018).

From the four-chambered stomach, feed is transferred into the small intestine. It consists of the duodenum, jejunum, and ileum, together measuring about 20 times the length of the animal (Church, 1993). The small intestine is where most of the digestive process for fat is completed by pancreatic and gallbladder secretions, with nutrients absorbed through the lymphatic systems and villi in the bloodstream. Microbial protein that passes through the rumen and abomasum is also absorbed here. The remaining portion of the digestive tract includes the cecum, colon and rectum, collectively referred to as the large intestine. The primary role of this organ is water absorption of the passing material; most water absorption occurs in the colon. Bacteria are able to further digest material that preluded digestion earlier in the tract. The cecum is where some previously undigested fiber can be broken down, but it serves little function compared to its role in horses (Parish et al., 2017). Undigested feed and metabolic waste exit the animal through the rectum as manure. 
The nutritional composition of a diet can have varying effects on the digestibility and absorption of the nutrients by the animal. High forage diets allow for more acetic acid formation (60 to 70 percent of total) compared to propionic and butyric acids (15 to 20 percent and 5 to 15 percent respectively). Diets that have more grain or finely ground roughage can lower the acetic acid concentration to 40 percent, while propionic acid can increase to 40 percent (Linn et al., 2018). Protein breakdown can depend on multiple factors including its ability to dissolve, how resistant it is to breakdown, and how fast feed can pass through the rumen. Nonprotein nitrogen (NPN) sources are also capable of providing ammonia. These include urea, ammonium salts, nitrates, and other compounds. Because most rumen microbes need ammonia to grow and build protein, ammonia is necessary for microbial fermentation, and supplementing RDP in feeds can aid in optimizing microbial function (Church, 1993). Cattle absorb more saturated fat than monogastric animals due to rumen microbes converting unsaturated fatty acids to saturated fatty acids through the addition of hydrogen molecules. Feeding high amounts of unsaturated fatty acids can be toxic to ruminal bacteria, leading to slower fiber digestion (Moran, 2005).

The original natural diet of cattle consisted of grasses, stems, and other herbaceous plant materials, with an average consumption of $65.5 \mathrm{~kg}$ of fresh grass per day (Field et al. 2011), but today commercial producers feed rations that can contain feedstuffs such as corn, soybean meal, blends of forages, and supplements to meet the extensive nutritional needs of the animal (Lalman and Sewell, 1993). Grains are widely utilized for their high energy properties in growing and finishing cattle, yet the prices of grains have increased dramatically, especially that of corn, which is averaging about $\$ 180$ per ton as of May 2018 
(Index Mundi, 2018) due to its increased use in ethanol production. The need for high energy feedstuffs is essential for growing and finishing cattle, therefore by-products are an important component in balancing feed rations and costs.

\subsection{By-Products}

By-products are products usually derived in addition to the principal product from industrial or biological processes, such as milling and fermentation of grains, manufacturing of dairy products, processing of oilseeds, and the slaughter of animals. The use of by-products in livestock feeds is well established and substantial research has been conducted on most by-product feeds (Stern and Ziemer, 1995; Azevedo et al., 2012; Bernard, 2017). Commonly incorporated by-products in ruminant rations are described below and the average chemical composition is reported in Table 1.

Table 1: Average chemical composition ${ }^{1}$ (\% of DM) of commonly used by-products

\begin{tabular}{lcccc}
\hline Nutrient & $\mathrm{CGF}^{2}$ & $\mathrm{CS}^{3}$ & $\mathrm{DDG}^{4}$ & $\mathrm{BG}^{5}$ \\
\hline Dry matter & 88.3 & 92.9 & 89 & 91 \\
Ash & 6.9 & 6.6 & 5.4 & 4.6 \\
Ether Extract & 3.4 & 0.6 & 11.1 & 6.7 \\
Gross Energy (MJ/kg dry matter) & 18.8 & 17.9 & 21.4 & 19.7 \\
Crude protein & 21.7 & 3.7 & 29.5 & 25.8 \\
Neutral detergent fiber & 39.6 & 82.4 & 34.2 & 56.3 \\
Acid detergent fiber & 10.6 & 53.2 & 13.6 & 21.9 \\
Acid detergent lignin & 1.2 & 8.4 & 4.3 & 5.4 \\
\hline$\quad{ }^{1}$ Source: Heuze et al., 2015a, 2015b, 2016, and 2017 & & & \\
$\quad{ }^{2}$ CGF: Corn gluten feed & & & & \\
$\quad{ }^{3}$ CS: Corn Stover \\
$\quad{ }^{5}$ BG: Brewers grains
\end{tabular}


Processing of cereal grains generates by-products with higher protein, fiber and fat levels than the original product. Corn gluten feed (CGF) is a bran portion by-product from the wet-milling process of corn. A typical ration of CGF has higher concentration of proteins and phosphorus. CGF is commonly used as a protein supplement for beef cattle (Trenkle et al., 1989; Scott et al., 1997) due to its high protein concentration (Table 1). Corn stover is another by-product originating from the harvesting process of corn. This can be a palatable product for beef cattle (Clark et al., 2013; Li et al., 2014; Meeter et al., 2018) but when high amounts of stalks are present, it has shown to reduce dry matter intake (Gould, 2011).

From the fermentation of grains for alcohol production, remains the stillage which is commonly separated into distiller's grains. Distiller's grains can be fed as a wet or dry product and either alone or with solubles. These by-products have higher fat, fiber, protein, and vitamins than the primary product (Ellis and Bird, 1951), making them highly valuable for feeding cattle. Adding dried distiller's grains (DDG) to high forage diets allows for higher forage digestion due to the lower concentrations of starch present compared to starch concentrations commonly found in corn (Loy et al., 2007.). Brewing barley also produces the by-products brewer's dried grains, malt sprout, and brewer's dried yeast. Brewer's grains are a relatively good source of rumen by-pass protein, but typically have less energy and slightly greater calcium concentrations than whole grains (Rogers et al., 1985; Alawa et al., 1988). Dried grains and dried grains with solubles have been extensively applied in cattle and sheep rations (Gibb et al., 2008; Gunn et al., 2009).

The processing of plants and fruits generates pulps, pomaces and additional residue components that are usually high in fiber and produced in large quantities. The pulp and 
pomace (peel, seed and pulp) from citrus, apples, and tomatoes can be fed wet or dry to ruminants (Kennedy et al., 1999; Bampidis and Robinson, 2005), with successful applications when ensiled (Denek and Can, 2006; Abdollahzadeh et al., 2010).

New by-products are highly sought after and research targets ways of improving their application into ruminant feeds. Depending on the intrinsic variability of a by-product, nutritional analysis should be done ideally every time a new batch is purchased. This will reduce the probability of under or overfeeding animals and the consequent economic losses to livestock producers.

\subsection{Olives}

\subsubsection{Olive Production}

The olive (Olea europaea L.) and its oil content have become worldwide popular edible products with many known and predicted nutritional benefits. Olive tree cultivation has steadily increased from 2,608,804 ha in 1961 to 10,650,068 ha in 2016 with olives almost doubling in production (8,205,586 tonnes and 19,267,493 tonnes, respectively) (Food and Agriculture Organization). Spain (46.5\%), Italy (11.8\%), and Greece (8.3\%) accounted for almost 67\% of the world's olive oil production from 2013/2014 to 2016/2017 (International Olive Oil Council). Although only accounting for $0.4 \%$ in recent years, the United States has seen a $1,050 \%$ increase in olive oil production in the past decade (International Olive Oil Council) and is expected to continue increasing production in the coming years. In California, over 40,000 acres are designated for olive tree cultivation with an estimated addition of 20,000 new acres every year (California Olive Oil Council). With 3.5 million gallons produced in 2016 and an estimated 4.3 million in 2017 (California Olive Oil 
Council), olive oil production in California is a growing agricultural market.

The olive fruit contains three principal tissues: the epi or exocarp, mesocarp, and endocarp. The exocarp refers to the external fruit tissue which envelops the mesocarp, or fruit pulp. The pulp is the major edible portion of the fruit where oil biosynthesis and storage occur (Connor and Fereres, 2005; Rapoport et al., 2016). At the center of the pulp is the endocarp, stone or pit, of the fruit (Figure 2). This tissue undergoes rapid growth at the onset of fruit development followed by the cell differentiation process of sclerification (Figure 3). During this process synthesis and deposition of lignin form a secondary wall which eventually fills the entire cell, destroying its contents (Hammami et al, 2013; Rapoport et al., 2016). Cell sclerification and thickening continues, contributing to the dry weight increase of the tissue (Rapoport et al., 2016).

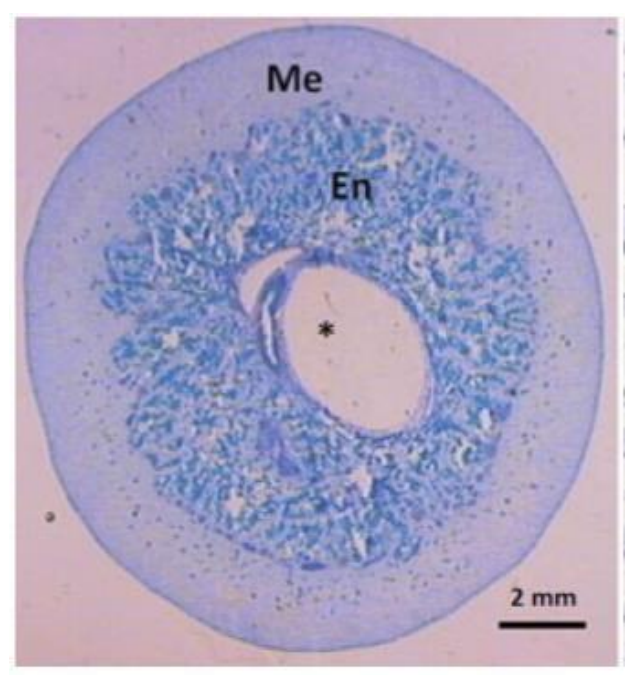

Figure 2: Microphotograph of a central transverse section of olive fruit 8 weeks after bloom. At this stage, expansion of the mesocarp (Me) and sclerification of endocarp (En) cells occurs. The locule (*) contains the growing seed. Image credit: Rapoport et al., 2016. 


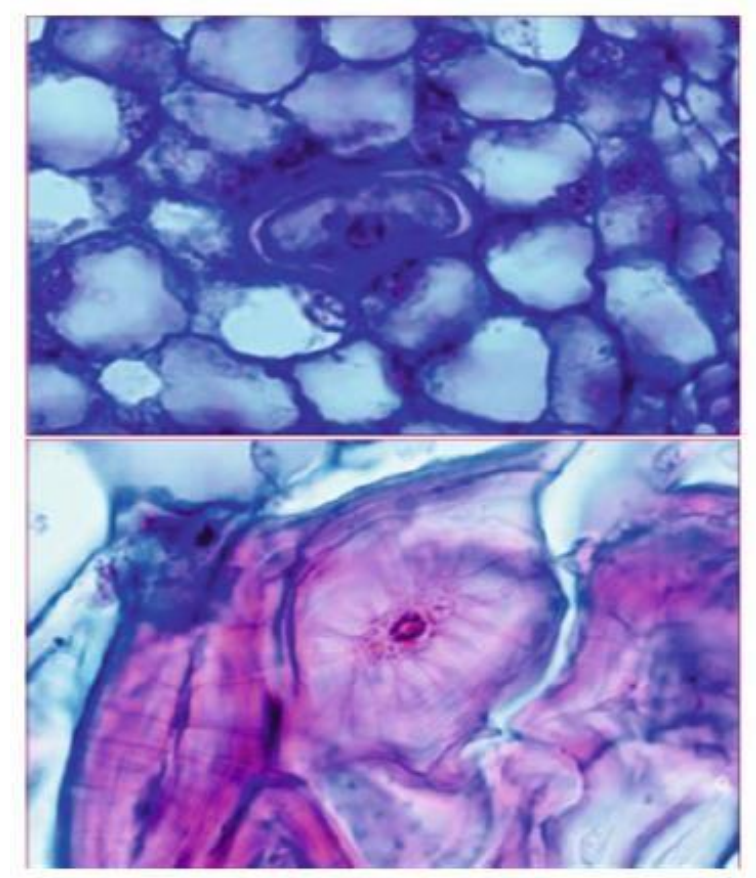

Figure 3: Olive endocarp cells undergoing sclerification (pit hardening). Top: Formation of lignin-rich secondary wall. Bottom: Wall thickens causing destruction of cell contents. Image credit: Rapoport et al., 2016

No matter the type of system, making olive oil requires the same basic steps: olive washing, milling and beating, centrifugation, and oil washing. Two types of continuous centrifugation procedures have been commercially recognized and differences in their resulting by-products have been documented and illustrated by Alburquerque, 2004 (Figure 4). The three-phase continuous centrifugation system, adapted in the early seventies, separates the product into oil (20\%), a solid residue (30\%), and an aqueous phase known as olive mill wastewater (OMWW) (50\%) (PROSODOL). During the centrifugation step, a significant amount of hot water is added to wash the oil. A solid residue comprising of olive pulp and stones is removed leaving two liquid phases which go through vertical centrifugation to separate the oil from the waste water. The two-phase continuous centrifugation system goes through horizontal centrifugation without the addition of hot 
water resulting in a very wet solid phase and the oil phase which continues through to vertical centrifugation for the washing of the oil. With less water and energy used, the twophase system is the most widely used continuous centrifugation system for olive oil extraction.

Three-phase

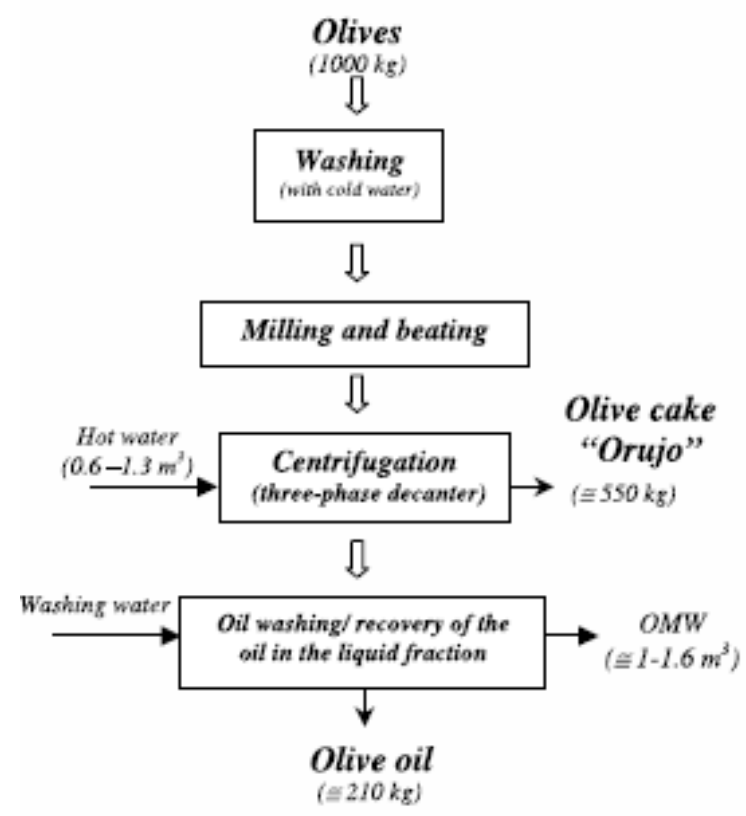

Two-phase

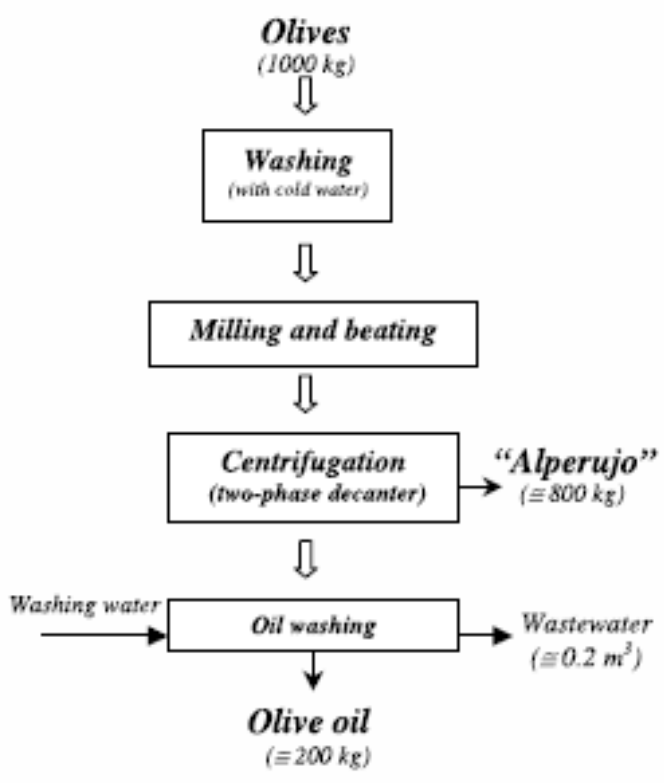

Figure 4: A schematic comparison of three and two-phase continuous centrifugation systems for the extraction of olive oil. Image credit: Alburquerque, 2004

\subsubsection{Olive By-Products}

The following products are commonly known as "olive by-products". These olive byproducts originate from olive trees and the extraction processes of olive oil.

Olive leaves (OL) is a term referring to the leaves and branches from two different processes of production. The majority of this product originates from the harvesting and cleaning of olives before they are subjected to oil extraction; accounting for approximately 
$5 \%$ of the total weight of olives processed (Sesli and Yeğenoğlu, 2009). Some of this product is also collected from the pruning of the olive trees. OL have shown to improve the concentration of tocopherol in meat when added into in pig diets at $25 \mathrm{~g} / \mathrm{kg}$ (PaivaMartins et al., 2014). The olive stones (OS) and the milling wastewater (OMW) are other by-products derived from the centrifugation process that can be utilized in animal feeds.

Olive pomace (OP), also referred to as olive cake, typically consists of all the "waste" products derived from the horizontal centrifugation processes of olive oil. These components include olive skin, pulp, stone and water. Olive pomace may be further categorized based on its oil content (crude or exhausted), moisture (fresh or dry), or stone removal. Both types of centrifugation extraction procedures result in a form of this byproduct. The main difference is observed in the moisture and oil content of the OP, with two-phase OP containing lower oil and higher moisture concentration than the three-phase OP (Alburquerque, 2004). As seen in Figure 4, of the initial weight of olives, approximately $80 \%$ and $55 \%$ is generated into OP from the three and two-phase procedures, respectively (Alburquerque, 2004).

\subsubsection{Olive Pomace as a Potential Feed Source}

Currently, the uses for olive pomace (OP) are limited; with increasing olive oil production, the need for an alternative use is highly demanded. The table below (Table 2) reports the average chemical composition of OP from the literature. 
Table 2: Average chemical composition (\%) of olive pomace in literature

\begin{tabular}{|c|c|c|}
\hline Nutrient & $\mathrm{OP}^{1}$ & $\mathrm{SD}^{2}$ \\
\hline Dry matter & $43.0^{\mathrm{B}, \mathrm{C}, \mathrm{F}, \mathrm{G}, \mathrm{J}, \mathrm{L}}$ & 8.77 \\
\hline Organic matter & 89.8 A-C, E, F, H-M & 4.05 \\
\hline Ash & $6.26^{\mathrm{B}, \mathrm{D}, \mathrm{G}, \mathrm{K}, \mathrm{M}}$ & 5.62 \\
\hline Ether Extract & $12.4^{\mathrm{A}, \mathrm{E}-\mathrm{G}, \mathrm{K}, \mathrm{M}}$ & 6.01 \\
\hline Gross Energy (MJ/kg dry matter) & $18.7^{\mathrm{H}, \mathrm{I}}$ & 0 \\
\hline Crude protein & $6.8^{\mathrm{A}, \mathrm{B}, \mathrm{D}-\mathrm{H}, \mathrm{J}-\mathrm{M}}$ & 1.41 \\
\hline Neutral detergent fiber & $64.3^{\mathrm{A}, \mathrm{D}-\mathrm{K}, \mathrm{M}}$ & 8.76 \\
\hline Acid detergent fiber & $50.6^{\mathrm{A}, \mathrm{D}-\mathrm{K}, \mathrm{M}}$ & 8.10 \\
\hline Acid detergent lignin & $30.0^{\mathrm{A}, \mathrm{G}-\mathrm{K}, \mathrm{M}}$ & 4.91 \\
\hline Crude Fat & $7.42^{\mathrm{D}, \mathrm{H}-\mathrm{J}}$ & 3.56 \\
\hline 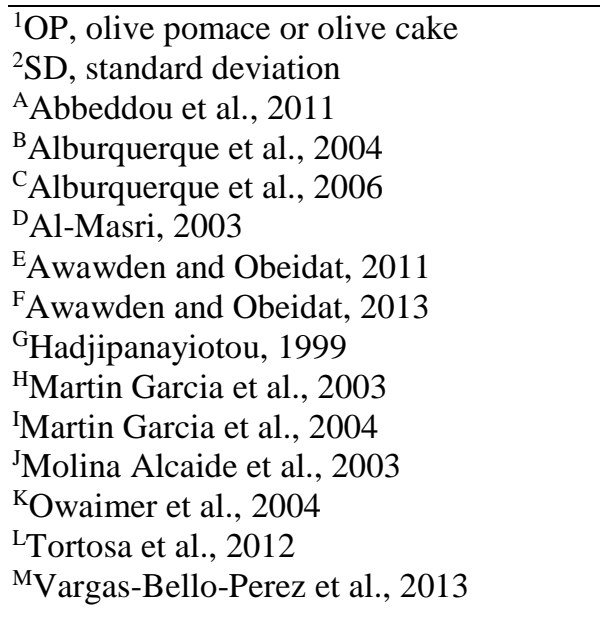 & & \\
\hline
\end{tabular}

The large variability in the chemical composition of OP (Table 2) can be attributed to many factors which include: differences in the physical components (skin, pulp, stone, and water), year of production, geographical region, residual oil extraction, soil contamination, and type of centrifugation. Dry matter (DM) concentration of OP is low and variable (34.1 to $64.1 \%$ ). The energy portion of the product is high at $18.7 \mathrm{MJ} / \mathrm{kg} \mathrm{DM}$ (Martin Garcia et al., 2003 and 2004). Crude protein concentration of the product is not great, averaging $6.8 \%$; crude fat concentration is high as expected due to the origin of the product. Variability was observed in the fiber components NDF, ADF, and ADL, presumably due 
to the variation of the proportion of stones in the $\mathrm{OC}$, since they contribute to high lignocellulolytic concentration.

OP is not easily digested by ruminants (Al-Masri 2003; Owaimer et al., 2004) and studies have found inclusion of it into the rumen causes a $40 \%$ decrease in rumen microflora activity (Theriez and Boule, 1970) when measured by gas release. According to the Food and Agriculture Organization (FAO), there are three potential reasonings that may explain these results. Total dietary fat concentrations should not exceed 5\% of DM due to the negative effects on the rumen microflora (Moran, 2005). The nature of the fatty acids and the quantity play a large role in influencing the rumen microflora, shifting of which can cause decreased fiber digestibility (Van Nevel and Demeyer, 1988). Inhibiting factors such as phenols and tannins have also been known to insolubilize proteins preventing digestion (McSweeney et al., 2001; Molina Alcaide et al., 2003). Molina Alcaide et al. (2003) reported an average of $0.59 \mathrm{~g} / 100 \mathrm{~g}$ FM of protein-bound tannins in two-phase olive cake and potential CP degradability in the rumen was high $(\sim 78 \%$ across two seasons of harvest). The last possible explanation is the influence of lignin, which is resistant to bacterial and fungal degradation. Since olive pomace has a very high concentration of lignin (Molina Alcaide and Nefzaoui, 1996), a lesser concentration of the total product is available for ruminal digestion. Studies have shown that including additives to the olive pomace can potentially improve certain nutrient aspects and digestibility of the product. 


\subsection{Pre-treatment}

With a low protein concentration, olive pomace would not be considered as a potential protein supplement for ruminant diets. A common practice for improving the protein concentration of a feed is through the addition of a non-protein nitrogen (NPN) source such as urea. Studies have shown the addition of urea to olive pomace to successfully improve crude protein concentration (Owaimer et al., 2004; Rowghani et al., 2008). When olive pomace was ensiled with $0.5 \%$ urea, $0.4 \%$ formic acid, and $8 \%$ molasses, an increase of $25 \% \mathrm{DM}, 28 \% \mathrm{CP}$, and $1.71 \% \mathrm{NH}_{3} \mathrm{~N}$ levels were observed when compared to non-treated olive pomace (Rowghani et al., 2008).

Alkali treatment such as calcium oxide and calcium hydroxide are commonly used additives in livestock feeds because they are readily available and inexpensive. Calcium oxide $(\mathrm{CaO}$, molar mass $=56 \mathrm{~g} / \mathrm{mol})$ is an inorganic material rich in calcium that when combined with water, produced a strong alkali, calcium hydroxide $\left(\mathrm{Ca}(\mathrm{OH})_{2}\right.$, molar mass $=74 \mathrm{~g} / \mathrm{mol}$ ). Treating lignocellulosic substances with alkali causes numerous molecular actions that disrupt the integrity of the cell wall: hemicellulose, lignin and silica dissolve, hydrolysis of uronic and acetic acid esters occur, and cellulose swells causing a decrease in its crystallinity (Jackson, 1977). Bonds between lignin and hemicellulose are cleaved, making the cell wall more capable of biodegradability (Li et al., 2014). These mechanisms of action allow for more bacterial adhesion to the cell wall contents, consequentially increasing fiber degradation.

A meta-analysis studying the effects of $\mathrm{CaO}$ addition on the preservation of sugarcane silage was performed by Jacovaci et al., 2017. The analysis found the use of $\mathrm{CaO}$ to be associated with decreased ethanol and propionic acid production, improved dry matter 
recovery (DMR), increased ammonia-nitrogen $\left(\mathrm{NH}_{3}-\mathrm{N}\right)$ and lactic acid, improved aerobic stability, and no effect on yeast counts. $\mathrm{CaO}$ addition also greatly increased the $\mathrm{pH}$ of the product and showed to be resistant to $\mathrm{pH}$ drop during fermentation; stimulation of lactic acid production followed in sugarcane silage (Jacovaci et al., 2017) as well as in other silages (Owens et al., 1969; Heinrichs and Conrad, 1984). Looking at the chemical composition of the sugarcane silages, $\mathrm{CaO}$ addition showed significant increases in DM, ash and in vitro DM digestibility but lowered crude protein $(\mathrm{CP})$ and fiber concentrations (Jacovaci et al., 2017). Klopfenstein (1978) reported that the addition of CaO improved neutral detergent fiber digestibility (NDFD) in different roughages; dried corn distillers grains (DDGS) and corn stover treated with alkaline agents improved digestibility of the product in cattle (Felix et al., 2012 and Shi et al., 2015). Others found the addition of an alkali treatment to increase the neutral detergent fiber (NDF) of corn stover (Cook et al., 2016) and the potentially digestible NDF of wheat straw (Haddad et al., 1994) with no effects to the rate of digestion. Treating olive pomace with $\mathrm{NH}_{4} \mathrm{OH}$ or $\mathrm{NaOH}$ reduced NDF, $\mathrm{ADF}$, and ADL concentrations (14 and 26, 13 and 18, and 8 and 15\%, respectively) (Nefzaoui and Vanbelle, 1986); similar to findings for Owaimer et al., 2003.

Variability in many of the effects of bacteria and chemical treatments on different forages and particularly silages is found throughout the literature, even more so for byproducts. Applying similar pre-treatments to olive pomace can potentially improve the nutrient profile of the product, making it more practical and applicable for cattle consumption. 


\subsection{Ensiling Process}

The seasonality of olive by-product production makes them difficult to be incorporated into animal feeding throughout the year unless proper preservation and storage methods are applied. Olive leaves (OL) can be dried and incorporated into feed rations with proper treatment to combat the high lignin concentration but provide very little in terms of their nutritional profile. Unlike OL, crude olive pomace (OP) contains high levels of water and oil. Proper storage is essential for prolonging the use of the product. Ensiling has been regularly reported as a simple, yet effective procedure performed on many feedstuffs to prolong the life of the product, and research has shown it to be effective on OP alone or with the addition of additives or other feedstuffs (Hadjipanayiotou 1994; Rowghai et al., 2008; Arco-Perez, 2017).

\subsubsection{The Ensiling Process}

Ensiling is a form of preservation commonly used for high moisture feedstuffs (Weinberg and Chen, 2013). The ensiling process is an anaerobic process characterized by the conversion of water-soluble carbohydrates into organic acids bylactic acid bacteria (LAB) (Weinberg and Chen, 2013; Kraut-Cohen et al., 2016), which cause a decrease in silage $\mathrm{pH}$. The ensiled moist crops, now referred to as silage, go through acidification due to the accumulation of lactic acid and remain in a stable preservation state until exposed to oxygen (Kraut-Cohen et al., 2016). Due to its stable state, proper ensiling allows for longterm storage of forages (Pahlow et al., 2003; Duniere at al., 2013). To properly produce silage of high quality, the effects of the chemical and biological processes on the silage must be recognized. 
The ensiling process was originally partitioned by Barnett (1954) into four main phases: aerobic, fermentation (anaerobic), stable, and feed-out (feeding) phase. The phases were then detailed and refined by Zimmer (1969) and Weinberg and Muck (1996), respectively (Pahlow et al., 2003). The general trends throughout the ensiling process can be observed in Figure 5 below. The $\mathrm{pH}$ of the silage will remain constant until it reaches a sharp decrease during the fermentation phase also where bacterial populations will be at their highest.

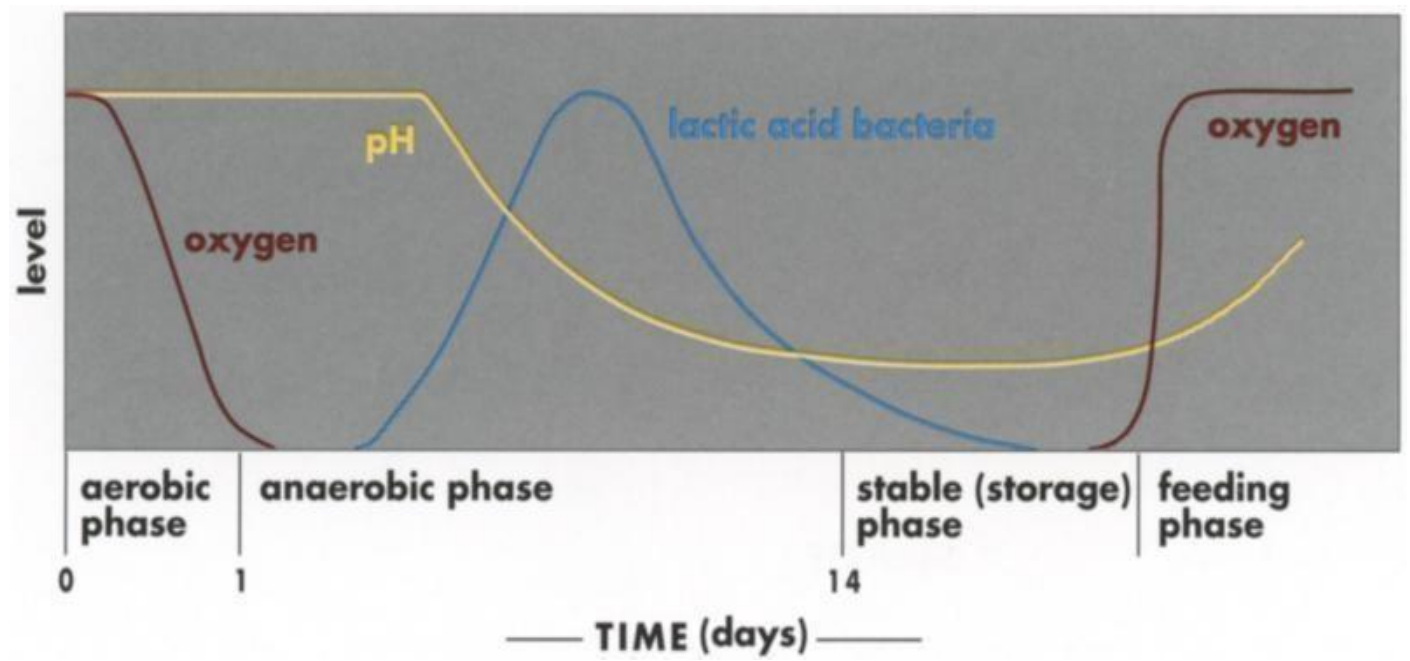

Figure 5: The general trend of oxygen, $\mathrm{pH}$, and lactic acid bacteria throughout the four phases of the ensiling process: aerobic, anaerobic, stable, and feeding. Image credit: Roth and Undersander, 1995

\subsubsection{Phase 1 - Aerobic Phase}

The aerobic phase generally lasts a few hours and is mainly characterized by the steady decrease in atmospheric oxygen with little to no change in $\mathrm{pH}$ (Figure 5). Plant and microbial respiration is maintained by the amount of oxygen trapped between fiber particles (Pahlow et al., 2003; Weinberg and Chen, 2013). Respiration uses the forage 
sugars and trapped oxygen to release carbon dioxide, water and heat (Nadeau and Barnhart, 2008). Plant enzymes remain active during this phase as proteases start the breakdown of proteins into soluble non-protein nitrogen (NPN) (Nadeau and Barnhart, 2008) and carbohydrase form additional highly digestible soluble carbohydrates (Pahlow et al., 2003), which become available for fermentation. Lactic acid bacteria (LAB) populations are almost rare during this phase since soluble carbohydrates are primarily utilized by the plant enzymes, acetic acid bacteria, and fungi (Pahlow et al., 2003).

\subsubsection{Phase 2 - Fermentation Phase}

The fermentation phase commences once all the trapped oxygen has been depleted from the silo. Depending on the conditions of the ensiled crop, this phase can last between 1 week and 1 month. Microbial populations at this stage are dominated by LAB such as Lactobacillus, Pediococcus, Leuconostoc, Enterococcus, Lactococcus, and Streptococcus which are fed by the soluble carbohydrates found in the forage (Pahlow et al., 2003). These bacteria produce lactic acid, causing the $\mathrm{pH}$ of the silage to decrease to around 4.0; a standard $\mathrm{pH}$ value for adequate fermentation (Figure 5). LAB can be further subdivided into two types of sugar fermentation: homofermentation and heterofermentation. Concurrently occurring, homofermenters primarily produce lactic acid while heterofermenters produce lactic acid, ethanol, acetic acid, and carbon dioxide.

\subsubsection{Phase 3 -Stable Phase}

If oxygen is kept from the silage, the intensity of fermentation will begin to decrease as readily available fermentable sugars are depleted, leading the silage into the stable phase. 
This phase can last anywhere from a few months to a year, depending on the quality of the silage. Most producers will only keep silage ensiled until the following harvesting season. During this phase, there is a continuous supply of water-soluble carbohydrates due to acid hydrolysis of stored carbohydrates by acid tolerant enzymes. In the previous phase, LAB produced products that decreased the $\mathrm{pH}$ of the silage, but when these products build up and the $\mathrm{pH}$ reaches low values (Figure 5), it causes negative feedback inhibition of LAB. With the low $\mathrm{pH}$, acid tolerant yeast species, bacilli and clostridia remain dormant. Accumulation of these dormant microorganisms can lead to potential issues during the feed-out phase such as mold formation and heat build-up (Pahlow et al., 2003).

\subsubsection{Phase 4 - Feed-out Phase}

When the silo is opened, and the silage is exposed to sufficient amounts of oxygen, the feed-out phase begins. With enough atmospheric oxygen exposure, undesirable microorganisms such as yeast, fungi, mold, and aerobic spoilage bacteria consume digestible DM and release mycotoxins causing the nutritional value of the silage to degrade (Nadeau and Barnhart 2008; McGarvey et al., 2013). Researchers have identified yeast as the primary trigger of aerobic spoilage of silages (McDonald et al., 1991; Wang et al., 2016). This was verified by the findings of Wang et al., (2016) who identified lactic-acid utilizing yeasts as the first to propagate in high levels within ensiled total mixed rations during the feed-out phase.

Aerobic stability is an excellent measure of the quality and stability of the silage once exposed to ambient oxygen. Testing the aerobic stability of silage includes leaving a small amount of silage within an open container, placing an electronic thermal recorder within 
the silage and recording both the ambient and the silage temperatures at set intervals for a period of time. Aerobic stability is represented as the length of time elapsed before a $2^{\circ} \mathrm{C}$ difference is detected between the ambient and silage temperatures. This increase in temperature can be explained by the microbial oxidation of water-soluble carbohydrates such as the transformation of lactic and acetic acid into carbon dioxide and water. After this temperature change, the silage is said to be deteriorated and no longer suitable for animal consumption. (Wang et al., 2016) 


\section{OBJECTIVES}

The objectives of this study were (1) to determine the effects of chemical (urea and calcium oxide) and bacteria (lactic acid bacteria) inoculants in combination with ensiling, on the nutritional value and ensiling compatibility of olive pomace and (2) to identify the most biologically favorable treatment and ensiling day of olive pomace for feeding to cattle. 


\section{MATERIALS AND METHODS}

\subsection{Experimental Design}

\subsubsection{Mini-Silos}

Eighty 18.9 L plastic buckets (Home Depot, Atlanta, GA) were used for this experiment as the mini-silos. A small hole was drilled through the center of the lid to form the ventilation system. A large pipet tip with the top 6-7 mm cut off was placed through the hole in the bucket lid so that the tip faced out. Painter's all-purpose acrylic latex caulk (DAP, Baltimore, MD) was used to seal the area surrounding the pipet. Approximately 203 $\mathrm{mm}$ long clear plastic hose was tightly inserted on the pipet. The end of the hose was bent and secured with a medium binder clip. These hand-made ventilation systems allowed for the release of gas during the initial few days of ensiling in order to prevent a rupture in the mini-silos.

\subsubsection{Treatments}

Freshly centrifuged OP from Olivas de Oro Olive Company (Creston, CA) was received in large bins by the Animal Science Department, California Polytechnic State University (San Luis Obispo, CA) in November 2016. OP samples from the top, middle, and bottom of each bin were collected for the determination of initial \%DM prior to treatment application. Subsamples were weighed out onto pre-weighed labeled aluminum trays and placed in a forced-air drying oven (Bench Series oven, Quincy Labs Inc., Chicago, IL) at $55^{\circ} \mathrm{C}$ for $72 \mathrm{~h}$. Each tin with sample was removed from the oven, covered with foil and allowed to cool for at least $30 \mathrm{~min}$. Once cooled, the foil was removed and each tin with sample was weighed. Dry matter at $55^{\circ} \mathrm{C}$ was calculated as the final 
sample weight divided by the original fresh sample weight and multiplied by 100 for a percent value. This value allowed for the proper calculation of amount of treatment added.

Olive pomace (OP) was evenly mixed within each bin to ensure consistent and homogeneous product. Four pre-weighed 18.9 L buckets (Home Depot, Atlanta, GA) were filled with OP from all bins and reweighed. The OP was dumped onto clean $3.05 \times 6.10 \mathrm{~m}$ plastic sheets and evenly spread. The sum of the four recorded OP weights was multiplied by the DM concentration calculated earlier to get the weight of the OP on a dry matter basis (DM basis).

Treatments included 4 inoculations and 5 ensiling days in a factorial arrangement replicated 5 times. Fresh olive pomace was subjected to one of four inoculations: (1) no additives (control; CONT); (2) urea (UREA; Agrium U.S. Inc, Loveland, CO) applied at 5\% of DM; (3) SiloSolve MC (SS; Chr. Hansen A/S, Hørsholm, Denmark) dissolved in distilled water and applied at a rate of $2.2 \mathrm{mg} / \mathrm{kg}$ of olive pomace; or (4) SiloSolve MC applied at the same rate as treatment 3 with calcium oxide (CAO; Flinn Scientific, Batavia, IL) applied at 5\% of DM. SiloSolve MC inoculant application followed the manufacturer's suggested dose of 60,000 cfu/ $\mathrm{g}$ of fresh olive pomace for Enterococcus faecium M74, 45,000 cfu/ $\mathrm{g}$ of fresh olive pomace for Lactococcus lactis SR3.54, and 45,000 cfu/g of fresh olive pomace for Lactobacillus plantarum CH6072. SiloSolve MC was evenly sprayed and powdered inoculants (urea and calcium oxide) were evenly spread on fresh olive pomace under constant mixing. After completely mixing in inoculant, two $300 \mathrm{~g}$ subsamples were removed from each OP pile representing the treated sample at $0 \mathrm{~d}$ of ensiling. These samples were subjected to all procedures as discussed in the methodology section. Twenty $\mathrm{kg}$ (fresh basis) of the inoculated olive pomace were packed into 18.9-L plastic buckets (Home Depot, Atlanta, GA) with hand-made gas pressure release valves. The 
contents were weighed on a large digital bench scale (SD200 AM, 440 lb capacity, Ohaus, Parsippany, NJ) and each bucket was randomly assigned to one of the four ensiling periods:

2, 10, 60 and $120 \mathrm{~d}$. This process was repeated four additional times for a total of 80 buckets: five replicates for every treatment and ensiling period combination. Buckets were kept together in the same room with minimum exposure to the outside environment.

\subsubsection{Sample Collection}

For each ensiling period, the assigned buckets were opened and immediately weighed on a large digital bench scale (SD200 AM, 440 lb capacity, Ohaus, Parsippany, NJ). If spoilage was present, the thickness of the layer was measured followed by removal of the entire layer. The bucket was then placed back on the scale to record the weight without spoilage. Random samples from the top, middle and bottom of the mini-silo were removed and placed onto a clean table. The samples were mixed thoroughly followed by the quartering procedure which entails dividing the sample into four equal parts and using the two opposite quarters as representative samples (Figure 6). This was repeated until the appropriate amount of sample needed remained (Servi-Tech Laboratories). Approximately $500 \mathrm{~g}$ of the representative sample was weighed into pre-weighed, numbered aluminum tins, in duplicate. An additional $10 \mathrm{~g}$ representative subsample of OP was collected from each sample pile and placed in a labeled 1,242 mL Whirl-Pak Standard bag (Nasco, Fort Arkinson, WI) and used for water extract analysis discussed in the ensiling compatibility section. 


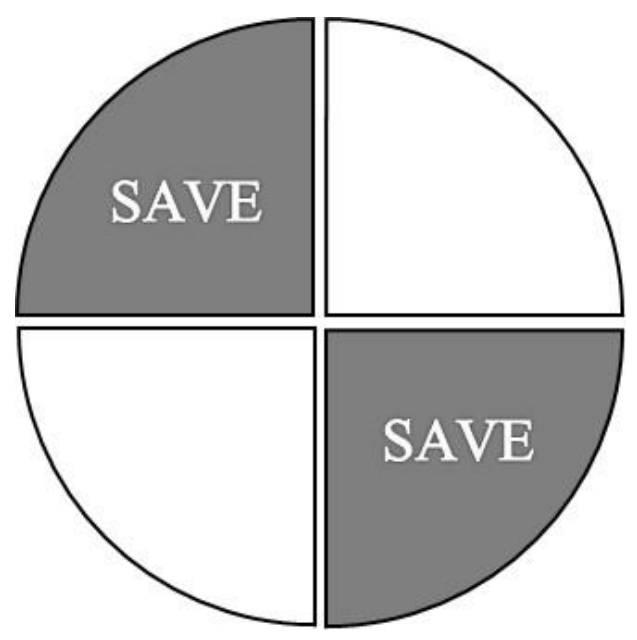

Figure 6: Quartering procedure for representative feed sampling. Adapted from Servi-Tech Laboratories.

\subsection{Chemical Composition}

\subsubsection{Dry Matter, Organic Matter and Ash}

OP samples were analyzed for dry matter (DM), organic matter (OM), and ash in duplicate (AOAC, 1990). Aluminum tins with fresh OP silage were placed in a forced-air drying oven (Bench Series oven, Quincy Labs Inc., Chicago, IL) pre-heated to $55^{\circ} \mathrm{C}$ for $\mathrm{Z}$ h. Each tin with sample was then removed from the oven, covered with foil and allowed to cool for at least $30 \mathrm{~min}$ but no more than $1 \mathrm{~h}$. Once cooled, the foil was removed and each tin with sample was weighed. Dry matter at $55^{\circ} \mathrm{C}$ was calculated as the final dry sample weight divided by the original fresh sample weight and multiplied by 100 for a percent value. Dried OP samples were individually ground through a $5.0 \mathrm{~mm}$ screen using a standard model Number 3 Wiley mill (Thomas Scientific ${ }^{\circledR}$, Swedesboro, NJ) into 1,242 mL Whirl-Pack bags (Nasco, Fort Arkinson, WI). Approximately $150 \mathrm{~g}$ of each OP sample was further ground through a $1.0 \mathrm{~mm}$ screen using a standard model Number 3 Wiley Mill (Thomas Scientific ${ }^{\circ}$, Swedesboro, NJ) into $710 \mathrm{~mL}$ Whirl-Pak bags (Nasco, Fort 
Arkinson, WI). All chemical composition analyses were performed on $55^{\circ} \mathrm{C}$ DM samples, unless otherwise noted, and later converted to reflect $100^{\circ} \mathrm{C}$ DM basis.

Clean and dry $30 \mathrm{~mL}$ porcelain crucibles (Fisher Brand, Pittsburg, PA) were placed into a $105^{\circ} \mathrm{C}$ forced-air drying oven (Bench Series oven, Quincy Labs Inc., Chicago, I) for $2 \mathrm{~h}$ prior to use. After $2 \mathrm{~h}$, the crucibles were removed and placed into a desiccator for $1 \mathrm{~h}$ to cool. Once cooled, the crucible was weighed, tared, and 0.9899 to $1.1199 \mathrm{~g}$ of $1.0 \mathrm{~mm}$ ground OP sample was weighed into the crucible. Samples were weighed and processed according to treatment combination (i.e., all OP samples treated with UREA and ensiling for $60 \mathrm{~d}$ were analyzed together). All samples were analyzed in duplicates. The crucible with sample was then placed back into the forced-air drying over for $24 \mathrm{~h}$, after which the crucible was removed and placed into a desiccator for $1 \mathrm{~h}$ to cool. After cooling, each crucible with $\mathrm{OP}$ sample was individually weighed. Dry matter at $105^{\circ} \mathrm{C}$ was calculated as the final dry sample weight divided by the original sample weight and multiplied by 100 for a percent value.

The crucibles with sample were then placed evenly spaced out into a muffle furnace (Barkmeyer M-525 Series II furnace, Neytech, Bloomfield, CT) for approximately $10 \mathrm{~h}$. The muffle furnace was allowed to heat up to $600^{\circ} \mathrm{C}$, maintain this temperature for $2 \mathrm{~h}$ and then cool to $200^{\circ} \mathrm{C}$ over a few hours. The crucibles were carefully removed from the muffle furnace and placed into a desiccator for $1 \mathrm{~h}$ to cool. Once the crucibles were weighed again, percent ash was calculated. Subtracting the percentage of ash from DM (\%) calculated the OM (DM basis) for each sample. 


\subsubsection{Neutral Detergent Fiber, Acid Detergent Fiber and Acid Detergent}

\section{Lignin}

Dried OP samples ground to $1.0 \mathrm{~mm}$ were used for the determination of neutral detergent fiber (NDF), sequential acid detergent fiber (ADF), and sequential acid detergent lignin (ADL) concentrations. All samples were analyzed in duplicate. A Mettler Toledo XS105 DualRange analytical balance (Mettler Toledo, Columbus, OH) was used to weigh out 0.4500 to $0.5200 \mathrm{~g}$ of OP sample into labeled, pre-weighed filter bags (F57, Ankom Technology, Macedon, NY) of 25 microns porosity. Once filled, the filter bags were heatsealed using an AIE-200 Impulse Hand Sealer (American International Electric Inc., City of Industry, CA) approximately $2 \mathrm{~mm}$ and $4 \mathrm{~mm}$ from the bag opening and allowed to cool for a few secs before removing. With each process, an additional two blank filter bags (no added sample) were also labeled, weighed, and sealed for calculating dry bag weight corrections.

Once all samples were prepared, the filter bags were placed onto bag suspender trays. All 9 trays were placed onto the bag suspender regardless of the number of filter bags being processed. Each tray held a maximum of 3 filter bags except for the top tray with always held none. The bag suspender was placed into the vessel of an Ankom fiber analyzer (Ankom Fiber Analyzer 200, Ankom Technology, Macedon, NY) and 1,500 mL of neutral detergent solution (Ankom Technology, Macedon, NY) and $4 \mathrm{~mL}$ of $\alpha$-amylase (Ankom Technology, Macedon, NY) was poured onto the filter bags. Sodium sulfite was not added to the process. The vessel was closed, sealed, and allowed to heat and agitate for $75 \mathrm{~min}$.

After $75 \mathrm{~min}$, the heat and agitation were turned off. The vessel was slowly vented, and valve opened to release all the liquid. Once all the liquid was expelled, the valve was 
closed, and $1,500 \mathrm{~mL}$ of hot DI water was added to the vessel along with $4 \mathrm{~mL}$ of $\alpha$ amylase. The vessel was close, sealed and allowed to heat and agitate for $5 \mathrm{~min}$. This rinsing process was repeated a second time with the addition of $\alpha$-amylase and a third time without $\alpha$-amylase. Once the rinsing process was complete, the filter bags were removed from the trays, very gently compressed to remove excess water, and soaked in acetone (Ankom Technology, Macedon, NY). After 5 min of soaking the bags were removed and placed onto a wire tray where they dried under a vented chemical fume hood for $24 \mathrm{~h}$. The wire tray with bags was then placed in a pre-heated forced-air drying oven (Bench Series oven, Quincy Labs Inc., Chicago, IL) set at $55^{\circ} \mathrm{C}$ for $2-4 \mathrm{~h}$. After drying, the bags were placed into beakers inside a desiccator and cooled for $1 \mathrm{~h}$. After cooling, the bags were individually weighed and neutral detergent fiber concentration (\%) was calculated as (Ankom, 2017b):

$$
\begin{aligned}
& \% \mathrm{NDF}(\mathrm{DM} \text { basis })=\left(\frac{100 \times[\mathrm{W} 3-(\mathrm{W} 1 \times C 1)]}{W 2}\right) \times \% D M \\
& \text { Where, } \mathrm{W} 1=\text { bag tare weight }(\mathrm{g}) \\
& \mathrm{W} 2=\text { initial sample weight }(\mathrm{g}) \\
& \mathrm{W} 3=\text { dried weight of bag with sample }(\mathrm{g}), \text { after each analysis } \\
& \mathrm{C} 1=\text { blank bag correction, average of }\left(\frac{\text { final dry bag weight }(\mathrm{g})}{\text { initial bag weight }(g)}\right) \\
& \% \mathrm{DM}=100^{\circ} \mathrm{C} \text { dry matter percentage for each sample }
\end{aligned}
$$

After completing NDF analysis of the filter bags, they were returned to the trays and placed in the bag suspender within the analyzer vessel. The vessel was filled with 1,500 $\mathrm{mL}$ of acid detergent lignin (Ankom Technology, Macedon, NY), closed, sealed, and allowed to heat and agitate for $60 \mathrm{~min}$. After $1 \mathrm{~h}$, heat and agitation were turned off and the 
vessel was vented before removing all liquid as previously described. With the valve closed, 1,500 mL of hot DI water was added and the machine was allowed to heat and agitate for $5 \mathrm{~min}$. Two additional rinses were performed following the same steps. After the third rinse, the $\mathrm{pH}$ of the bags was checked by gently placing a litmus paper against a few of the bags. If the $\mathrm{pH}$ was still acidic, the bags were returned to the vessel and an additional rinsing was performed. This process was repeated until the litmus paper read a neutral $\mathrm{pH}$ meaning no sulfuric acid remained. After the final rinse, the filter bags were soaked in acetone (Ankom Technology, Macedon, NY) for $5 \mathrm{~min}$. The same fume hood and oven drying procedures were followed as previously discussed. After drying, the bags were placed into beakers inside a desiccator and cooled for $1 \mathrm{~h}$. After cooling, the bags were individually weighed and sequential acid detergent fiber concentration (\%) was calculated using the same calculation as \%NDF (Ankom, 2017a).

Once the ADF analysis was complete, the filter bags were placed into a $3 \mathrm{~L}$ beaker under the fume hood and completely covered with $300 \mathrm{~mL}$ of $72 \% \mathrm{H}_{2} \mathrm{SO}_{4}$ (Ankom Technology, Macedon, NY). A $2 \mathrm{~L}$ beaker was placed inside the $3 \mathrm{~L}$ beaker to keep the bags submerged in the acid. The bags were agitated at start by gently lifting and pushing down the $2 \mathrm{~L}$ beaker approximately 30 times. This agitation process was done in 30 -min intervals. After $3 \mathrm{~h}$, the $\mathrm{H}_{2} \mathrm{SO}_{4}$ was removed and the filter bags were very carefully rinsed under cold DI water until all acid was removed. Litmus paper was pressed against the bags to determine the $\mathrm{pH}$. Once at a neutral $\mathrm{pH}$, the filter bags were soaked in acetone (Ankom Technology, Macedon, NY) for 3 min to remove excess water. The filter bags were placed on a wire tray and dried under a vented chemical fume hood for $24 \mathrm{~h}$. The same drying and cooling procedures were followed as previously discussed. After cooling, the bags were 
individually weighed and sequential acid detergent lignin concentration (\%) was calculated using the same calculation as \%NDF (Ankom, 2016).

\subsubsection{Nitrogen and Protein}

OP samples ground to $1.0 \mathrm{~mm}$ were used for the automated instrumental analysis of total nitrogen followed by calculated crude protein concentration. A Mettler Toledo XS105 DualRange analytical balance (Mettler Toledo, Columbus, $\mathrm{OH}$ ) was used to weigh out 250 to $350 \mathrm{mg}$ of OP sample into pre-weighed VarioMax steel crucibles. The weight was electronically recorded in the VarioMax CN Analyzer program (Elementar, Langenselbold, Germany) and the crucibles were placed in the designated labeled crucible holder. Two blanks and three standards (Tomato Leaves, NIST® SRM® 1573a, Sigma- Aldrich, St. Louis, MO) were used at the beginning of every run to calibrate the instrument. An additional standard (Tomato Leaves, NIST® SRM® 1573a, Sigma-Aldrich, St. Louis, MO) was weighed out every 10 samples. Every $4^{\text {th }}$ OP sample was duplicated. The "plant" method was selected before running the program on the samples.

After all the samples were run, each standard sample was verified against its known nitrogen concentration to identify any calibration issues. If a standard was inaccurate, all following samples were presumed to be inaccurately measured and were later re-run. The program output provided the nitrogen concentration of every sample and crude protein concentration was determined by multiplying the percent nitrogen by 6.25 :

$\% \mathrm{CP}(\mathrm{DM}$ basis $)=(\% N \times 6.25) \times \% D M$ 


\subsubsection{Fat Extraction}

Dried OP samples ground to $1.0 \mathrm{~mm}$ were sent to Rock River Laboratories (Visalia, CA). Acid hydrolysis and fat extraction were performed consecutively for the determination of total fat in the sample following the ANKOM Acid Hydrolysis procedure for dry/granular samples (Ankom, 2017). An analytical balance (TB Balance Hardware, Ankom Technologies, Macedon, NY) was used to weigh out $0.5 \mathrm{~g}$ of Diatomaceous Earth (DE) (Ankom Technologies, Macedon, NY) and $1.0 \mathrm{~g}$ of sample into labeled, pre-weighed filter bags (XT4, Ankom Technology, Macedon, NY). Once filled and weighed, the filter bags were heat-sealed using an impulse hand sealer (HS, Ankom Technology, Macedon, $\mathrm{NY}$ ) within $4 \mathrm{~mm}$ of the bag's opening and allowed to cool for a few secs before removing. The edges of the sealed filter bag were squeezed, and the contents shaken within to completely cover the sample with the DE. This process was repeated for all samples with two blanks prepared every 15 samples. Each set of blanks were filled with $0.5-0.75 \mathrm{~g}$ of DE, heat sealed, and inserted into the Multi-bag Holder (H33, Ankom Technologies, Macedon, NY) with 15 sample-filled filter bags. The Multi-bag Holder was placed into the hydrolysis vessel of an Ankom ${ }^{\mathrm{HCl}}$ Hydrolysis System (Ankom Technologies, Macedon, NY) followed by $500 \mathrm{~mL}$ of 3N HCl (Ankom Technologies, Macedon, NY). A rolled paper towel was placed on the vessel lid just above the hinge to prevent liquid from getting on the hinge. The lid was closed, and the settings were programed to $60 \mathrm{~min}$ of hydrolysis at $90^{\circ} \mathrm{C}$ followed by $20 \mathrm{~min}$ of rinsing.

When the automated process was complete, the Multi-bag Holder was removed from the vessel and individual filter bags were placed on four layers of paper towels. The wet filter bags were covered with two additional layers of paper towels and the Ankom Blotter 
(H35, Ankom Technologies, Macedon, NY) was used twice to apply uniform pressure to the bags for two min for the removal of excess water. Filter bags were then placed in an Ankom ${ }^{\mathrm{RD}}$ Dryer (RD, Ankom Technologies, Macedon, NY) set at $105^{\circ} \mathrm{C}$ for three h. After drying, the samples were cooled in a desiccant pouch containing $\mathrm{pH}$ paper. If the $\mathrm{pH}$ paper indicated the presence of acid, the bags were placed back in the dryer for further drying. Once the $\mathrm{pH}$ paper was neutral, the weight of the filter bags was recorded.

Fat extraction was performed following acid hydrolysis of the samples. Fifteen sample filter bags from the acid hydrolysis procedure were placed into the bag holder (101.2, Ankom Technologies, Macedon, NY). The appropriate solvent was selected on the Ankom ${ }^{\mathrm{XT15}}$ Extractor (Ankom Technologies, Macedon, NY) display. Using the extraction vessel handle, the extraction vessel was pulled out far enough to add the bag holder into the PTFE insert. The extraction vessel was moved back to its original position and locked in place. The program was set to 60 min of extraction at $90^{\circ} \mathrm{C}$ and initiated. After the automated process was complete and the pressure gauge read zero, the extraction vessel was removed, and the bag holder taken out from the PTFE insert. All sample bags were removed from the bag holder and placed in an Ankom ${ }^{\mathrm{RD}}$ Dryer (RD, Ankom Technologies, Macedon, NY) set at $110^{\circ} \mathrm{C}$ for $15-30 \mathrm{~min}$. After drying, the filter bags were allowed to cool to room temperature in a desiccant pouch before weighing. Total fat was calculated as (Ankom, 2017c):

$$
\% \text { Total Fat }=\left(\frac{100 \times[W 2-(W 3+(C 1-C 2))]}{W 1}\right)
$$

Where, W1 = initial sample weight $(\mathrm{g})$

$$
\begin{aligned}
& \text { W2 = weight of dried sample, filter bag, and DE after hydrolysis (g) } \\
& \text { W3 = weight of dry extracted sample, filter bag and DE (g) }
\end{aligned}
$$




$$
\begin{aligned}
& \mathrm{C} 1 \text { = weight of dry blank filter bag after hydrolysis }(\mathrm{g}) \\
& \mathrm{C} 2 \text { = weight of dry blank filter bags after extraction }(\mathrm{g})
\end{aligned}
$$

\subsection{In Situ Digestibility}

\subsubsection{Dry Matter Digestibility}

Ruminal degradability was measured using a similar nylon bag method as described by Schroeder et al. (2014). OP samples ground to $4 \mathrm{~mm}$ were used to analyze for dry matter digestibility (DMD). A Mettler Toledo XS105 DualRange analytical balance (Mettler Toledo, Columbus, OH) was used to weigh out 9.500 to $10.200 \mathrm{~g}$ of sample. Samples were weighed into labeled, pre-weighed $10 \mathrm{~cm}$ x $20 \mathrm{~cm}$ nylon bags with $50 \mu \mathrm{m}$ pore size (R1020 Forage Bag, Ankom Technologies, Macedon, NY) and tied. Six bags were prepared from each sample totaling 600 nylon bags. The six bags for each sample were randomly assigned to one of six combinations of time period $(12,24$, or $48 \mathrm{~h}$ ) and cow (A or B) (i.e., cow A/12 h). All bags were grouped by their assigned time period and cow combination (100 total nylon bags per combination) and placed into large lingerie bags with metal washers for weighing them down. The lingerie bags were closed and the end securely tied with a long string having a labeled metal washer secured at the end. Two additional bags were prepared to determine the "washout" $(0 \mathrm{~h})$ value of the olive pomace from the in situ bags at every incubation hour. These bags were not placed in the rumen but were subjected to the same rinsing and drying procedures as the incubated bags. The "washout" value for DM and NDF was analyzed and subtracted from the final in situ disappearances (Schroeder et al., 2014). 
Two non-lactating Holstein dairy cows fed the same diet were used for the determination of in situ DM digestibility. With the cows secured in the head locks, the cannula area was cleaned of debris and the cannula lid removed. Using a gloved hand, feed was removed as a tunnel was formed towards the bottom of the rumen. Once the forage mat layer was passed and the bottom liquid layer was felt, one of the lingerie bags was pushed down into the liquid layer of the rumen at a time until all three lingerie bags were in each of the two cows' rumens with the labeled washers hanging out. The cannula lid was securely placed back on and the cows were released from their head locks.

At 12,24 , and $48 \mathrm{~h}$, the designated lingerie bag from each cow was carefully removed and placed in a bucket of cold water to halt microbial activity. Each lingerie bag was untied, and the nylon bags were placed in a 5-gallon bucket filled half ways with cold water. The washout bags for each period were also added to the bucket. These washout bags help distinguish the DM disappearance from each subset of samples during the washing process as oppose to the DM disappearance in situ. The following washing method was implemented:

1. Simultaneously, push all the bags down and twist them to the right within the water 10 times.

2. Simultaneously, push the bags down and twist them to the left within the water 10 times.

3. Push all the bags straight down into the water 10 times.

4. Remove one bag at a time from the water and very gently compress it between your palms to remove water.

5. Place the bag into the next bucket of water. 
6. Repeat step 5 until all bags are transferred to new bucket.

This washing method was repeated nine times. After the tenth wash, the nylon bags were laid out on aluminum foil sheets inside a forced-air drying oven (Bench Series oven, Quincy Labs Inc., Chicago, IL) pre-heated to $55^{\circ} \mathrm{C}$ for $72 \mathrm{~h}$. After $72 \mathrm{~h}$, the nylon bags were removed and then placed in a desiccator to cool for $1 \mathrm{~h}$. The string was carefully cut from the nylon bag before weighing each bag individually. In situ DM digestibility (DMD) was calculated.

$$
\begin{aligned}
\% \mathrm{DMD}(\mathrm{DM} \text { Basis })= & \left(1-\left(\frac{\text { weight of OP post incubation }}{\text { weight of OP pre incubation }}\right) \times 100\right)- \\
& \left(1-\left(\frac{\text { weight of OP washout post incubation }}{\text { weight of OP washout pre incubation }}\right) \times 100\right)
\end{aligned}
$$

\subsubsection{NDF digestibility}

After calculating DMD, each sample was individually ground to $1 \mathrm{~mm}$ using a tabletop, stainless steel, grinding mill (3383-L60, Thomas Scientific $®$, Swedesboro, NJ), into $710 \mathrm{~mL}$ Whirl-Pak bags (Nasco, Fort Arkinson, WI). The samples were then used to determine NDF (Ankom, 2017b). This NDF protocol directly followed the previously discussed NDF protocol with the exception of a duplicate for each sample. One filter bag was prepared for each in situ sample and the in situ replicates were treated as replicates for the NDF procedure. Neutral detergent fiber digestibility was determined by using the weight of olive pomace NDF in the same equation as DMD\%, above. 


\subsection{Ensiling Compatibility}

\subsubsection{Dry Matter Recovery}

Upon opening, each bucket was weighed, the spoilage layer removed, and then reweighed. After calculating the dry matter (DM, \%) concentration of the sample, dry matter recovery (DMR) percentage was determined following Arriola et al. (2011) procedure.

\subsubsection{Acids and $\mathbf{p H}$}

Sterile 0.07M Potassium Phosphate buffer was made prior to sampling by mixing 5.87 g of $\mathrm{KH}_{2} \mathrm{PO}_{4}$ (Potassium Phosphate monobasic, Santa Cruz Biotechnologies, Dallas, TX) and $4.65 \mathrm{~g}$ of $\mathrm{K}_{2} \mathrm{HPO}_{4}$ (Potassium Phosphate dibasic, Santa Cruz Biotechnologies, Dallas, TX) with 1,000 mL of DI water, followed by autoclaving.

Each sterile 1,242 mL Whirl-Pak Standard bag (Nasco, Fort Arkinson, WI) containing $10 \mathrm{~g}$ of representative OP silage sample received $90 \mathrm{~mL}$ of $0.07 \mathrm{M}$ Potassium Phosphate buffer. The Whirl-Pak sample bag was placed into a thicker plastic bag to prevent sample loss during the homogenizing process. Each set of bags was coupled to a Stomacher® 400 circulator (Seward, Worthing, West Sussex, UK) at $260 \mathrm{rpm}$ for $1 \mathrm{~min}$. Sample extract was filtered through sterile cheesecloth into a sterile $400 \mathrm{~mL}$ beaker and the remaining contents were discarded. A $50 \mathrm{~mL}$ centrifuge tube (VWR, Radnor, PA) was filled with filtrate, labeled with sample ID and dilution, and set aside. A separate $13 \mathrm{~mL}$ of filtrate was added to a $30 \mathrm{~mL}$ Leakproof HDPE wide-mouth bottle (Fisher Scientific, Hampton, NH) and the $\mathrm{pH}$ recorded. Using 50\% Sulfuric acid, the $\mathrm{pH}$ of the filtrate was dropped below 2.0. The bottle was sealed and labeled. Both the $50 \mathrm{~mL}$ nonacidified and $\sim 13 \mathrm{~mL}$ acidified samples 
were frozen. After all samples were collected, the frozen samples were shipped in a cooler to the School of Food and Agriculture, University of Maine (Orono, ME) for further analysis. Thawed samples were centrifuged at $8,000 \times \mathrm{g}$ for $20 \mathrm{~min}$ at $4^{\circ} \mathrm{C}$ and the supernatant was analyzed for lactic, acetic, butyric, and propionic acids, and ethanol concentrations (Siegfried et al., 1984) using a HPLC system fitted with a Hi-Plex H ion exchange column and a 1200 series G1362A Infinity refractive index detector (all sourced from Agilent, Santa Clara, CA). Ammonia-N concentration was measured using an adaptation of the Noel and Hambleton (1976) procedure that involved colorimetric N quantification with a Seal AQ2 discrete auto analyzer (Seal Analytical Inc). Water-soluble carbohydrate (WSC) concentration was measured from the non-acidified samples using the protocol by DuBois et al (1956) using sucrose as the standard as described by Hall (2000). Lactic acid to acetic acid ratio (LA:AA) was then calculated as:

$$
\mathrm{LA}: \mathrm{AA}=\frac{\text { acetic acid }}{\text { lactic acid }}
$$

Homolactic index was then calculated as:

$$
\text { Homolactic index }=\frac{\text { lactic acid }}{(\text { acetic acid }+ \text { ethanol })}
$$

\subsubsection{Microbial Counts}

OP samples were analyzed for lactic acid bacteria (LAB), yeast and mold colony counts in duplicate. Serial dilutions of the original filtrate were made in labeled $50 \mathrm{mLcentrifuge}$ tubes (VWR, Radnor, PA) using additional 0.07M Potassium Phosphate buffer. Tubes containing the serial dilutions were inverted prior to every plating protocol to allow for a homogenized sample collection. For every sample, $0.1 \mathrm{~mL}$ of each serial dilution was even 
spread using a sterile glass rod onto a labeled G179 Lactobacillus MRS agar with Cycloheximide, 15 x $60 \mathrm{~mm}$ plate (Hardy Diagnostics, Santa Maria, CA) in duplicate. The plates were allowed to set for a couple minutes before being placed upside down in an incubator set at $35^{\circ} \mathrm{C}$ for $2-3 \mathrm{~d}$. After incubation, the plates were removed one at a time and placed under a lit colony counter. The counting limit for lactobacillus plates were set at 30 to 300 colonies (Ni et al., 2015). All LAB colonies were counted and recorded with the corresponding dilution factor. LAB colonies appear large and are of cream color as depicted in Figure 7 below.

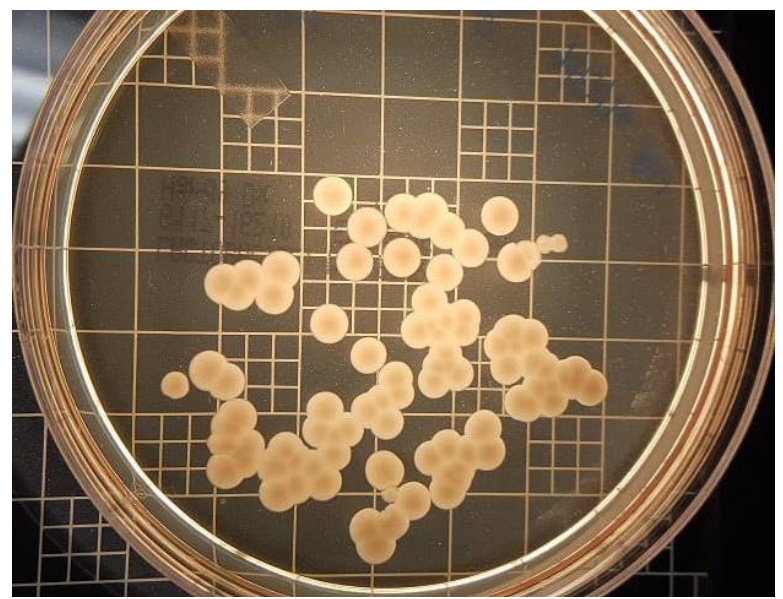

Figure 7: Lactobacillus colonies, identified as large in size and of cream color.

All sample dilutions were used for identifying yeast and mold colony counts on $3 \mathrm{M}^{\mathrm{TM}}$ Petrifilm $^{\mathrm{TM}}\left(3 \mathrm{M}\right.$, St. Paul, MN) in duplicate. A Petrifilm ${ }^{\mathrm{TM}}$ plate was placed on a leveled surface and the top film was lifted. A $1.0 \mathrm{~mL}$ sample of dilution was pipetted perpendicular to the Petrifilm ${ }^{\mathrm{TM}}$ plate onto the center of the bottom film. The top film was let go and allowed to drop onto the sample. The Petrifilm ${ }^{\mathrm{TM}}$ yeast and mold spreader (3M, St. Paul, $\mathrm{MN}$ ) was placed on the center of the plate and a gentle downward pressure was applied to 
the center. This allowed for the even distribution of the sample on the Petrifilm ${ }^{\mathrm{TM}}$. The spreader was removed and the Petrifilm ${ }^{\mathrm{TM}}$ gel was allowed to set for a few minutes before being placed in an incubator set at $25^{\circ} \mathrm{C}$ for $3-5 \mathrm{~d}$. After incubation, the Petrifilm ${ }^{\mathrm{TM}}$ was placed under a lit colony counter where yeast and mold colony counts were counted and recorded separately with the corresponding dilution factor. The counting limit for the $3 \mathrm{M}$ Petrifilm ${ }^{\mathrm{TM}}$ was set at a minimum of 10 for both yeast and mold colonies (Tournas et al., 2001) and a maximum of 300 and 100, respectively. Yeast colonies are small, appear raised and have defined edges. Each colony is uniform in color, but colors can vary from pink/tan to blue/green. Mold colonies are larger than yeast colonies, appear flat, and contain diffused edges. They can be brown, beige, orange or blue/green in color and usually contain a darker colored center (3M, 2014; 3M, 2004).

Using the appropriate colony counts and associated dilution factors, the LAB, yeast, and mold counts were corrected to the proper dilution factor and expressed as log colony forming unit (cfu) per gram of fresh matter (FM), calculated as:

Log cfu / g FM $=\log _{10}$ corrected counts

Corrected counts $=$ raw counts $\times$ dilution factor

\subsubsection{Aerobic Stability}

After subsampling olive pomace from the mini silo, most of the olive pomace was removed, only leaving $2 \mathrm{~kg}$ of material inside. The Hoboware Pro software (ONSET, Bourne, MA) was used to launch each HOBO Pendant temperature 64K data logger (ONSET, Bourne, MA); labeling the logger with the corresponding sample ID number, setting the temperature reading to Celsius $\left({ }^{\circ} \mathrm{C}\right)$, a delayed start time matching all loggers 
for that ensiling period, and a recording interval of every $30 \mathrm{~min}$. Each data logger was carefully placed in the center of the silage sample within each mini silo and covered with material; not in contact with the bottom of the bucket or the ambient temperature. Silage was covered with two layers of sterile cheesecloth to prevent drying of the product. All mini silos were placed back in the room and left opened. Four additional data loggers were placed randomly around the room to measure ambient temperature. The data loggers recorded the ambient and silage temperatures every 30 min for $14 \mathrm{~d}$. After $14 \mathrm{~d}$, the loggers were removed from the material, cleaned with DI water, and connected to the Hoboware Pro software (ONSET, Bourne, MA) to read out and save the recording. The differences between the silage and ambient temperatures at a given time were calculated. Ambient temperature was defined as the period of time elapsed before a $2^{\circ} \mathrm{C}$ difference is observed between the silage and the ambient temperatures. 


\section{STATISTICAL ANALYSIS}

All microbial data were transformed to $\log 10$ for presentation and statistical analysis. Data were analyzed as a completely randomized design. This included 4 treatments, 5 replications, and 5 ensiling days. The model included the fixed effects of treatment, ensiling days, and their interaction. Proc Mixed in SAS v9.4 (SAS Institute Inc., 2003) was used to analyze the data. Least square means were calculated and separated with PDIFF function in SAS. For in situ data, repeated measures in Proc Mixed was used to test incubation period, ensiling day, treatment, and all subsequent interactions on DMD and NDFD in SAS. The subject was cow nested as a random effect within time. The covariance structure, compound symmetry, was chosen based on the lowest Bayesian information criterion. If a significant interaction was observed, the SLICE option in SAS was used to separate LSmeans. Differences are reported significant at $P \leq 0.05$. Trends were $0.05<P<0.10$. 


\section{RESULTS AND DISCUSSION}

\subsection{Chemical Composition}

The chemical composition parameters of the olive pomace samples are reported in Tables 3 - 11. Initial DM concentrations remained similar with the addition of SS yet increased with UREA and CAO (Table 3). The higher DM concentration can be attributed to the high dry weight of the chemicals within those treatments which decreased the moisture content of the product, as in previous findings using similar chemicals (Owaimer et al., 2004; Felix et al., 2012; Jacovaci et al., 2017). We found DM concentration to decrease with ensiling for all treatments; CAO containing the most DM at $120 \mathrm{~d}(40.8 \pm$ $0.177 \%, \mathrm{P}<0.05)$. Ash concentration increased with ensiling for all treatments with $\mathrm{CAO}$ having higher levels than CONT at $0 \mathrm{~d}(9.09$ vs $4.26 \pm 0.157 \%$ of DM, respectively, Table 5) and throughout ensiling. The chemical reaction between calcium oxide and water leaves behind calcium within the substrate, increasing ash concentration as reported in previous studies with straw and corn stover (Zaman and Owen, 1995 and Shi et al., 2015, respectively). Prolonged ensiling tended to increase the fiber portions for CONT, SS, and UREA (Tables 6, 7 and 8). Although the differences observed were minute and thus potentially not biologically meaningful, the increase in fiber portions could be due to the fermentation of sugars resulting in higher proportions of fiber in the product. On the other hand, CAO had significantly lower NDF, ADF, and ADL concentrations at $0,10,60$, and $120 \mathrm{~d}$ than CONT $(\mathrm{P}<0.05)$, similar to other studies observing alkali-treated silages (Chizzotti et al., 2015; Shi et al., 2015). Sirohi and Rai (1998) suggested that the decrease in NDF of alkali-treated silages can be explained by the partial solubilization of the hemicelluloses and phenolic fractions, allowing for greater exposure of fiber components. 
We found the CP concentration of UREA to remain significantly higher than all other treatments at $0 \mathrm{~d}$ and with ensiling; approximately a 3-fold increase in $\mathrm{CP}$ was observed with the highest concentration at $60 \mathrm{~d}(23.813 \pm 0.429 \%$ of DM, P $<0.001$, Table 9$)$. There was an increase in $\mathrm{CP}$ with prolonged ensiling, similar to the previous findings of Hadjipanayiotou (1994) who found all urea-N applied to be retained on olive cake, most likely due to a lack of urea to ammonia conversion by urease during ensiling. The addition of UREA and SS at $0 \mathrm{~d}$ significantly increased the initial fat content of the product (14.516 and $15.038 \pm 0.548 \%$ of DM, respectively; $\mathrm{P}<0.05$ ) but these effects diminished by $120 \mathrm{~d}$ where fat content was significantly lower than at $0 \mathrm{~d}$ (Table 10, $\mathrm{P}<0.05)$. The increase in fat levels can be explained by a drop in DM due to a loss of proteins and carbohydrates from anaerobic degradation or effluent losses (Bochicchio et al., 2015). As reported in Bochicchio et al. (2015), the silage began to show increased levels of ether extract concurrently with a decrease in ammonia-N; reaching concentrations lower than the $10 \%$ of CP threshold set by Kung and Shaver (2001). We observed ammonia-Nconcentrations below the set threshold, explaining the high fat observed in the samples (Table 10). CAO contained similar fat levels to CONT and both showed no significant change in fat content with prolonged ensiling $(\mathrm{P}>0.05)$.

Initial WSC concentrations were of adequate levels for proper fermentation during ensiling although SS and UREA contained significantly greater concentrations than CONT (19.6 and 17.3 , respectively vs. $14.8 \pm 0.519 \%$ of DM, P $<0.001)$. Higher WSC concentrations are desirable in silages due to their rapid digestibility in the rumen (Kung Jr., 2011). With ensiling, sugars decreased to similar levels among treatments; UREA showing a more rapid decrease from 11.0 at $2 \mathrm{~d}$ to $4.82 \pm 0.519 \%$ of DM at $10 \mathrm{~d}$ (Table 11 , 
$\mathrm{P}<0.001)$. The quicker decrease in WSC for UREA is associated with the release of ammonia and its antimicrobial effects which lead to desirable DM recoveries (Schmidt, 2006). The total fermentation products produced with ensiling (Table 14, 15, 16, and 17), do not account for the large decrease in sugars from initial inoculation. A potential explanation for this could be credited to the presence of yeast under anaerobic conditions that can lead to a decrease in the amount of sugars available for lactic acid fermentation by fermenting sugars to ethanol and $\mathrm{CO}_{2}$ (McDonald et al., 1991).

Table 3: Effects of applying 3 inoculants on mean dry matter (DM, \%) concentration for olive pomace and ensiled for $2,10,60$, and $120 \mathrm{~d}$

\begin{tabular}{lcccc}
\hline & \multicolumn{4}{c}{ Treatment $^{\mathbf{1}}$} \\
\cline { 2 - 5 } Day & CONT & SS & UREA $^{\mathrm{C}}$ & CAO \\
\hline 0 & $36.4^{\mathrm{A}, \mathrm{a}}$ & $36.7^{\mathrm{A}, \mathrm{a}}$ & $38.6^{\mathrm{A}, \mathrm{b}}$ & $41.4^{\mathrm{A}, \mathrm{c}}$ \\
2 & $38.1^{\mathrm{B}, \mathrm{a}}$ & $36.7^{\mathrm{A}, \mathrm{b}}$ & $38.2^{\mathrm{A}, \mathrm{a}}$ & $39.5^{\mathrm{B}, \mathrm{c}}$ \\
10 & $37.6^{\mathrm{B}, \mathrm{a}}$ & $37.1^{\mathrm{A}, \mathrm{a}, \mathrm{b}}$ & $36.7^{\mathrm{B}, \mathrm{b}}$ & $40.2^{\mathrm{C}, \mathrm{c}}$ \\
60 & $36.0^{\mathrm{A}, \mathrm{C}, \mathrm{a}}$ & $35.1^{\mathrm{B}, \mathrm{b}}$ & $36.9^{\mathrm{B}, \mathrm{c}}$ & $39.8^{\mathrm{B}, \mathrm{C}, \mathrm{d}}$ \\
120 & $35.8^{\mathrm{C}, \mathrm{a}}$ & $34.6^{\mathrm{B}, \mathrm{b}}$ & $36.1^{\mathrm{C}, \mathrm{a}}$ & $40.8^{\mathrm{D}, \mathrm{c}}$ \\
& & & & \\
& SEM $^{\mathbf{2}}$ & Trt & Day & Trt x Day \\
\hline & 0.177 & $<0.001$ & $<0.001$ & $<0.001$ \\
\hline
\end{tabular}

A-EMeans with different superscripts in the same column indicate significance, $P<0.05$ ${ }^{\text {a-d }}$ Means with different superscripts in the same row indicate significance, $P<0.05$ ${ }^{1} \mathrm{CONT}=$ no additives; UREA $=$ applied at $5 \%$ of DM; SS $=$ a mixture of Enterococcus faecium M74, Lactococcus lactis SR3.54, and Lactobacillus plantarum CH6072 applied at $1.5 \times 10^{5} \mathrm{cfu} / \mathrm{fresh} \mathrm{g}$; CAO $=$ SS and calcium oxide applied at $5 \%$ of DM.

${ }^{2} \mathrm{SEM}$, standard error of the mean 
Table 4: Effects of applying 3 inoculants on mean organic matter (OM, \%) concentration for olive pomace and ensiled for $2,10,60$, and $120 \mathrm{~d}$

\begin{tabular}{lcccc}
\hline & \multicolumn{4}{c}{ Treatment $^{\mathbf{1}}$} \\
\cline { 2 - 5 } Day & CONT & SS & UREA & CAO \\
\hline 0 & $95.7^{\mathrm{A}, \mathrm{a}, \mathrm{b}}$ & $95.5^{\mathrm{A}, \mathrm{a}}$ & $96.0^{\mathrm{A}, \mathrm{b}}$ & $90.9^{\mathrm{A}, \mathrm{c}}$ \\
2 & $95.5^{\mathrm{A}, \mathrm{a}}$ & $95.0^{\mathrm{B}, \mathrm{b}}$ & $95.2^{\mathrm{B}, \mathrm{a}, \mathrm{b}}$ & $89.7^{\mathrm{B}, \mathrm{c}}$ \\
10 & $94.7^{\mathrm{B}, \mathrm{a}}$ & $94.8^{\mathrm{B}, \mathrm{C}, \mathrm{a}}$ & $94.7^{\mathrm{C}, \mathrm{a}}$ & $87.5^{\mathrm{C}, \mathrm{b}}$ \\
60 & $94.5^{\mathrm{B}, \mathrm{a}}$ & $95.0^{\mathrm{C}, \mathrm{D}, \mathrm{a}}$ & $94.9^{\mathrm{C} . \mathrm{b}}$ & $87.1^{\mathrm{D}, \mathrm{c}}$ \\
120 & $94.7^{\mathrm{B}, \mathrm{a}}$ & $94.4^{\mathrm{D}, \mathrm{b}}$ & $94.8^{\mathrm{C}, \mathrm{a}}$ & $88.6^{\mathrm{E}, \mathrm{c}}$ \\
& & & \\
& SEM $^{\mathbf{2}}$ & Trt & Day & Trt x Day \\
\hline & 0.011 & $<0.001$ & $<0.001$ & $<0.001$ \\
\hline
\end{tabular}

A-EMeans with different superscripts in the same column indicate significance, $P<0.05$

${ }^{\mathrm{a}-\mathrm{d}}$ Means with different superscripts in the same row indicate significance, $P<0.05$

${ }^{1} \mathrm{CONT}=$ no additives; UREA $=$ applied at $5 \%$ of DM; SS $=$ a mixture of Enterococcus faecium M74, Lactococcus lactis SR3.54, and Lactobacillus plantarum CH6072 applied at $1.5 \times 10^{5} \mathrm{cfu} / \mathrm{fresh} \mathrm{g}$; CAO $=\mathrm{SS}$ and calcium oxide applied at $5 \%$ of DM.

${ }^{2} \mathrm{SEM}$, standard error of the mean

Table 5: Effects of applying 3 inoculants on mean ash (\%) concentration for olive pomace and ensiled for $2,10,60$, and $120 \mathrm{~d}$

\begin{tabular}{lcccc}
\hline & \multicolumn{3}{c}{ Treatment $^{1}$} \\
\cline { 2 - 5 } Day & CONT & SS & UREA $^{\mathrm{A}, \mathrm{a}}$ & CAO \\
\hline 0 & $4.26^{\mathrm{A}, \mathrm{a}, \mathrm{b}}$ & $4.51^{\mathrm{a}}$ & $4.05^{\mathrm{A}, \mathrm{b}}$ & $9.09^{\mathrm{A}, \mathrm{c}}$ \\
2 & $4.50^{\mathrm{A}, \mathrm{a}}$ & $5.01^{\mathrm{B}, \mathrm{b}}$ & $4.78^{\mathrm{B}, \mathrm{a}, \mathrm{b}}$ & $10.6^{\mathrm{B}, \mathrm{c}}$ \\
10 & $5.34^{\mathrm{B}, \mathrm{a}}$ & $5.16^{\mathrm{B}, \mathrm{C}, \mathrm{a}}$ & $5.28^{\mathrm{C}, \mathrm{a}}$ & $12.5^{\mathrm{C}, \mathrm{b}}$ \\
60 & $5.46^{\mathrm{B}, \mathrm{a}}$ & $5.48^{\mathrm{C}, \mathrm{a}}$ & $5.11^{\mathrm{C}, \mathrm{b}}$ & $13.0^{\mathrm{D}, \mathrm{c}}$ \\
120 & $5.25^{\mathrm{B}, \mathrm{a}}$ & $5.62^{\mathrm{D}, \mathrm{C}, \mathrm{b}}$ & $5.22^{\mathrm{C}, \mathrm{a}}$ & $11.4^{\mathrm{E}, \mathrm{c}}$ \\
& & & & \\
& $\mathbf{S E M}^{\mathbf{2}}$ & Trt & Day & Trt x Day \\
\hline & 0.157 & $<0.001$ & $<0.001$ & $<0.001$ \\
\hline
\end{tabular}

${ }^{\mathrm{A}-\mathrm{E}}$ Means with different superscripts in the same column indicate significance, $P<0.05$

${ }^{\mathrm{a}-\mathrm{d}}$ Means with different superscripts in the same row indicate significance, $P<0.05$

${ }^{1} \mathrm{CONT}=$ no additives; UREA $=$ applied at $5 \%$ of DM; SS $=$ a mixture of Enterococcus faecium M74, Lactococcus lactis SR3.54, and Lactobacillus plantarum CH6072 applied at $1.5 \times 10^{5} \mathrm{cfu} / \mathrm{fresh}$ g; CAO $=\mathrm{SS}$ and calcium oxide applied at $5 \%$ of DM.

${ }^{2} \mathrm{SEM}$, standard error of the mean 
Table 6: Effects of applying 3 inoculants on mean neutral detergent fiber (NDF, $\%$ ) concentration for olive pomace and ensiled for $2,10,60$, and $120 \mathrm{~d}$

\begin{tabular}{lcccc}
\hline & \multicolumn{4}{c}{ Treatment $^{\mathbf{1}}$} \\
\cline { 2 - 5 } Day & CONT & SS & UREA & CAO \\
\hline 0 & $56.4^{\mathrm{A}, \mathrm{a}}$ & $56.5^{\mathrm{A}, \mathrm{a}}$ & $57.9^{\mathrm{A}, \mathrm{C}, \mathrm{a}}$ & $47.8^{\mathrm{A}, \mathrm{B}, \mathrm{b}}$ \\
2 & $55.7^{\mathrm{A}, \mathrm{a}}$ & $50.7^{\mathrm{B}, \mathrm{b}}$ & $50.7^{\mathrm{B}, \mathrm{b}}$ & $47.3^{\mathrm{A}, \mathrm{B}, \mathrm{b}}$ \\
10 & $54.4^{\mathrm{A}, \mathrm{a}}$ & $55.2^{\mathrm{A}, \mathrm{a}}$ & $58.1^{\mathrm{A}, \mathrm{C}, \mathrm{a}}$ & $48.2^{\mathrm{A}, \mathrm{b}}$ \\
60 & $57.3^{\mathrm{A}, \mathrm{a}}$ & $55.2^{\mathrm{A}, \mathrm{a}}$ & $54.5^{\mathrm{A}, \mathrm{B}, \mathrm{a}}$ & $44.2^{\mathrm{B}, \mathrm{b}}$ \\
120 & $62.9^{\mathrm{B}, \mathrm{a}}$ & $57.3^{\mathrm{A}, \mathrm{b}}$ & $59.2^{\mathrm{C}, \mathrm{a}, \mathrm{b}}$ & $46.5^{\mathrm{A}, \mathrm{B}, \mathrm{c}}$ \\
& & & \\
& SEM $^{2}$ & Trt & Day & Trt x Day \\
\hline
\end{tabular}

A-EMeans with different superscripts in the same column indicate significance, $P<0.05$

${ }^{\mathrm{a}-\mathrm{d}}$ Means with different superscripts in the same row indicate significance, $P<0.05$

${ }^{1} \mathrm{CONT}=$ no additives; UREA $=$ applied at $5 \%$ of DM; SS $=$ a mixture of Enterococcus faecium M74, Lactococcus lactis SR3.54, and Lactobacillus plantarum CH6072 applied at $1.5 \times 10^{5} \mathrm{cfu} / \mathrm{fresh} \mathrm{g}$; CAO $=\mathrm{SS}$ and calcium oxide applied at $5 \%$ of DM.

${ }^{2} \mathrm{SEM}$, standard error of the mean

Table 7: Effects of applying 3 inoculants on mean acid detergent lignin (ADL, $\%$ ) concentration for olive pomace and ensiled for $2,10,60$, and $120 \mathrm{~d}$

\begin{tabular}{lcccc}
\hline & \multicolumn{4}{c}{ Treatment $^{\mathbf{1}}$} \\
\cline { 2 - 5 } Day & CONT & SS & UREA & CAO \\
\hline 0 & $43.5^{\mathrm{A}, \mathrm{a}}$ & $43.4^{\mathrm{A}, \mathrm{a}}$ & $43.9^{\mathrm{A}, \mathrm{C}, \mathrm{a}}$ & $34.9^{\mathrm{A}, \mathrm{b}}$ \\
2 & $41.9^{\mathrm{A}, \mathrm{a}}$ & $36.7^{\mathrm{B}, \mathrm{b}}$ & $37.6^{\mathrm{B}, \mathrm{b}}$ & $33.7^{\mathrm{A}, \mathrm{c}}$ \\
10 & $42.3^{\mathrm{A}, \mathrm{a}}$ & $43.3^{\mathrm{A}, \mathrm{a}}$ & $44.9^{\mathrm{A}, \mathrm{a}}$ & $35.0^{\mathrm{A}, \mathrm{b}}$ \\
60 & $43.4^{\mathrm{A}, \mathrm{a}}$ & $42.5^{\mathrm{A}, \mathrm{a}}$ & $41.6^{\mathrm{C}, \mathrm{a}}$ & $33.3^{\mathrm{A}, \mathrm{b}}$ \\
120 & $47.7^{\mathrm{B}, \mathrm{a}}$ & $44.0^{\mathrm{A}, \mathrm{b}}$ & $44.5^{\mathrm{A}, \mathrm{C}, \mathrm{b}}$ & $33.5^{\mathrm{A}, \mathrm{c}}$ \\
& & & & \\
& $\mathbf{S E M}^{\mathbf{2}}$ & Trt & Day & Trt $\mathbf{x}$ Day \\
\hline
\end{tabular}

${ }^{\mathrm{A}-\mathrm{E}}$ Means with different superscripts in the same column indicate significance, $P<0.05$

${ }^{\mathrm{a}-\mathrm{d}}$ Means with different superscripts in the same row indicate significance, $P<0.05$

${ }^{1} \mathrm{CONT}=$ no additives; $\mathrm{UREA}=$ applied at $5 \%$ of DM; SS $=$ a mixture of Enterococcus faecium M74, Lactococcus lactis SR3.54, and Lactobacillus plantarum CH6072 applied at $1.5 \times 10^{5} \mathrm{cfu} / \mathrm{fresh}$ g; CAO $=\mathrm{SS}$ and calcium oxide applied at $5 \%$ of DM.

${ }^{2} \mathrm{SEM}$, standard error of the mean 
Table 8: Effects of applying 3 inoculants on mean acid detergent lignin (ADL, $\%$ ) concentration for olive pomace and ensiled for 2, 10, 60, and $120 \mathrm{~d}$

\begin{tabular}{lcccc}
\hline & \multicolumn{4}{c}{ Treatment $^{1}$} \\
\cline { 2 - 5 } Day & CONT & SS & UREA & CAO \\
\hline 0 & $25.5^{\mathrm{A}, \mathrm{a}}$ & $22.4^{\mathrm{A}, \mathrm{b}}$ & $21.5^{\mathrm{A}, \mathrm{b}}$ & $17.11^{\mathrm{A}, \mathrm{c}}$ \\
2 & $23.8^{\mathrm{A}, \mathrm{a}}$ & $20.3^{\mathrm{B}, \mathrm{b}, \mathrm{c}}$ & $21.5^{\mathrm{A}, \mathrm{b}}$ & $19.2^{\mathrm{B}, \mathrm{c}}$ \\
10 & $24.7^{\mathrm{A}, \mathrm{a}}$ & $25.4^{\mathrm{C}, \mathrm{a}}$ & $25.9^{\mathrm{B}, \mathrm{a}}$ & $19.6^{\mathrm{B}, \mathrm{b}}$ \\
60 & $24.5^{\mathrm{A}, \mathrm{a}}$ & $25.7^{\mathrm{C}, \mathrm{a}}$ & $25.0^{\mathrm{B}, \mathrm{a}}$ & $17.1^{\mathrm{A}, \mathrm{b}}$ \\
120 & $25.4^{\mathrm{A}, \mathrm{a}}$ & $25.4^{\mathrm{C}, \mathrm{a}}$ & $24.9^{\mathrm{B}, \mathrm{a}}$ & $17.0^{\mathrm{A}, \mathrm{b}}$ \\
& & & & \\
& SEM $^{\mathbf{2}}$ & Trt & Day & Trt x Day \\
\cline { 2 - 5 } & 0.6201 & $<0.001$ & $<0.001$ & $<0.001$ \\
\hline
\end{tabular}

A-EMeans with different superscripts in the same column indicate significance, $P<0.05$

${ }^{\mathrm{a}-\mathrm{d}}$ Means with different superscripts in the same row indicate significance, $P<0.05$

${ }^{1} \mathrm{CONT}=$ no additives; UREA $=$ applied at $5 \%$ of DM; SS = a mixture of Enterococcus faecium M74, Lactococcus lactis SR3.54, and Lactobacillus plantarum $\mathrm{CH} 6072$ applied at $1.5 \times 10^{5} \mathrm{cfu} / \mathrm{fresh} \mathrm{g}$; CAO $=\mathrm{SS}$ and calcium oxide applied at $5 \%$ of DM.

${ }^{2} \mathrm{SEM}$, standard error of the mean

Table 9: Effects of applying 3 inoculants on mean crude protein (CP, \%) concentration for olive pomace and ensiled for $2,10,60$, and $120 \mathrm{~d}$

\begin{tabular}{lcccc}
\hline & \multicolumn{4}{c}{ Treatment $^{\mathbf{1}}$} \\
\cline { 2 - 5 } Day & CONT & SS & UREA & CAO \\
\hline 0 & $6.48^{\mathrm{A}, \mathrm{a}}$ & $5.58^{\mathrm{A}, \mathrm{a}}$ & $20.4^{\mathrm{A}, \mathrm{b}}$ & $5.80^{\mathrm{A}, \mathrm{a}}$ \\
2 & $6.10^{\mathrm{A}, \mathrm{a}}$ & $6.43^{\mathrm{A}, \mathrm{B}, \mathrm{C}, \mathrm{a}}$ & $19.2^{\mathrm{C}, \mathrm{b}}$ & $5.19^{\mathrm{A}, \mathrm{a}}$ \\
10 & $6.02^{\mathrm{A}, \mathrm{a}}$ & $6.28^{\mathrm{A}, \mathrm{C}, \mathrm{a}}$ & $21.8^{\mathrm{B}, \mathrm{b}}$ & $5.94^{\mathrm{A}, \mathrm{a}}$ \\
60 & $7.13^{\mathrm{A}, \mathrm{a}, \mathrm{c}}$ & $7.60^{\mathrm{B}, \mathrm{C}, \mathrm{a}}$ & $23.8^{\mathrm{D}, \mathrm{b}}$ & $6.10^{\mathrm{A}, \mathrm{c}}$ \\
120 & $7.08^{\mathrm{A}, \mathrm{a}, \mathrm{c}}$ & $7.42^{\mathrm{C}, \mathrm{a}}$ & $21.7^{\mathrm{B}, \mathrm{b}}$ & $6.12^{\mathrm{A}, \mathrm{c}}$ \\
& & & & \\
& SEM $^{\mathbf{2}}$ & Trt & Day & Trt x Day \\
\cline { 2 - 5 } & 0.429 & $<0.001$ & $<0.001$ & $<0.001$ \\
& & & &
\end{tabular}

A-EMeans with different superscripts in the same column indicate significance, $P<0.05$

${ }^{\mathrm{a}-\mathrm{d}}$ Means with different superscripts in the same row indicate significance, $P<0.05$

${ }^{1} \mathrm{CONT}=$ no additives; UREA $=$ applied at $5 \%$ of DM; SS $=$ a mixture of Enterococcus faecium M74, Lactococcus lactis SR3.54, and Lactobacillus plantarum CH6072 applied at $1.5 \times 10^{5} \mathrm{cfu} / \mathrm{fresh} \mathrm{g}$; CAO $=\mathrm{SS}$ and calcium oxide applied at $5 \%$ of DM.

${ }^{2} \mathrm{SEM}$, standard error of the mean 
Table 10: Effects of applying 3 inoculants on mean fat (\%) concentration for olive pomace and ensiled for $2,10,60$, and $120 \mathrm{~d}$

\begin{tabular}{|c|c|c|c|c|}
\hline \multirow[b]{2}{*}{ Day } & \multicolumn{4}{|c|}{ Treatment $^{1}$} \\
\hline & CONT & SS & UREA & CAO \\
\hline 0 & $12.9^{\mathrm{A}, \mathrm{a}}$ & $15.0^{\mathrm{A}, \mathrm{b}}$ & $14.5^{\mathrm{A}, \mathrm{b}}$ & $12.2^{\mathrm{A}, \mathrm{a}}$ \\
\hline 2 & $14.2^{\mathrm{A}}$ & $15.4^{\mathrm{A}, \mathrm{a}}$ & $12.8^{\mathrm{B}, \mathrm{b}}$ & $12.8^{\mathrm{A}, \mathrm{b}}$ \\
\hline 10 & $16.0^{\mathrm{B}, \mathrm{a}}$ & $17.5^{\mathrm{B}, \mathrm{a}}$ & $16.2^{\mathrm{C}, \mathrm{a}}$ & $11.9^{\mathrm{A}, \mathrm{b}}$ \\
\hline 60 & $13.3^{\mathrm{A}, \mathrm{a}}$ & $17.0^{\mathrm{B}, \mathrm{b}}$ & $14.4^{\mathrm{A}, \mathrm{a}}$ & $14.0^{\mathrm{B}, \mathrm{a}}$ \\
\hline \multirow[t]{3}{*}{120} & $12.6^{\mathrm{A}, \mathrm{a}}$ & $13.3^{\mathrm{C}, \mathrm{a}}$ & $11.8^{\mathrm{B}, \mathrm{a}}$ & $12.2^{\mathrm{A}, \mathrm{a}}$ \\
\hline & SEM $^{2}$ & Trt & Day & Trt x Day \\
\hline & 0.548 & $<0.001$ & $<0.001$ & $<0.001$ \\
\hline
\end{tabular}

A-EMeans with different superscripts in the same column indicate significance, $P<0.05$

${ }^{\mathrm{a}-\mathrm{d}}$ Means with different superscripts in the same row indicate significance, $P<0.05$

${ }^{1} \mathrm{CONT}=$ no additives; UREA $=$ applied at $5 \%$ of DM; SS $=$ a mixture of Enterococcus faecium M74, Lactococcus lactis SR3.54, and Lactobacillus plantarum CH6072 applied at $1.5 \times 10^{5} \mathrm{cfu} / \mathrm{fresh} \mathrm{g}$; CAO $=$ SS and calcium oxide applied at $5 \%$ of DM.

${ }^{2} \mathrm{SEM}$, standard error of the mean

Table 11: Effects of applying 3 inoculants on mean water-soluble carbohydrates (WSC, \%) concentration for olive pomace and ensiled for $2,10,60$, and $120 \mathrm{~d}$

\begin{tabular}{lcccc}
\hline & \multicolumn{4}{c}{ Treatment $^{1}$} \\
\cline { 2 - 5 } Day & CONT & SS & UREA & CAO \\
\hline 0 & $14.8^{\mathrm{A}, \mathrm{a}}$ & $19.6^{\mathrm{A}, \mathrm{b}}$ & $17.3^{\mathrm{A}, \mathrm{c}}$ & $13.5^{\mathrm{A}, \mathrm{a}}$ \\
2 & $13.1^{\mathrm{B}, \mathrm{a}}$ & $10.6^{\mathrm{B}, \mathrm{b}}$ & $11.0^{\mathrm{B}, \mathrm{b}}$ & $7.54^{\mathrm{B}, \mathrm{c}}$ \\
10 & $10.1^{\mathrm{C}, \mathrm{a}}$ & $12.1^{\mathrm{C}, \mathrm{b}}$ & $4.82^{\mathrm{C}, \mathrm{c}}$ & $7.96^{\mathrm{B}, \mathrm{d}}$ \\
60 & $5.58^{\mathrm{D}, \mathrm{a}}$ & $6.06^{\mathrm{D}, \mathrm{a}}$ & $5.14^{\mathrm{C}, \mathrm{a}}$ & $5.94^{\mathrm{C}, \mathrm{a}}$ \\
120 & $6.70^{\mathrm{D}, \mathrm{a}}$ & $6.35^{\mathrm{D}, \mathrm{a}, \mathrm{b}}$ & $4.98^{\mathrm{C}, \mathrm{b}}$ & $6.95^{\mathrm{B}, \mathrm{C}, \mathrm{a}}$ \\
& & & & \\
& SEM $^{\mathbf{2}}$ & Trt & Day & Trt x Day \\
\cline { 2 - 5 } & 0.519 & $<0.001$ & $<0.001$ & $<0.001$ \\
\hline
\end{tabular}

${ }^{\mathrm{A}-\mathrm{E}}$ Means with different superscripts in the same column indicate significance, $P<0.05$

${ }^{\mathrm{a}-\mathrm{d}}$ Means with different superscripts in the same row indicate significance, $P<0.05$

${ }^{1} \mathrm{CONT}=$ no additives; UREA $=$ applied at $5 \%$ of DM; SS $=$ a mixture of Enterococcus faecium M74, Lactococcus lactis SR3.54, and Lactobacillus plantarum CH6072 applied at $1.5 \times 10^{5} \mathrm{cfu} / \mathrm{fresh} \mathrm{g}$; CAO $=\mathrm{SS}$ and calcium oxide applied at $5 \%$ of DM.

${ }^{2} \mathrm{SEM}$, standard error of the mean 


\subsection{Fermentation Parameters}

Treating the olive pomace with SS, UREA, and CAO improved DM recovery after ensiling (Table 12). Silages treated with urea release ammonia which inhibit yeast and mold proliferation, leading to higher DM recovery and lower WSC (Schmidt, 2006); both effects observed in UREA samples. We found greater DM recovery in CAO versus CONT for all ensiling days; highest at 2 and $60 \mathrm{~d}$ of storage (100 and $100 \pm 0.114 \%$, respectively, $P<$ 0.001), similar to the findings of Jacovaci et al. (2017) with sugar cane silage. These findings could be partially explained by the ability for $\mathrm{CaO}$ to retain water and theoretically effluents (Chizzotti et al., 2015). The lower ethanol production observed at 10, 60, and 120 d compared to CONT $(0.266,0.313,0.609$ vs. $0.985,2.55,2.62 \pm 0.09 \%$ of DM, respectively, Table 14) and potential reduction in effluents contribute to the observed increase DM recovery (Santos et al., 2008; Cavali et al., 2010). Differences in pH between treatments and ensiling periods remained less than $1.0 \mathrm{pH}$ unit (Table 13), varying slightly around a $\mathrm{pH}$ of 5.7 with $\mathrm{CAO}$ having significantly higher $\mathrm{pH}$ levels $(P<0.05)$; higher than the ideal range of 3.8 to 4.2 for silages (McDonald et al., 1991). High pH levels observed in SS are unusual since microbial inoculation with homofermentative LAB should reduce $\mathrm{pH}$, acetic acid, and ammonia-N while increasing lactic acid (Kung Jr, 2011). Addition of urea or calcium oxide to the by-product of sweet corn both resulted in higher $\mathrm{pH}$ levels than the control after $50 \mathrm{~d}$ of ensiling (Vieira et al., 2017). Higher $\mathrm{pH}$ levels for calcium oxide-treated silages are primarily due to the alkaline nature of the product which resultin higher buffer capacity (Santos et al., 2008), hence, greater resistance to $\mathrm{pH}$ drop (Jacovavi et al., 2017; Vieira et al., 2017). Buffering capacity of forages is defined as the degree to which the product resists changes in $\mathrm{pH}$, resulting in more or less acid required to reduce 
the $\mathrm{pH}$ (Bujnak et al., 2011). This was observed for all olive pomace samples since $\mathrm{pH}$ levels never dropped to adequate silage levels (Table 13). For the UREA samples, the moisture content in the silo allowed for adequate conversion of urea into ammonium hydroxide which elevate the $\mathrm{pH}$ of the product and inhibit growth of undesirable microorganisms (Kung Jr. et al., 2003).

Lactic and acetic acid increased with prolonged ensiling (Table 15 and 16). UREA generally contained the most lactic acid and the least acetic acid throughout ensiling; over 3 times more lactic acid and almost 3 times less acetic acid than CONT at $120 \mathrm{~d}(0.716$ vs. $0.206 \pm 0.012,0.422$ vs. $1.15 \pm 0.057 \%$ of DM, respectively, $P<0.05$ ), indicating homolactic bacteria dominated fermentation. Contrary to previous findings in corn silage (Daniel et al., 2018), SS did not affect lactic and acetic acid, and ammonia concentrations $(P>0.05)$ but a higher ethanol concentration was observed by $60 \mathrm{~d}$ compared to CONT (3.05 vs. $2.55 \pm 0.09, P<0.001$ ). Meeske and Basson (1998) reported inoculation of maize crop with LAB to have no effect on lowering the $\mathrm{pH}$ or lactic acid concentration because of the naturally high $\mathrm{LAB}$ population found on the fresh product. The $\mathrm{NH}_{3}-\mathrm{N}$ concentration (as \% of total $\mathrm{N}$ ) fluctuated with ensiling for CONT and CAO; SS decreased while UREA increased $\mathrm{NH}_{3}-\mathrm{N}$ levels throughout ensiling (Table 17, $P<0.05$ ). The highest levels of $\mathrm{NH}_{3}-\mathrm{N}$ were observed with UREA at 10,60 , and $120 \mathrm{~d}(0.236,0.32$, and $0.391 \pm 0.011 \%$ of total $\mathrm{N}$, respectively), further supporting the benefits associated with improved DM recovery (Schmidt, 2006). Even so, $\mathrm{NH}_{3}-\mathrm{N}$ concentrations were lower than reported values in the literature for corn silages with 30-40\% DM, and reached levels below the Kung and Shaver (2001) threshold of $10 \%$ of CP. 
Ethanol concentrations increased with ensiling for all treatments with the highest levels observed by $120 \mathrm{~d}$ (Table 14). Addition of UREA resulted in significantly more ethanol production than CONT at 0,10 , and $120 \mathrm{~d}(0.419,2.24,3.00$ vs. $0.136,0.985,2.62$, respectively; $P=0.03, P<0.001, P=0.004$, respectively). The increase in ethanol production observed in ensiled SS and UREA is probably due to the relatively low acetic and undetectable propionic acid concentrations which inhibit ethanol-producing yeasts. By $10 \mathrm{~d}, \mathrm{CAO}$ had significantly less ethanol content than CONT, SS, and UREA, and the effect continued through $120 \mathrm{~d}$ (Table 14); associated with reduced yeast metabolism. Propionic acids, butyric acids, and 1,2 propanediol were not detectable for any treatment. No difference was observed in L:A for CONT, SS, and CAO across all ensiling days (Table $18, P>0.05)$. The L:A increased with ensiling for UREA and contained higher levels than CONT at 10,60 , and $120 \mathrm{~d}(1.18,1.77,1.71$ vs. $0.148,0.229,0.183 \pm 0.059 \%$ of DM, respectively, $P<0.001$ ), indicating a more homolactic fermentation. Similar findings were observed when using the homofermentation index, the ratio between lactic acid and the sum of acetic acid and ethanol (Xiccato et al., 1994), for UREA compared to CONT at the same ensiling days $(0.181,0.234,0.21$ vs. $0.064,0.052,0.055 \pm 0.008 \%$ of DM, respectively). Homofermentation index increased for UREA and decreased for CONT, SS, and CAO with prolonged ensiling (Table $19, P<0.05$ ). 
Table 12: Effects of applying 3 inoculants on mean dry matter recovery (DMR, $\%$ ) for olive pomace and ensiled for $2,10,60$, and $120 \mathrm{~d}$

\begin{tabular}{|c|c|c|c|c|}
\hline \multirow[b]{2}{*}{ Day } & \multicolumn{4}{|c|}{ Treatment $^{1}$} \\
\hline & CONT & SS & UREA & CAO \\
\hline 2 & $98.5^{\mathrm{A}, \mathrm{a}}$ & $98.6^{\mathrm{A}, \mathrm{a}}$ & $99.0^{\mathrm{A}, \mathrm{b}}$ & $100.0^{\mathrm{A}, \mathrm{c}}$ \\
\hline 10 & $97.2^{\mathrm{B}, \mathrm{a}}$ & $98.6^{\mathrm{A}, \mathrm{b}}$ & $98.3^{\mathrm{B}, \mathrm{b}}$ & $99.9^{\mathrm{B}, \mathrm{c}}$ \\
\hline 60 & $92.8^{\mathrm{C}, \mathrm{a}}$ & $98.2^{\mathrm{B}, \mathrm{b}}$ & $96.7^{\mathrm{C}, \mathrm{c}}$ & $100.0^{\mathrm{A}, \mathrm{d}}$ \\
\hline \multirow[t]{3}{*}{120} & $91.3^{\mathrm{D}, \mathrm{a}}$ & $98.7^{\mathrm{A}, \mathrm{b}}$ & $97.4^{\mathrm{D}, \mathrm{c}}$ & $99.8^{\mathrm{C}, \mathrm{d}}$ \\
\hline & SEM $^{2}$ & Trt & Day & Trt x Day \\
\hline & 0.114 & $<0.001$ & $<0.001$ & $<0.001$ \\
\hline
\end{tabular}

$\overline{\mathrm{A}-\mathrm{E}}$ Means with different superscripts in the same column indicate significance, $P<0.05$

${ }^{\mathrm{a}-\mathrm{d} M e a n s}$ with different superscripts in the same row indicate significance, $P<0.05$

${ }^{1} \mathrm{CONT}=$ no additives; UREA $=$ applied at $5 \%$ of DM; SS $=$ a mixture of Enterococcus faecium M74,

Lactococcus lactis SR3.54, and Lactobacillus plantarum CH6072 applied at $1.5 \times 10^{5} \mathrm{cfu} / \mathrm{fresh} \mathrm{g}$; CAO

$=\mathrm{SS}$ and calcium oxide applied at $5 \%$ of DM.

${ }^{2} \mathrm{SEM}$, standard error of the mean

Table 13: Effects of applying 3 inoculants on mean $\mathrm{pH}$ for olive pomace and ensiled for $2,10,60$, and $120 \mathrm{~d}$

\begin{tabular}{lcccc}
\hline & \multicolumn{3}{c}{ Treatment $^{1}$} \\
\cline { 2 - 5 } Day & CONT & SS & UREA & CAO \\
\hline 0 & $5.61^{\mathrm{A}}$ & $5.65^{\mathrm{a}}$ & $5.59^{\mathrm{A}, \mathrm{b}}$ & $6.13^{\mathrm{A}, \mathrm{c}}$ \\
2 & $5.79^{\mathrm{B}, \mathrm{a}}$ & $5.69^{\mathrm{A}, \mathrm{b}}$ & $5.72^{\mathrm{B}, \mathrm{b}}$ & $6.02^{\mathrm{B}, \mathrm{c}}$ \\
10 & $5.81^{\mathrm{B}, \mathrm{a}}$ & $5.66^{\mathrm{A}, \mathrm{b}}$ & $5.85^{\mathrm{C}, \mathrm{a}}$ & $6.00^{\mathrm{B}, \mathrm{c}}$ \\
60 & $5.71^{\mathrm{C}, \mathrm{a}}$ & $5.60^{\mathrm{B}, \mathrm{b}}$ & $5.80^{\mathrm{C}, \mathrm{c}}$ & $5.88^{\mathrm{C}, \mathrm{d}}$ \\
120 & $5.83^{\mathrm{B}, \mathrm{a}}$ & $5.69^{\mathrm{A}, \mathrm{b}}$ & $5.8^{\mathrm{C}, \mathrm{a}}$ & $5.73^{\mathrm{D}, \mathrm{d}}$ \\
& & & & \\
& SEM $^{\mathbf{2}}$ & Trt & Day & Trt x Day \\
\cline { 2 - 5 } & $0.02^{2}$ & $<0.001$ & $<0.001$ & $<0.001$ \\
\hline
\end{tabular}

${ }^{\mathrm{A}-\mathrm{E}}$ Means with different superscripts in the same column indicate significance, $P<0.05$

${ }^{\mathrm{a}-\mathrm{d}}$ Means with different superscripts in the same row indicate significance, $P<0.05$

${ }^{1} \mathrm{CONT}=$ no additives; UREA $=$ applied at $5 \%$ of DM; SS $=$ a mixture of Enterococcus faecium M74, Lactococcus lactis SR3.54, and Lactobacillus plantarum CH6072 applied at $1.5 \times 10^{5} \mathrm{cfu} / \mathrm{fresh} \mathrm{g} ; \mathrm{CAO}$ $=\mathrm{SS}$ and calcium oxide applied at $5 \%$ of DM.

${ }^{2} \mathrm{SEM}$, standard error of the mean 
Table 14: Effects of applying 3 inoculants on mean ethanol concentration for olive pomace and ensiled for $2,10,60$, and $120 \mathrm{~d}$

\begin{tabular}{lcccc}
\hline & \multicolumn{4}{c}{ Treatment $^{1}$} \\
\cline { 2 - 5 } Day & CONT & SS & UREA & CAO \\
\hline 0 & $0.136^{\mathrm{A}, \mathrm{a}}$ & $0.131^{\mathrm{A}, \mathrm{a}}$ & $0.419^{\mathrm{A}, \mathrm{b}}$ & $0.141^{\mathrm{A}, \mathrm{a}}$ \\
2 & $0.36^{\mathrm{A}, \mathrm{a}}$ & $0.393^{\mathrm{B}, \mathrm{a}}$ & $0.486^{\mathrm{A}, \mathrm{a}}$ & $0.295^{\mathrm{A}, \mathrm{a}}$ \\
10 & $0.985^{\mathrm{B}, \mathrm{a}}$ & $0.996^{\mathrm{C}, \mathrm{a}}$ & $2.24^{\mathrm{B}, \mathrm{b}}$ & $0.266^{\mathrm{A}, \mathrm{c}}$ \\
60 & $2.55^{\mathrm{C}, \mathrm{a}}$ & $3.05^{\mathrm{D}, \mathrm{b}}$ & $2.58^{\mathrm{C}, \mathrm{a}}$ & $0.313^{\mathrm{A}, \mathrm{c}}$ \\
120 & $2.62^{\mathrm{C}, \mathrm{a}}$ & $3.13^{\mathrm{D}, \mathrm{b}}$ & $3.00^{\mathrm{D}, \mathrm{b}}$ & $0.609^{\mathrm{B}, \mathrm{c}}$ \\
& & & & \\
& SEM $^{\mathbf{2}}$ & Trt & Day & Trt x Day \\
\hline & 0.090 & $<0.001$ & $<0.001$ & $<0.001$ \\
\hline
\end{tabular}

A-EMeans with different superscripts in the same column indicate significance, $P<0.05$

${ }^{\mathrm{a}-\mathrm{d}}$ Means with different superscripts in the same row indicate significance, $P<0.05$

${ }^{1} \mathrm{CONT}=$ no additives; UREA $=$ applied at $5 \%$ of DM; SS $=$ a mixture of Enterococcus faecium M74, Lactococcus lactis SR3.54, and Lactobacillus plantarum CH6072 applied at $1.5 \times 10^{5} \mathrm{cfu} / \mathrm{fresh} \mathrm{g}$; CAO $=\mathrm{SS}$ and calcium oxide applied at $5 \%$ of DM.

${ }^{2} \mathrm{SEM}$, standard error of the mean

Table 15: Effects of applying 3 inoculants on mean lactic acid concentration for olive pomace and ensiled for $2,10,60$, and $120 \mathrm{~d}$

\begin{tabular}{lcccc}
\hline & \multicolumn{4}{c}{ Treatment $^{\mathbf{1}}$} \\
\cline { 2 - 5 } Day & CONT & SS & UREA & CAO \\
\hline 0 & $0.107^{\mathrm{A}, \mathrm{a}}$ & $0.088^{\mathrm{A}, \mathrm{a}, \mathrm{b}}$ & $0.075^{\mathrm{A}, \mathrm{a}, \mathrm{b}}$ & $0.061^{\mathrm{A}, \mathrm{b}}$ \\
2 & $0.086^{\mathrm{A}, \mathrm{a}}$ & $0.087^{\mathrm{A}, \mathrm{a}}$ & $0.078^{\mathrm{A}, \mathrm{a}}$ & $0.108^{\mathrm{Ba}}$ \\
10 & $0.103^{\mathrm{A}, \mathrm{a}}$ & $0.103^{\mathrm{A}, \mathrm{a}}$ & $0.487^{\mathrm{B}, \mathrm{b}}$ & $0.13^{\mathrm{B}, \mathrm{a}}$ \\
60 & $0.174^{\mathrm{B}, \mathrm{a}}$ & $0.18^{\mathrm{B}, \mathrm{a}}$ & $0.694^{\mathrm{C}, \mathrm{b}}$ & $0.168^{\mathrm{C}, \mathrm{a}}$ \\
120 & $0.206^{\mathrm{B}, \mathrm{a}}$ & $0.263^{\mathrm{C}, \mathrm{b}}$ & $0.716^{\mathrm{C}, \mathrm{c}}$ & $0.113^{\mathrm{B}, \mathrm{d}}$ \\
& & & & \\
& SEM $^{2}$ & Trt & Day & Trt x Day \\
\cline { 2 - 5 } & $0.012^{2}$ & $<0.001$ & $<0.001$ & $<0.001$ \\
\hline
\end{tabular}

A-E Means with different superscripts in the same column indicate significance, $P<0.05$

${ }^{\mathrm{a}-\mathrm{d}}$ Means with different superscripts in the same row indicate significance, $P<0.05$

${ }^{1} \mathrm{CONT}=$ no additives; UREA $=$ applied at $5 \%$ of DM; SS $=$ a mixture of Enterococcus faecium M74, Lactococcus lactis SR3.54, and Lactobacillus plantarum CH6072 applied at $1.5 \times 10^{5} \mathrm{cfu} / \mathrm{fresh} \mathrm{g}$; CAO $=\mathrm{SS}$ and calcium oxide applied at $5 \%$ of DM.

${ }^{2} \mathrm{SEM}$, standard error of the mean 
Table 16: Effects of applying 3 inoculants on mean acetic acid concentration for olive pomace and ensiled for $2,10,60$, and $120 \mathrm{~d}$

\begin{tabular}{lcccc}
\hline & \multicolumn{4}{c}{ Treatment $^{1}$} \\
\cline { 2 - 5 } Day & CONT & SS & UREA $^{\mathrm{A}, \mathrm{b}}$ & CAO \\
\hline 0 & $0.977^{\mathrm{A}, \mathrm{a}}$ & $0.688^{\mathrm{b}} \mathrm{b}$ & $0.42^{\mathrm{A}, \mathrm{c}}$ & $0.544^{\mathrm{A}, \mathrm{b}, \mathrm{c}}$ \\
2 & $0.587^{\mathrm{B}, \mathrm{a}}$ & $0.59^{\mathrm{A}, \mathrm{B}, \mathrm{a}}$ & $0.35^{\mathrm{A}, \mathrm{b}}$ & $1.27^{\mathrm{B}, \mathrm{c}}$ \\
10 & $0.709^{\mathrm{B}, \mathrm{C}, \mathrm{a}}$ & $0.799^{\mathrm{A}, \mathrm{C}, \mathrm{a}}$ & $0.417^{\mathrm{A}, \mathrm{b}}$ & $1.63^{\mathrm{C}, \mathrm{c}}$ \\
60 & $0.763^{\mathrm{C}, \mathrm{a}}$ & $0.94^{\mathrm{C}, \mathrm{b}}$ & $0.424^{\mathrm{A}, \mathrm{c}}$ & $2.2^{\mathrm{D}, \mathrm{d}}$ \\
120 & $1.15^{\mathrm{D}, \mathrm{a}}$ & $1.24^{\mathrm{D}, \mathrm{a}}$ & $0.422^{\mathrm{A}, \mathrm{b}}$ & $2.18^{\mathrm{D}, \mathrm{c}}$ \\
& & & & \\
& & Trt & Day & Trt x Day \\
\hline & SEM $^{2}$ & $<0.001$ & $<0.001$ & $<0.001$ \\
\hline
\end{tabular}

A-EMeans with different superscripts in the same column indicate significance, $P<0.05$

${ }^{\mathrm{a}-\mathrm{d}}$ Means with different superscripts in the same row indicate significance, $P<0.05$

${ }^{1} \mathrm{CONT}=$ no additives; UREA $=$ applied at $5 \%$ of DM; SS $=$ a mixture of Enterococcus faecium M74, Lactococcus lactis SR3.54, and Lactobacillus plantarum CH6072 applied at $1.5 \times 10^{5} \mathrm{cfu} / \mathrm{fresh} \mathrm{g}$; CAO $=\mathrm{SS}$ and calcium oxide applied at $5 \%$ of DM.

${ }^{2} \mathrm{SEM}$, standard error of the mean

Table 17: Effects of applying 3 inoculants on mean ammonia-nitrogen (NH3-N, $\%$ of total nitrogen) concentration for olive pomace and ensiled for $2,10,60$, and $120 \mathrm{~d}$

\begin{tabular}{lcccc}
\hline & \multicolumn{4}{c}{ Treatment $^{1}$} \\
\cline { 2 - 5 } Day & CONT & SS & UREA $^{\mathrm{A}}$ & CAO \\
\hline 0 & $0.163^{\mathrm{A}, \mathrm{a}}$ & $0.254^{\mathrm{A}, \mathrm{b}}$ & $0.107^{\mathrm{A}, \mathrm{c}}$ & $0.082^{\mathrm{A}, \mathrm{c}}$ \\
2 & $0.205^{\mathrm{B}, \mathrm{a}}$ & $0.172^{\mathrm{B}, \mathrm{a}, \mathrm{b}}$ & $0.182^{\mathrm{B}, \mathrm{a}, \mathrm{b}}$ & $0.161^{\mathrm{B}, \mathrm{b}}$ \\
10 & $0.176^{\mathrm{A}, \mathrm{B}, \mathrm{a}}$ & $0.149^{\mathrm{B}, \mathrm{a}, \mathrm{c}}$ & $0.236^{\mathrm{C}, \mathrm{b}}$ & $0.138^{\mathrm{B}, \mathrm{C}, \mathrm{c}}$ \\
60 & $0.085^{\mathrm{C}, \mathrm{a}}$ & $0.100^{\mathrm{C}, \mathrm{a}}$ & $0.32^{\mathrm{D}, \mathrm{b}}$ & $0.089^{\mathrm{A}, \mathrm{a}}$ \\
120 & $0.12^{\mathrm{D}, \mathrm{a}, \mathrm{c}}$ & $0.087^{\mathrm{C}, \mathrm{a}}$ & $0.391^{\mathrm{E}, \mathrm{b}}$ & $0.123^{\mathrm{C}, \mathrm{c}}$ \\
& & & \\
& & & Day & Trt $^{\mathbf{T}}$ Day \\
\hline
\end{tabular}

\footnotetext{
A-E Means with different superscripts in the same column indicate significance, $P<0.05$

${ }^{\mathrm{a}-\mathrm{d}}$ Means with different superscripts in the same row indicate significance, $P<0.05$

${ }^{1} \mathrm{CONT}=$ no additives; UREA $=$ applied at $5 \%$ of DM; SS $=$ a mixture of Enterococcus faecium M74, Lactococcus lactis SR3.54, and Lactobacillus plantarum CH6072 applied at $1.5 \times 10^{5} \mathrm{cfu} / \mathrm{fresh} \mathrm{g}$; CAO $=\mathrm{SS}$ and calcium oxide applied at $5 \%$ of DM.

${ }^{2} \mathrm{SEM}$, standard error of the mean
} 
Table 18: Effects of applying 3 inoculants on mean lactic acid to acetic acid ratio (L:A) for olive pomace and ensiled for $2,10,60$, and $120 \mathrm{~d}$

\begin{tabular}{lcccc}
\hline & & \multicolumn{2}{c}{ Treatment $^{1}$} \\
\cline { 2 - 5 } Day & CONT & SS & UREA $^{\mathrm{A}, \mathrm{a}}$ & CAO \\
\hline 0 & $0.110^{\mathrm{A}, \mathrm{a}}$ & $0.130^{\mathrm{A}}$ & $0.178^{\mathrm{A}, \mathrm{a}}$ & $0.113^{\mathrm{A}, \mathrm{a}}$ \\
2 & $0.153^{\mathrm{A}, \mathrm{a}}$ & $0.151^{\mathrm{A}, \mathrm{a}}$ & $0.223^{\mathrm{A}, \mathrm{a}}$ & $0.085^{\mathrm{A}, \mathrm{a}}$ \\
10 & $0.148^{\mathrm{A}, \mathrm{a}}$ & $0.129^{\mathrm{A}, \mathrm{a}}$ & $1.18^{\mathrm{B}, \mathrm{b}}$ & $0.079^{\mathrm{A}, \mathrm{a}}$ \\
60 & $0.229^{\mathrm{A}, \mathrm{a}}$ & $0.192^{\mathrm{A}, \mathrm{a}}$ & $1.77^{\mathrm{C}, \mathrm{b}}$ & $0.079^{\mathrm{A}, \mathrm{a}}$ \\
120 & $0.183^{\mathrm{A}, \mathrm{a}}$ & $0.214^{\mathrm{A}, \mathrm{a}}$ & $1.71^{\mathrm{C}, \mathrm{b}}$ & $0.052^{\mathrm{A}, \mathrm{a}}$ \\
& & & & \\
& SEM $^{\mathbf{2}}$ & Trt & Day & Trt x Day \\
\cline { 2 - 5 } & 0.059 & $<0.001$ & $<0.001$ & $<0.001$ \\
\hline
\end{tabular}

$\overline{A-E}$ Means with different superscripts in the same column indicate significance, $P<0.05$

${ }^{\mathrm{a}-\mathrm{d}}$ Means with different superscripts in the same row indicate significance, $P<0.05$

${ }^{1} \mathrm{CONT}=$ no additives; UREA $=$ applied at $5 \%$ of DM; SS = a mixture of Enterococcus faecium M74, Lactococcus lactis SR3.54, and Lactobacillus plantarum CH6072 applied at $1.5 \times 10^{5} \mathrm{cfu} / \mathrm{fresh}$ g; CAO $=\mathrm{SS}$ and calcium oxide applied at $5 \%$ of DM.

${ }^{2} \mathrm{SEM}$, standard error of the mean

Table 19: Effects of applying 3 inoculants on mean homolactic index for olive pomace and ensiled for $2,10,60$, and $120 \mathrm{~d}$

\begin{tabular}{lcccc}
\hline & & \multicolumn{2}{c}{ Treatment $^{1}$} \\
\cline { 2 - 5 } Day & CONT & SS & UREA & CAO \\
\hline 0 & $0.098^{\mathrm{A}, \mathrm{a}}$ & $0.109^{\mathrm{A}, \mathrm{a}}$ & $0.089^{\mathrm{A}, \mathrm{a}}$ & $0.090^{\mathrm{A}, \mathrm{a}}$ \\
2 & $0.094^{\mathrm{A}, \mathrm{a}}$ & $0.091^{\mathrm{A}, \mathrm{a}, \mathrm{c}}$ & $0.094^{\mathrm{A}, \mathrm{b}}$ & $0.067^{\mathrm{A}, \mathrm{c}}$ \\
10 & $0.064^{\mathrm{B}, \mathrm{a}}$ & $0.058^{\mathrm{B}, \mathrm{a}}$ & $0.181^{\mathrm{B}, \mathrm{b}}$ & $0.068^{\mathrm{A}, \mathrm{a}}$ \\
60 & $0.052^{\mathrm{B}, \mathrm{a}, \mathrm{c}}$ & $0.045^{\mathrm{B}, \mathrm{a}}$ & $0.234^{\mathrm{C}, \mathrm{b}}$ & $0.068^{\mathrm{A}, \mathrm{c}}$ \\
120 & $0.055^{\mathrm{B}, \mathrm{a}}$ & $0.060^{\mathrm{B}, \mathrm{a}}$ & $0.21^{\mathrm{D}, \mathrm{b}}$ & $0.041^{\mathrm{B}, \mathrm{a}}$ \\
& & & & \\
& SEM$^{\mathbf{2}}$ & Trt & Day & Trt x Day \\
\cline { 2 - 5 } & $0.008^{2}$ & $<0.001$ & 0.203 & $<0.001$ \\
\hline
\end{tabular}

A-EMeans with different superscripts in the same column indicate significance, $P<0.05$

${ }^{\mathrm{a}-\mathrm{d}}$ Means with different superscripts in the same row indicate significance, $P<0.05$

${ }^{1} \mathrm{CONT}=$ no additives; UREA $=$ applied at $5 \%$ of DM; SS $=$ a mixture of Enterococcus faecium M74, Lactococcus lactis SR3.54, and Lactobacillus plantarum CH6072 applied at $1.5 \times 10^{5} \mathrm{cfu} / \mathrm{fresh} \mathrm{g}$; CAO $=\mathrm{SS}$ and calcium oxide applied at $5 \%$ of DM.

${ }^{2} \mathrm{SEM}$, standard error of the mean 


\subsubsection{Silage Microbial Populations}

We observed a higher population of LAB (Table 20) in SS than CONT from 10 to 120 d (7.43, 8.5, 7.08 vs. 7.36, 6.4, $6.01 \pm 0.018 \log$ cfu/fresh g, respectively $\mathrm{P}<0.05)$ suggesting the establishment of the inoculant bacteria (Enterococcus faecium M74, Lactococcus lactis SR3.54, and Lactobacillus plantarum CH6072), although LAB counts did not significantly increase with prolonged ensiling; maxing out at $8.5 \pm 0.018 \log \mathrm{cfu} /$ fresh $\mathrm{g}$ at $60 \mathrm{~d}$.

Mold and yeasts counts (log cfu/ fresh g) significantly decreased with prolonged ensiling for all treatments (Table 21 and 22, respectively, $\mathrm{P}<0.05$ ). Mold counts were not biologically different among treatments at $0 \mathrm{~d}(\sim 2.8 \log \mathrm{cfu} /$ fresh $\mathrm{g})$. After $120 \mathrm{~d}$, no mold colonies were detected above the minimum counting limit; CONT and UREA reached this limit by $60 \mathrm{~d}$ and SS by $10 \mathrm{~d}$ (Table 21). The delayed reduction in mold counts for CAO to $60 \mathrm{~d}$ can be explained by the resistant $\mathrm{pH}$ drop and lack of propionic acids which failed to reduce molds (Oladosu et al., 2016). Treating with CAO resulted in significantly fewer yeast counts at all ensiling days than CONT (Table 22, $\mathrm{P}<0.05$ ) with the lowest levels observed at $120 \mathrm{~d}(4.7754 \pm 0.03 \mathrm{log}$ cfu/ fresh g); potentially explaining the reduced ethanol production through reduced yeast metabolism. The lower population of yeast in CAO samples are a consequence of higher acetic acid concentrations (Table 16), although a lower population of mold was not observed when compared to CONT. Acetic acids can penetrate the membranes of yeasts and molds in silages where $\mathrm{pH}$ is low (around 4.0), releasing hydrogen ions and causing yeast homeostasis (Danner et al., 2003). Higher pH levels observed in CAO samples (Table 13) could have reduced the antimicrobial action of the acetic acids resulting in a lack of mold population reduction by $120 \mathrm{~d}$ (Table 21). 
Table 20: Effects of applying 3 inoculants on mean lactic acid bacteria (LAB, log $\mathrm{cfu} / \mathrm{g}$ FM) counts of fresh olive pomace and ensiled for 2, 10, 60, and $120 \mathrm{~d}$

\begin{tabular}{lcccc}
\hline & \multicolumn{3}{c}{ Treatment $^{\mathbf{1}}$} \\
\cline { 2 - 5 } Day & CONT & SS & UREA & CAO \\
\hline 0 & $7.14^{\mathrm{A}, \mathrm{b}}$ & $7.07^{\mathrm{A}, \mathrm{c}}$ & $6.95^{\mathrm{A}, \mathrm{D}, \mathrm{d}}$ & $6.64^{\mathrm{A}, \mathrm{a}}$ \\
2 & $7.15^{\mathrm{A}, \mathrm{a}}$ & $7.17^{\mathrm{B}, \mathrm{a}}$ & $6.9^{\mathrm{A}, \mathrm{b}}$ & $6.79^{\mathrm{B}, \mathrm{c}}$ \\
10 & $7.36^{\mathrm{B}, \mathrm{b}}$ & $7.43^{\mathrm{C}, \mathrm{c}}$ & $7.16^{\mathrm{B}, \mathrm{d}}$ & $7.26^{\mathrm{C}, \mathrm{a}}$ \\
60 & $6.4^{\mathrm{C}, \mathrm{a}}$ & $8.5^{\mathrm{D}, \mathrm{d}}$ & $7.75^{\mathrm{C}, \mathrm{c}}$ & $6.17^{\mathrm{D}}$ \\
120 & $6.01^{\mathrm{D}, \mathrm{a}}$ & $7.08^{\mathrm{A}, \mathrm{b}}$ & $6.98^{\mathrm{D}, \mathrm{c}}$ & $5.85^{\mathrm{E}, \mathrm{a}}$ \\
& & & & \\
& SEM $^{2}$ & Trt & Day & Trt x Day \\
\cline { 2 - 5 } & 0.018 & $<0.001$ & $<0.001$ & $<0.001$ \\
\hline
\end{tabular}

$\overline{\mathrm{A}-\mathrm{E}}$ Means with different superscripts in the same column indicate significance, $P<0.05$

${ }^{\mathrm{a}-\mathrm{d}}$ Means with different superscripts in the same row indicate significance, $P<0.05$

${ }^{1} \mathrm{CONT}=$ no additives; UREA $=$ applied at $5 \%$ of DM; $\mathrm{SS}=$ a mixture of Enterococcus faecium M74,

Lactococcus lactis SR3.54, and Lactobacillus plantarum CH6072 applied at $1.5 \times 10^{5} \mathrm{cfu} / \mathrm{fresh} \mathrm{g}$; CAO

$=\mathrm{SS}$ and calcium oxide applied at $5 \%$ of DM.

${ }^{2} \mathrm{SEM}$, standard error of the mean

Table 21: Effects of applying 3 inoculants on mean mold (log cfu/g FM) counts of fresh olive pomace and ensiled for $2,10,60$, and $120 \mathrm{~d}$

\begin{tabular}{lcccc}
\hline & \multicolumn{3}{c}{ Treatment $^{\mathbf{1}}$} \\
\cline { 2 - 5 } Day & CONT & SS & UREA & CAO \\
\hline 0 & $2.86^{\mathrm{A}, \mathrm{a}}$ & $2.87^{\mathrm{A}, \mathrm{a}}$ & $2.88^{\mathrm{A}, \mathrm{a}}$ & $2.88^{\mathrm{A}, \mathrm{a}}$ \\
2 & $2.8^{\mathrm{B}, \mathrm{a}}$ & $2.78^{\mathrm{B}, \mathrm{b}}$ & $2.85^{\mathrm{B}, \mathrm{a}, \mathrm{c}}$ & $2.87^{\mathrm{A}, \mathrm{c}}$ \\
10 & $2.57^{\mathrm{C}, \mathrm{a}}$ & $0^{\mathrm{C}, \mathrm{b}}$ & $2.64^{\mathrm{C}, \mathrm{c}}$ & $2.67^{\mathrm{B}, \mathrm{d}}$ \\
60 & $0^{\mathrm{D}, \mathrm{a}}$ & $0^{\mathrm{C}, \mathrm{a}}$ & $00^{\mathrm{D}, \mathrm{a}}$ & $2.54^{\mathrm{C}, \mathrm{b}}$ \\
120 & $0^{\mathrm{D}, \mathrm{a}}$ & $0^{\mathrm{C}, \mathrm{a}}$ & $0^{\mathrm{D}, \mathrm{a}}$ & $0^{\mathrm{D}, \mathrm{a}}$ \\
& & & & \\
& SEM$^{\mathbf{2}}$ & Trt & Day & Trt $\mathbf{x}$ Day \\
\cline { 2 - 5 } & 0.007 & $<0.001$ & $<0.001$ & $<0.001$ \\
\hline
\end{tabular}

${ }^{\mathrm{A}-\mathrm{E}}$ Means with different superscripts in the same column indicate significance, $P<0.05$

${ }^{\mathrm{a}-\mathrm{d}}$ Means with different superscripts in the same row indicate significance, $P<0.05$

${ }^{1} \mathrm{CONT}=$ no additives; UREA $=$ applied at $5 \%$ of DM; SS $=$ a mixture of Enterococcus faecium M74, Lactococcus lactis SR3.54, and Lactobacillus plantarum CH6072 applied at $1.5 \times 10^{5} \mathrm{cfu} / \mathrm{fresh}$ g; CAO $=\mathrm{SS}$ and calcium oxide applied at 5\% of DM.

${ }^{2} \mathrm{SEM}$, standard error of the mean 
Table 22: Effects of applying 3 inoculants on mean yeast $(\log \mathrm{cfu} / \mathrm{g}$ FM) counts of fresh olive pomace and ensiled for $2,10,60$, and $120 \mathrm{~d}$

\begin{tabular}{lcccc}
\hline & \multicolumn{3}{c}{ Treatment $^{\mathbf{1}}$} \\
\cline { 2 - 5 } Day & CONT & SS & UREA & CAO \\
\hline 0 & $7.03^{\mathrm{A}, \mathrm{a}}$ & $7.0^{\mathrm{A}, \mathrm{a}}$ & $6.81^{\mathrm{A}, \mathrm{b}}$ & $6.58^{\mathrm{A}, \mathrm{c}}$ \\
2 & $6.41^{\mathrm{B}, \mathrm{a}}$ & $6.39^{\mathrm{B}, \mathrm{a}}$ & $6.64^{\mathrm{B}, \mathrm{b}}$ & $6.22^{\mathrm{B}, \mathrm{c}}$ \\
10 & $6.0^{\mathrm{C}, \mathrm{b}}$ & $5.58^{\mathrm{B}, \mathrm{c}}$ & $6.06^{\mathrm{C}, \mathrm{b}}$ \\
60 & $6.21^{\mathrm{C}, \mathrm{a}}$ & $5.51^{\mathrm{D}, \mathrm{b}}$ & $5.99^{\mathrm{C}, \mathrm{c}}$ & $5.13^{\mathrm{D}, \mathrm{d}}$ \\
120 & $5.73^{\mathrm{D}, \mathrm{a}}$ & $5.39^{\mathrm{E}, \mathrm{b}}$ & $5.93^{\mathrm{C}, \mathrm{c}}$ & $4.78^{\mathrm{E}, \mathrm{d}}$ \\
& $5.55^{\mathrm{E}, \mathrm{a}}$ & & & \\
& & Trt & Day & Trt x Day \\
\cline { 2 - 5 } & SEM $^{2}$ & $<0.001$ & $<0.001$ & $<0.001$ \\
\hline
\end{tabular}

$\overline{\mathrm{A}-\mathrm{E}}$ Means with different superscripts in the same column indicate significance, $P<0.05$

${ }^{\mathrm{a}-\mathrm{d}}$ Means with different superscripts in the same row indicate significance, $P<0.05$

${ }^{1} \mathrm{CONT}=$ no additives; UREA $=$ applied at $5 \%$ of DM; $\mathrm{SS}=$ a mixture of Enterococcus faecium M74,

Lactococcus lactis SR3.54, and Lactobacillus plantarum CH6072 applied at $1.5 \times 10^{5} \mathrm{cfu} / \mathrm{fresh} \mathrm{g}$; CAO

$=\mathrm{SS}$ and calcium oxide applied at $5 \%$ of DM.

${ }^{2} \mathrm{SEM}$, standard error of the mean

\subsubsection{Aerobic Stability}

Aerobic stability of the treated olive pomace samples at each ensiling day is presented in the figures below. Each figure represents the difference in temperature $(\mathrm{C})$ between the average ambient and the average sample temperatures over hours of exposure. 


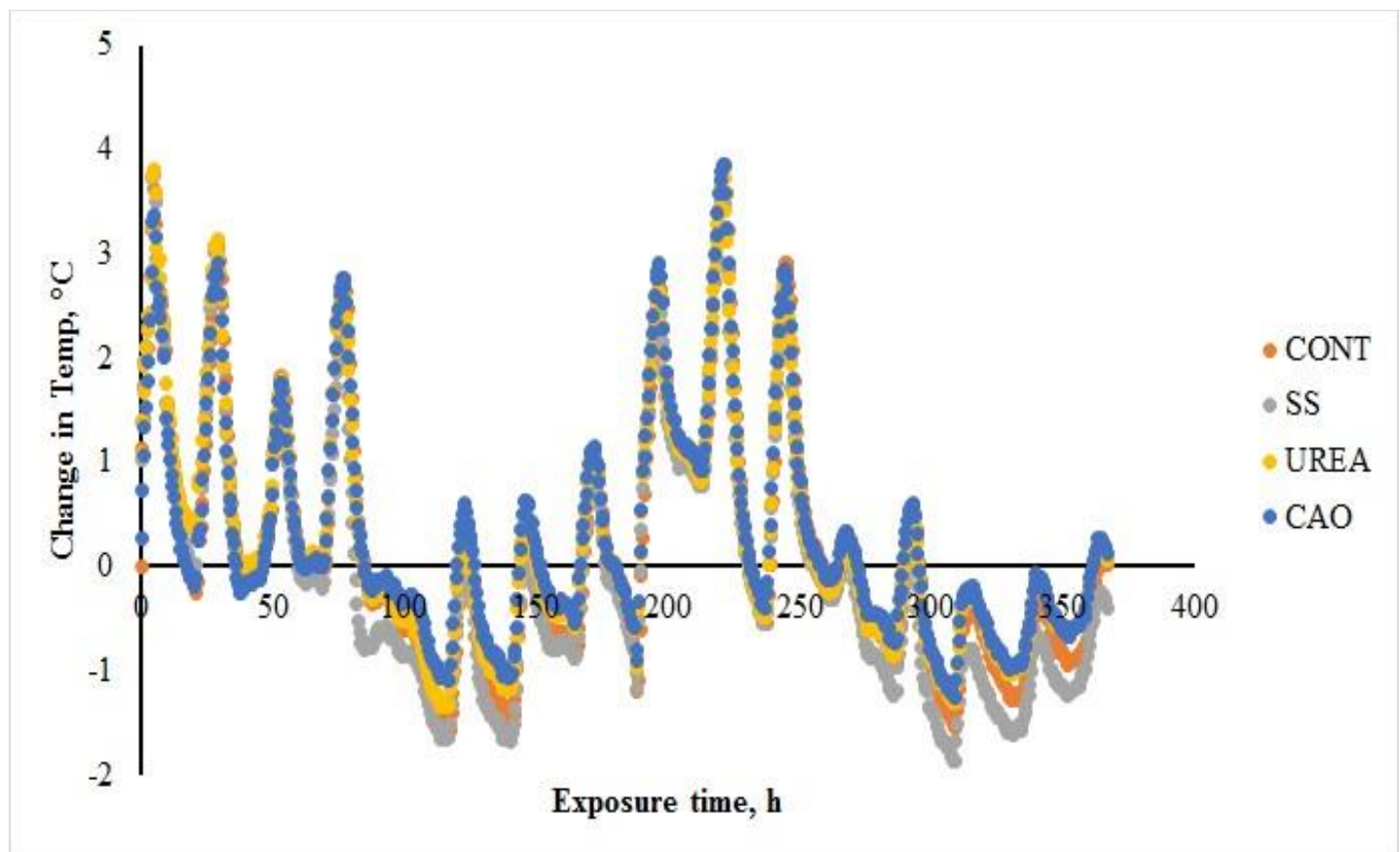

Figure 8: Difference in temperature between ambient and treated olive pomace samples ensiled for $2 \mathrm{~d}$.

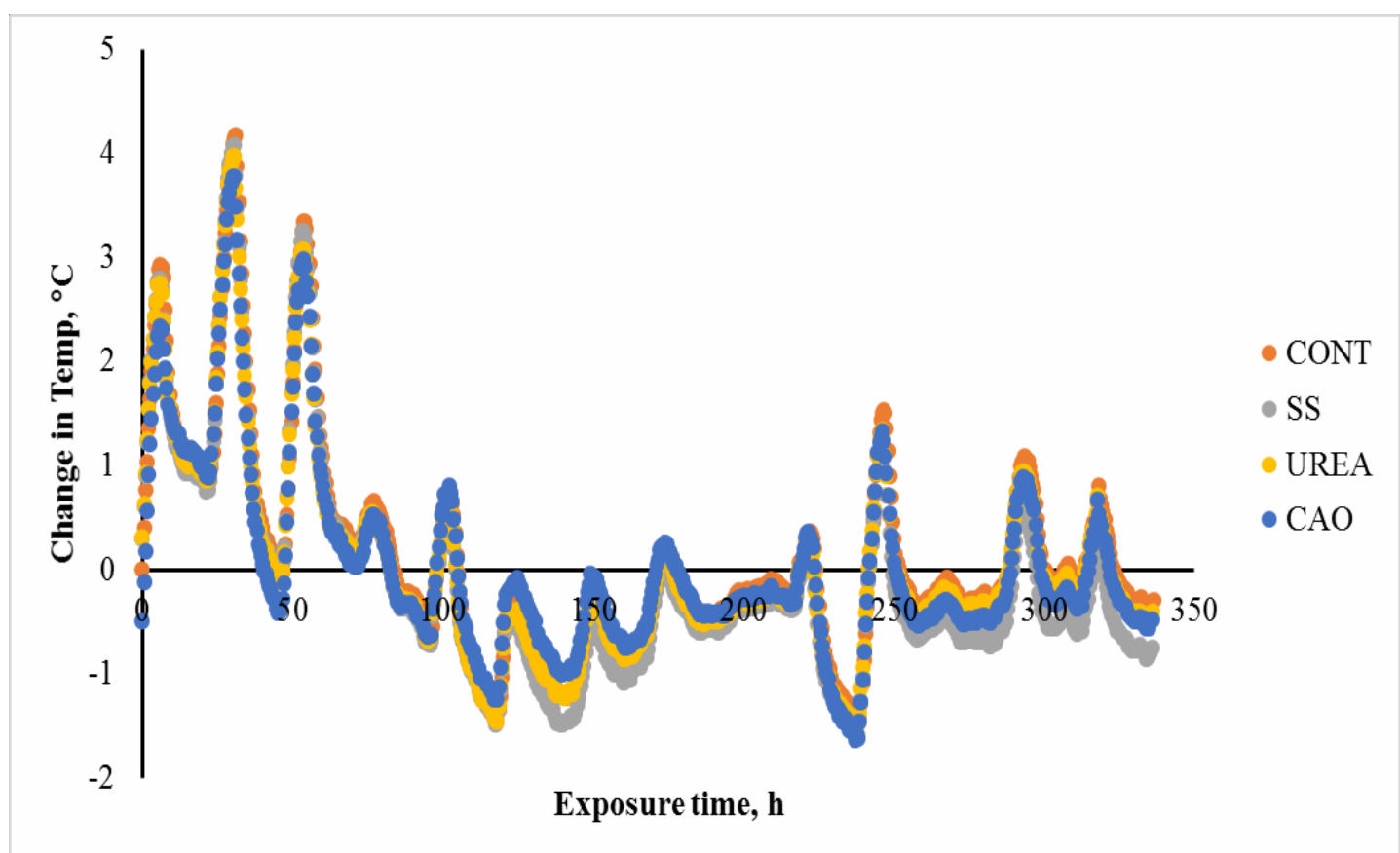

Figure 9: Difference in temperature between ambient and treated olive pomace samples ensiled for $10 \mathrm{~d}$. 


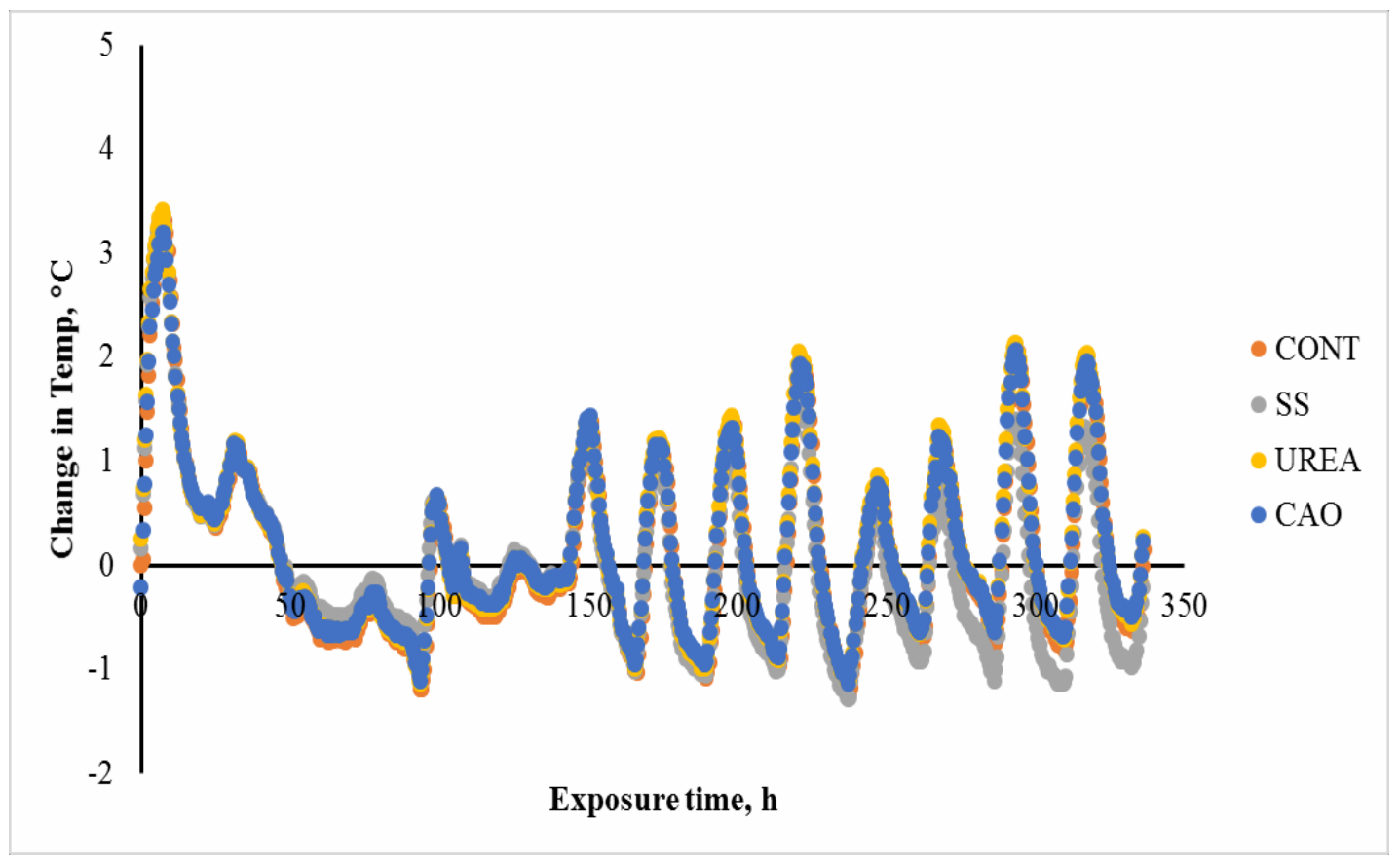

Figure 10: Difference in temperature between ambient and treated olive pomace samples ensiled for $60 \mathrm{~d}$.

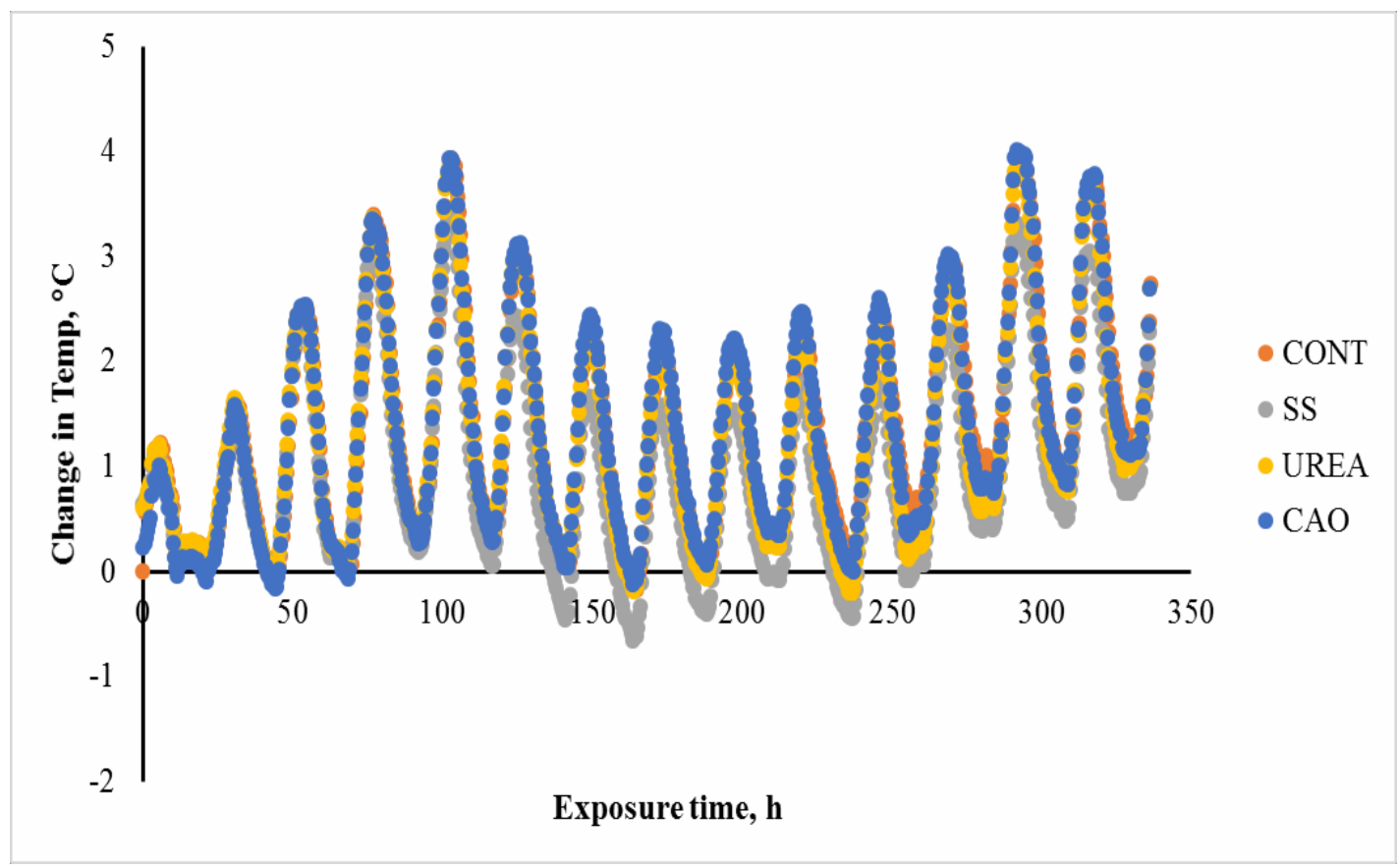

Figure 11: Difference in temperature between ambient and treated olive pomace samples ensiled for $120 \mathrm{~d}$. 
All treatments demonstrated similar results in terms of the difference in sample temperature to the ambient temperature. The accepted difference of $2^{\circ} \mathrm{C}$ was observed in all samples for 2, 10, and $60 \mathrm{~d}$ within 3 hours of exposure but this difference was reduced within a few additional hours. This fluctuation continues to be observed approximately every $24 \mathrm{~h}$. For $120 \mathrm{~d}$, a greater than $2^{\circ} \mathrm{C}$ change was not observed until $50 \mathrm{~h}$ of exposure for all treatments, but like the other ensiling days, it fluctuated thereafter.

Although the $2^{\circ} \mathrm{C}$ change in temperature was observed early on for 3 of the ensiled time periods, this does not necessarily mean that the olive pomace samples deteriorated upon exposure. Since the room in which the mini-silos were kept was not effectively controlled for normal temperature changes occurring during the course of the day $(24 \mathrm{~h})$, the sample temperatures fluctuated according to the ambient temperature changes, but later returned to similar temperatures. At $120 \mathrm{~d}$, the change in temperature was observed at a much later time, meaning that prolonged ensiling does improve aerobic stability of the treated olive pomace compared to the other ensiling days. All olive pomace samples showed no drastic increase in temperature representative of the onset of spoilage and little to no spoilage was actually detected upon opening of the mini-silos. This can suggest that the olive pomace samples were stable for a period of time after exposure to ambient environment, yet this particular data should be disregarded due to the ineffectiveness of a controlled ambient temperature during the duration of ensiling.

\subsection{In Situ Digestibility}

There were significant interactions between treatment and ensiling period $(P<0.0001)$ and treatment and in situ time $(P<0.001)$. Dry matter digestibilities (DMD) of the treated 
olive pomace samples at different in situ times, expressed as least square means, are reported below (Table 23). There was no difference observed among treatments at $12 \mathrm{~h}$ in situ $(P>0.05)$, but all treatments resulted in a significant increase in DMD from 12 to 24 to $48 \mathrm{~h}$ in situ $(P<0.05)$. At $24 \mathrm{~h}$, UREA showed significantly more DMD at $16.6736 \%$ than all other treatments $(P<0.02)$ but this effect diminished by $48 \mathrm{~h}$ where no difference was observed between UREA and CONT $(P>0.05)$. CAO had significantly less DMD than all other treatments at $48 \mathrm{~h}$ in situ $(20.338 \%, P<0.001)$.

A significant interaction between treatment and ensiling period $(P<0.001)$ and treatment and incubation period $(P<0.001)$ was observed. The NDFD of the treated olive pomace samples at different in situ times, expressed as least square means, are reported below (Table 24). At $12 \mathrm{~h}$, no difference in NDFD was observed among all treatments compared to the CONT $(P>0.05)$. By $24 \mathrm{~h}$ of incubation, none of the inoculants showed increased NDFD compared to the CONT $(P>0.05)$ although UREA did significantly differ than SS and CONT $(21.47,18.5,18.5 \pm 0.018 \%$ of DM, respectively). Although biologically meaningful digestibility values would be those at 12 and $24 \mathrm{~h}$ of incubation, $48 \mathrm{~h}$ digestibilities showed significant effects (Table 24). SS did not differ from CONT ( $P$ $=0.092)$ but UREA and CAO exhibited lower digestibilities (26.27 and $25.21 \pm 0.018 \%$ of $\mathrm{DM}$, respectively). Addition of $\mathrm{CaO}$ elevates the $\mathrm{pH}$ of the product, reducing the strength of inter-molecular bonds between hemicellulose and lignin, resulting in cellulose swelling (Weinberg and Chen, 2013) which has shown to decrease fiber concentrations (Cavali et al., 2010; Chizzotti et al., 2015) and increase digestibility of the fiber portions (Chizzotti et al., 2015), contrary to what was observed. 
A possible explanation for the lower digestibility values can be the effects of the digestibility protocol. This in situ protocol uses a "washout" value to separate watersoluble portions of the sample from the digestible portion in situ. Washout values were relatively high for olive pomace samples resulting in lower reported in situ digestibilities. Previous studies have also found reduced digestibility of olive pomace (Yanez Ruiz et al., Abbeddou et al., 2011). The most probable reasoning could be due to the high oil content of the product, which has proven to reduce bacterial attachment to fiber particles when fed at high concentrations (Hwang et al., 2001). High lipid concentrations may cause detrimental effects on ruminal fermentation, fiber digestion, and DM intake (Manso et al., 2006).

Surprisingly, CAO had the lowest DM digestibility, yet it dissolved the most fiber. For all DM digestibilities, values were lower than the NDF digestibilities (Table 23 and 24). Although this appears to be inaccurate given the digestibility order of nutrients in the rumen, the raw digestibility values for the olive pomace samples were of appropriate proportions for DM and NDF (not reported). Due to the in situ procedure of this experiment (Schroeder et al., 2014), the "washout" samples were very high in DM disappearance resulting in a lower reported DM digestibility. DM digestibility of this given treated olive pomace should be taken under consideration of the digestibility procedure used. 
Table 23: Dry matter digestibility (DMD, \%), following in situ protocol, of olive pomace treated with 3 inoculants

\begin{tabular}{|c|c|c|c|c|}
\hline \multirow[b]{2}{*}{ Incubation } & \multicolumn{4}{|c|}{ Treatment $^{1}$} \\
\hline & CONT & SS & UREA & CAO \\
\hline $12 \mathrm{~h}$ & $8.8187^{\mathrm{A}, \mathrm{a}}$ & $8.6028^{\mathrm{A}, \mathrm{a}}$ & $9.7692^{\mathrm{A}, \mathrm{a}}$ & $9.0821^{\mathrm{A}, \mathrm{a}}$ \\
\hline $24 \mathrm{~h}$ & $15.2911^{\mathrm{B}, \mathrm{a}}$ & $13.7897^{\mathrm{B}, \mathrm{b}}$ & $16.6736^{\mathrm{B}, \mathrm{c}}$ & $14.3254^{\mathrm{B}, \mathrm{a}, \mathrm{b}}$ \\
\hline \multirow[t]{3}{*}{$48 \mathrm{~h}$} & $23.5266^{\mathrm{C}, \mathrm{a}, \mathrm{b}}$ & $24.0587^{\mathrm{C}, \mathrm{a}}$ & $22.8109^{\mathrm{C}, \mathrm{b}}$ & $20.3380^{\mathrm{C}, \mathrm{c}}$ \\
\hline & SEM $^{2}$ & Trt & Incubation & $\begin{array}{c}\text { Trt } x \\
\text { Incubation } \\
\end{array}$ \\
\hline & 1.32 & $<0.001$ & $<0.001$ & $<0.001$ \\
\hline
\end{tabular}

${ }^{\mathrm{A}-\mathrm{E}}$ Means with different superscripts in the same column indicate significance, $P<0.05$

${ }^{\mathrm{a}-\mathrm{d}}$ Means with different superscripts in the same row indicate significance, $P<0.05$

${ }^{1} \mathrm{CONT}=$ no additives; UREA $=$ applied at $5 \%$ of DM; SS $=$ a mixture of Enterococcus faecium M74, Lactococcus lactis SR3.54, and Lactobacillus plantarum CH6072 applied at $1.5 \times 10^{5} \mathrm{cfu} / \mathrm{fresh} \mathrm{g}$; CAO $=\mathrm{SS}$ and calcium oxide applied at $5 \%$ of DM.

${ }^{2} \mathrm{SEM}$, standard error of the mean

Table 24: Neutral detergent fiber digestibility (NDFD, \%), following in situ protocol, of olive pomace treated with 3 inoculants

\begin{tabular}{ccccc}
\hline & \multicolumn{4}{c}{ Treatment $^{\mathbf{1}}$} \\
\cline { 2 - 5 } Incubation & CONT & SS & UREA & CAO \\
\hline $12 \mathrm{~h}$ & $12.7379^{\mathrm{A}, \mathrm{a}}$ & $14.7197^{\mathrm{A}, \mathrm{a}}$ & $14.3732^{\mathrm{A}, \mathrm{a}}$ & $13.6892^{\mathrm{A}, \mathrm{a}}$ \\
$24 \mathrm{~h}$ & $20.3138^{\mathrm{B}, \mathrm{a}, \mathrm{b}}$ & $18.5411^{\mathrm{B}, \mathrm{a}}$ & $21.4720^{\mathrm{B}, \mathrm{b}}$ & $18.4915^{\mathrm{B}, \mathrm{a}}$ \\
$48 \mathrm{~h}$ & $28.6812^{\mathrm{C}, \mathrm{a}}$ & $30.6516^{\mathrm{C}, \mathrm{a}}$ & $26.2698^{\mathrm{C}, \mathrm{b}}$ & $25.2123^{\mathrm{C}, \mathrm{b}}$ \\
& & & & \\
& SEM $^{2}$ & Trt & Incubation & Trt x \\
& 0.018 & $<0.001$ & $<0.001$ & $<0.001$ \\
\hline
\end{tabular}

A-E Means with different superscripts in the same column indicate significance, $P<0.05$

${ }^{\text {a-d }}$ Means with different superscripts in the same row indicate significance, $P<0.05$

${ }^{1} \mathrm{CONT}=$ no additives; UREA $=$ applied at $5 \%$ of DM; SS $=$ a mixture of Enterococcus faecium M74, Lactococcus lactis SR3.54, and Lactobacillus plantarum CH6072 applied at $1.5 \times 10^{5} \mathrm{cfu} / \mathrm{fresh} \mathrm{g}$; CAO $=\mathrm{SS}$ and calcium oxide applied at $5 \%$ of DM.

${ }^{2} \mathrm{SEM}$, standard error of the mean 


\section{CONCLUSIONS}

The preceding study demonstrates the effects of chemical and bacteria inoculants on the nutritive value, in situ digestibility, and ensiling compatibility of olive pomace. At initial application, WSC and $\mathrm{pH}$ were relatively high among all treatments and with ensiling, WSC concentrations decreased with no effect on pH. UREA had higher lactic acid, explaining the rapid onset of WSC reduction with ensiling. A 3-fold increase in crude protein concentration for UREA compared to CONT was observed at all ensiling days. SS began with a higher fat concentration, but this effect was diminished with prolonged ensiling. Among all treatments, $\mathrm{CAO}$ proved to be the most effective inoculant combination. The high acetic acid concentrations reduced yeast counts with ensiling, hindered ethanol formation. Taking these factors into account, this resulted in excellent DM recovery rates for $\mathrm{CAO}$, compared to CONT. Although $\mathrm{CAO}$ reduced fiber components, NDFD was actually reduced by $48 \mathrm{~h}$ along with UREA samples in comparison to CONT. It was determined that ensiling alone is not sufficient for the improvement of the nutritional value of olive pomace, although it does serve as a viable storage method; instead it is most effective in combination with chemical and bacterial inoculants. Overall, olive pomace has shown to be a potentially effective and valuable feed source for cattle. With the addition of chemical and bacterial inoculants, this product's chemical composition can be altered to better suit ones needs. 


\section{REFERENCES}

3M. 2004. Petrifilm- Yeast and Mold Count Plate Interpretation Guide. 3M Microbiology.

3M. 2014. AOAC official method 2014.05 enumeration of yeast and mold in food. AOAC International.

Abbeddou, S., S. Riwahi, L. Iniguez, M. Zaklouta, H.D. Hess, and M. Kreuzer. 2011. Ruminal degradability, digestibility, energy content, and influence on nitrogen turnover of various Mediterranean by-products in fat-tailed Awassi sheep. Anim. Feed Sci. Technol. 163: 99-110. doi:10.1016/j.anifeedsci.2010.10.011

Abdollahzadeh, F., R. Pirmohammadi, P. Farhoomand, F. Fatehi and F.F. Pazhoh. 2010. The effect of ensiled mixed tomato and apple pomace on Holstein dairy cow. Italian J. Anim. Sci., 9 (2): 212-216. DOI: 10.4081/ijas-2010.e41

Alawa, J.P., G. Fishwick, and R.G. Hemingway. 1988. Fresh and dried brewers' grains as protein supplements to barley straw diets given to pregnant beef cows. Anim. Feed Sci. and Technol. 19(1-2): 33-41. DOI: https://doi.org/10.1016/03778401(88)90052-1

Alburquerque, J.A., J. Gonzalvez, D. Garcia, and J. Cegarra. 2004. Agrochemical characterization of "aperujo", a solid by-product of the two-phase centrifugation method for olive oil extraction. Bioresour. Technol. 91, 195-200. doi:10.1016/S0960-8524(03)00177-9

Alburquerque, J.A., J. Gonzalvez, D. Garcia, and J. Cegarra. 2006. Effects of bulking agent on the composition of "alperujo", the solid by-product of the two-phase centrifugation method for olive oil extraction. Process Biochemistry. 41: 127-132. doi:10.1016/j.procbio.2005.06.006

Al-Masri, M.R. 2003. An in In vitro evaluation of some unconventional ruminant feeds in terms of the organic matter digestibility, energy and microbial biomass. Trop. Anim. Health Pro. 35(2): 155-167

Ankom. 2016. Determining acid detergent lignin in beakers. Method 8. Ankom Technology.

Ankom. 2017a. Acid detergent fiber in feeds - filter bag technique (for A2000 and A2000I). Method 12. Ankom Technology.

Ankom. 2017b. Neutral detergent fiber in feeds - filter bag technique (for A2000 and A2000I). Method 13. Ankom Technology.

Ankom. 2017c. Total fat by acid hydrolysis - filter bag technique using the $\mathrm{ANKOM}^{\mathrm{HCl}}$ hydrolysis system. Ankom Technology. 
AOAC (Association of Official Analytical Chemists). 1990. Official Methods of Analysis. $15^{\text {th }}$ ed. Assoc. Off. Anal. Chem., Arlington, VA.

Arco-Perez, A., E. Ramos-Morales, D.R. Yanez-Ruiz, L. Abecia, and A.I. Martin-Garcia. 2017. Nutritive evaluation and milk quality of including of tomato or olive byproducts silages with sunflower oil in the diet of dairy goats. Anim. Feed Sci. Technol. 232, 57-70

Arriola, K.G., S. C. Kim, and A. T. Adesogan. 2011. Effect of applying inoculants with heterolactic or homolactic and heterolactic bacteria on the fermentation and quality of corn silage. J. Dairy Sci. 94:1511-1516

Awawdeh, M.S., and B.S. Obeidat. 2011. Effect of supplemental exogenous enzymes on performance of finishing Awassi lambs fed olive cake-containing diets. Livest. Sci. 138: 20-24. doi:10.1016/j.livsci.2010.11.021

Awawdeh, M.S., and B..S. Obeidat. 2013. Treated olive cake as a non-forage fibber source for growing Awassi lambs: Effects on nutrient intake, rumen and urine $\mathrm{pH}$, performance, and carcass yield. Asian Australas. J. Anim. Sci. 26(5): 661-667. Doi: http://dx.doi.org/10.5713/ajas.2012.12513

Azevedo, J.A.G., S.C. Valadares Filho, D.S. Pina, E. Detmann, L.G.R. Pereira, R.F.D. Valadares, H.J. Fernandes, L.F. Costa e Silva, and P.B. Benedeti. 2012. Nutritional diversity of agricultural and agro-industrial by-products for ruminant feeding. Arq. Bras. Med. Vet. Zootec. 64(5): 1246-1255. Doi: https://dx.doi.org/10.1590/S010209352012000500024.

Bampidis, V.A. and P.H. Robinson. 2006. Citrus by-products as ruminant feeds: A review. Anim. Feed Sci. Technol. 128(3-4): 175-217. DOI: https://doi.org/10.1016/j.anifeedsci.2005.12.002

Barnett, A.J.G. 1954. Silage Fermentation. New York. Academic Press Inc.

Bergman, E.N. 1990. Energy contributions of volatile fatty acids from the gastrointestinal tract in various species. Physiological Reviews. 70(2): 567-590.

Bernard, J.K. 2017. Considerations for using by-product feeds. UGA Extension: Bulletin 862.

Bochicchio, D., M. Comellini, G. Marchetto, V. Faeti, and G. Della Casa. 2015. Modification of Lipid Fraction in Ensiled High Moisture Corn. Ital. J. Anim. Sci. 14:3, 3899. DOI:10.4081/ijas.2015.3899

Bujnak, L., I. Maskalova, and V. Vajda. 2011. Determination of buffering capacity of selected fermented feedstuffs and the effect of dietary acid-base status on ruminal fluid pH. Acta Vet. Brno. 80; 269-173. doi:10.2754/avb201180030269. 
California Olive Oil Council. 2017. http://www.cooc.com.

Cavali, J., O.G. Pereira, S.C. Valadares Filho, E.M. Santos, G.G.P. Carvalho, M.V. Santos, M.O. Porto, and J.F.H. Rodrigues. 2010. Bromatological andmicrobiological characteristics of sugarcane silages treated with calcium oxide. Rev. Bras. Zootec. 39, 1398-1408.

Christodoulou, V., V.A. Bampidis, C.J. Israilides, P.H. Robinson, A. Giouzelyiannis, and A. Vlyssides. 2008. Nutritional value of fermented olive wastes in growing lamb rations. Anim. Feed Sci. Technol. 141, 375-383.

Chizzotti, F.H.M., o.g. Pereira, S.C. Valadares Filho, M.I. Chizzotti, R.T.S. Rodrigues, L.O. Tedeschi, and T.C. Silva. 2015. Does sugar cane ensiled with calcium oxide affect intake, digestibility, performance, and microbial efficiency in beef cattle? Anim. Feed Sci. Technol., 203: 23-32. DOI: http://dx.doi.org/10.1016/j.anifeedsci.2014.12.014

Church, D.C. 1993. The ruminant animal: digestive physiology and nutrition. Prospect Heights, III., Waveland Press.

Clark, C.A., P.J. Gunn, and D.L. Maxwell. 2013. Utilization of pelleted corn stover/DDG feed as primary source of roughage and protein in beef feedlot rations. Iowa State Research Farm Progress Report. Paper 2093.

Connor, D.J. and Fereres, E. 2005. The physiology of adaptation and yield expression in olive. In: Janick (ed) Horticultural reviews. Wiley, Portland, pp 155-229

Cook, D.E., D.K. Combs, P.H. Doane, M.J. Cecava, and M.B. Hall. 2016. The effects on digestibility and ruminal measures of chemically treated corn stover as a partial replacement for grain in dairy diets. J. Dairy Sci., 99: 6342-6351. DOI: http://dx.doi.org/10.3168/jds.2015-10403

Daniel, J.L.P., O.C. M. Queiroz, K.G. Arriola, R. Daetz, F. Basso, J.J. Romero, and A.T. Adesogan. 2018. Effects of homolactic bacterial inoculant on the performance of lactating dairy cows. J. Dairy Sci. 101:1-8

Danner, H., M. Holzer, E. Mayrhuber, and R. Braun. 2003. Acetic scid increases stability of silage under aerobic conditions. Appl. Environ. Microbiol. 69(1):562-567.

Denek, N. and A. Can. 2006. Feeding value of wet tomato pomace ensiled with wheat straw and wheat grain for Awassi sheep. Small Rumin. Res. 65(3): 260-265. Doi: https://doi.org/10.1016/j.smallrmres.2005.06.024.

Duniere, L., J. Sindou, F. Chaucheyras-Durand, I. Chevallier, and D. Thevenot-Sergentet. 2013. Silage processing and strategies to prevent persistence of undesirable microorganisms. Anim Feed Sci Technol. 182 (1-4): 1-15. Doi: 10.1016/j.anifeedsci.2013.04.006 
Ellis, N.R. and H.R. Bird. 1951. Byproducts as feed for livestock. Yearbook of Agriculture. 851-862.

Felix, T. L., T. A. Murphy, and S. C. Loerch. 2012. Effects of dietary inclusion and $\mathrm{NaOH}$ treatment of dried distillers grains with solubles on ruminal metabolism of feedlot cattle. J. Anim. Sci. 90:4951-4961.

Field, T.G. and R.E. Taylor. 2011. Scientific farm animal production: an introduction to animal science. $10^{\text {th }}$ ed. Prentice Hall, New York NY.

Food and Agriculture Organization. 2017. FAOSTAT database. Available from $<$ http://apps.fao.org/default.htm>.

Garcia, I.M., D.Y. Ruiz, A. Moumen, and E.M. Alcaide. 2005. Effect of polyethylene glycol, urea and sunflower meal on olive (Olea europaea var. europaea) leaf fermentation in continuous fermenters. Small Ruminant Research. 61, 53-61.

Gibb, D.J., X. Hao, and T.A. McAllister. 2008. Effect of dried distillers' grains from wheat on diet digestibility and performance of feedlot cattle. Can. J. Anim. Sci. 88: 659665 .

Gould, K. 2011. Corn stover makes excellent beef cow feed, run your numbers. Michigan State University Extension. http://msue.anr.msu.edu/news/corn_stover_makes_ excellent_beef_cow_fee d_run_your_numbers

Grasser, L.A., J.G. Fadel, I. Garnett, E. Depeters. 1995. Quantity and economic importance of 9 selected by-products used in California dairy rations. J. Dairy Sci. 78, 962-971.

Gunn, P.J., A.D. Weaver, R.P. Lemenager, D.E. Gerrard, M.C. Claeys, and S.L. Lake. 2009. Effects of dietary fat and crude protein on feedlot performance, carcass characteristics, and meat quality in finishing steers fed differing levels of dried distillers grains with solubles'. J. Anim. Sci. 87(9): 2882-2890. DOI: https://doi.org/10.2527/jas.2008-1521

Hadjipanayiotou, M. 1994. Voluntary intake and performance of ruminant animals offered poultry litter-olive cake silage. Livest. Res. Rural Dev., 6: 1-9.

Hadjipanayiotou, M. 1999. Feeding ensiled crude olive cake to lactating Chios ewes, Damascus goas and Friesian cows. Livest. Prod. Sci. 59:61-66.

Hammami, S.B.M., G. Costagli, H.F. Rapoport. 2013. Cell and tissue dynamics of olive endocarp sclerification vary according to water availability. Physiol Plant 149:571582 
Heinrichs, A. and H. Conrad. 1984. Fermentation characteristics and feeding value of ammonia-treated corn silage. J. Dairy Sci. 67, 82-87.

Hwang, I.H., H.D. Kim, S.S. Shim, S.S. Lee, and J.K. Ha. 2001. Effect of unsaturated fatty acids on cellulose degradation and fermentation characteristics by mixed ruminal microbes. Asian-Aust. J. Anim. Sci 14 (4): 501-506.

Index Mundi. 2018. https://www.indexmundi.com/

International Olive Oil Council. 2017. http://www.internationaloliveoil.org. Jackson, M.G.

1977. Review article: the alkali treatment of straws. Anim. Feed Sci.

Technol. 2, 105-130.

Jacovaci, F.A., C.C. Jobim, P. Schmidt, L.G. Nussio, and J.L.P. Daniel. 2017. A dataanalysis on the conservation and nutritive value ofsugarcane silage treated with calcium oxide. Anim. Feed Sci. Technol. 225 (2017) 1-7. ttp://dx.doi.org/10.1016/j.anifeedsci.2017.01.005

Jenkins, T.C. 1993. Lid metabolism in the rumen. Symposium: Advances in ruminant lipid metabolism. J. Dairy Sci 73: 3851-3863.

Kennedy, M., D. List, Y. Lu, R.H. Newman, I.M. Sims and P.J.S. Bain. 1999. Apple Pomace and Products Derived from Apple Pomace: Uses, Composition and Analysis of Plant Waste Materials. Italian J Anim Scie. 20: 75-119

Klopfenstein, T. 1978. Chemical treatment of crop residues. J. Anim. Sci. 46, 841-848.

Kraut-Cohen, J., V. Tripathi, Y. Chen, J. Gatica, V. Volchinski, S. Sela, Z. Weinberg, and E. Cytryn. 2016. Temporal and spatial assessment of microbial communities in commercial silages from bunker silos. App. Microbiol.

Biotechnol. 100(15): 6821-6835.

Kung, L., and R. Shaver Jr. 2001. Interpretation and use of silage fermentation analysis reports. Focus on Forage 3:1-5.

Kung Jr., L. 2003. Silage science and technology. In D. R. Buxton, R. E. Muck, \& J. H. Harrison (Eds.), Silage additives (pp. 251-304). Madison: American Society of Agronomy, Crop Society of America, Soil Science Society of America.

Kung, Jr., L. 2011. Silage fermentation \& additives. Accessed Oct. 25, 2016. http://www1.foragebeef.ca/\$Foragebeef/frgebeef.nsf/all/frg69/\$FILE/silageferme ntationadditives.pdf

Lalman, D.L., and H.B. Sewell. 1993. Rations for growing and finishing beef cattle. University of Missouri Extension Publication G2066. http://extension.missouri.edu/publications/DisplayPub.aspx?P=G2066 
Li, H.Y., L. Xu, W.J. Liu, M.Q. Fang, and N. Wang. 2014. Assessment of the Nutritive Value of Whole Corn Stover and Its Morphological Fractions. Asian-Australian J Anim Sci. 27(2): 194-200. DOI: 10.5713/ajas.2013.13446

Loy, T.W., J.C. MacDonald, T.J. Klopfenstein and G.E. Erickson. 2007. Effects of distillers grains or corn supplementation frequency on forage intake and digestibility. J. Anim. Scie. 85: 2625-2630. doi:10.2527/jas.2005-750

Manso T., T. Castro, A. R. Mantecón, and V. Jimeno. 2006. Effects of palm oil and calcium soaps of palm oil fatty acids in fattening diets on digestibility, performance and chemical body composition of lambs. Anim. Feed Sci. Technol. 127:175-186.

Martin Garcia, A.I., A. Moumen, D.R. Yanez Ruiz, and E. Molina Alcaide. 2003. Chemical composition and nutrients availability for goats and sheep of two- stage olive cake and olive leaves. Anim. Feed Sci. Technol. 107: 61-74. doi:10.1016/S03778401(03)00066-X

Martin Garcia, A.I., D.R. Yanez Ruiz, A. Moumen, and E. Molina Alcaide. 2004. Effect of polyethylene-glycol on the chemical composition and nutrient availability of olive (Olea europaea var. europaea) by-products. Anim. Feed Sci. Technol.114: 159-177. doi:10.1016/j.anifeedsci.2004.01.003

McDonald, P., A.R. Henderson, and S.J.E. Heron. 1991. The biochemistry of silage, $2^{\text {nd }}$ edition. Chalcombe Publ, Cambrian Printers, Ltd, Wales, UK

McGarvey, J.A., R.B. Franco, J.D. Palumbo, R. Hnasko, L. Stanker, and F.M. Mitloehner. 2013. Bacterial population dynamics during the ensiling of Medicago sativa (alfalfa) and subsequent exposure to air. J. of Appl. Micro. 114(6) · Doi: 10.1111/jam.12179

McSweeney, C.S., B. Palmer, D.M. McNeill, and D.O. Krause. 2001. Microbial interactions with tannins: nutritional consequences for ruminants. Anim Feed Sci Technol. 91: 83-93.

Meeske, R., Basson, H.M., 1998. The effect of a lactic acid bacterial inoculant on maize silage. Anim. Feed Sci. Technol. 70, 239-247

Meeter, W.C., L.M. Shoup, W.P. Chapple. W.T. Metter PAS, and D.W. Shike. 2018. Effects of feeding high-moisture corn stover to gestating and lactating beef cows as an alternative to hay and corn silage on performance and reproduction. The Professional Animal Scientist. 34(2): 210-217. DOI: https://doi.org/10.15232/pas.2017-01675

Miller, A. J., D. B. Faulkner, R. K. Knipe, D. R. Strohbehn, D. F. Parrett, and L. L. Berger. 2001. Critical control points for profitability in the cow-calf enterprise. Prof. Anim. Sci. 17:295 
Molina Alcaide, E., and A. Nefzaoui. 1996. Recycling of olive oil by-products: possibilities of utilization in animal nutrition. Int. Biodet. Biodeg. 38: 227- 235.

Molina Alcaide, E., D. Yanez Ruiz, A. Moumen, and I. Martin Garcia. 2003. Chemical composition and nitrogen availability for goats and sheep of some olive by-products. Small Rumin. Res. 49: 329-336. doi:10.1016/S0921- 4488(03)00148-2

Moran, J. 2005. How the rumen works. In: Tropical dairy farming: feeding management for small holder dairy farmers in the humid tropics. Landlinks Press.

Nadeau, E.M.G. and S.K. Barnhart. 2008. The ensiling process and additives. Iowa State University Extension. Agronomy 3-4

Nefzaoui, A., Vanbelle, M., 1986. Effects of feeding alkali-treated olive cake on intake, digestibility and rumen liquor parameters. Anim. Feed Sci. Technol. 14, 139-149.

Oladosu, Y., M. Y. Rafli, N. Abdullah, U. Magaji, G. Hussin, A. Ramli, and G, Miah. 2016. Fermentation quality and additives: a case of rice straw silage. Biomed. Res. Int. http://dx.doi.org/10.1155/2016/7985167

Ojowi, M., J.J. McKinnon, A.F. Mustafa, and D.A. Christensen. 1997. Evaluation of wheatbased wet distillers' grains for feedlot cattle. Can. J. Anim. Sci. 77:447- 454. DOI: https://doi.org/10.4141/A96-117

Owaimer, A.N., M.S. Kraidees, A. Al-saiady, S. Zahran, and M.A. Abouheif. 2004. Effect of Feeding Olive Cake in Complete Diet on Performance and Nutrient Utilization of Lambs. Asian-Aust. J. Anim. Sci. 17(4) : 491-49.zi

Owens, F.N., Meiske, J., Goodrich, R., 1969. Effects of calcium sources and urea on corn silage fermentation. J. Dairy Sci. 52, 1817-1822

Pahlow, G., R.E. Muck, F. Driehuis, S.J.W.H. Oude Elferink, and S. F. Spoelstra. 2003. Microbiology of ensiling. In: D.R. Buxton, R.E. Muck, and J.H. Harrison, editors, Silage science and technology. American Society of Agronomy. P. 31-93. Doi: 10.2134/agronmonogr42.c2

Paiva-Martins, F., T. Ribeirinha, A. Silva, R. Goncalves, V. Pinheiro, J.L. Mourao, and D. Outor-Monteiro. 2014. Effects of the dietary incorporation of olive leaves on growth performance, digestibility, blood parameters and meat quality of growing pigs. J Sci Food Agric, 94: 3023-3029. DOI: 10.1002/jsfa.6650

Parish, J.A., B.B. Karisch, and J.D. Rivera. 2017. Feedstuffs for beef cattle. Mississippi State University Extension Service. https://extension.msstate.edu/sites/ default/files/publications/publications/P2834.pdf 
Rapoport, H.F., A. Fabbri, and L. Sebastiani. 2016. Olive Biology. In: E. Rugini et al., editors, The Olive Tree Genome, Compendium of plant genomes. DOI 10.1007/9783-319-48887-5_2

Rogers, J.A., H.R. Conrad, B.A. Dehority, and J.A. Grubb. 1986. Microbial Numbers, Rumen Fermentation, and Nitrogen Utilization of Steers Fed Wet or Dried Brewers' Grains. J Dairy Sci. 69(3): 745-753. DOI: https://doi.org/10.3168/jds.S00220302(86)80463-5

Roth, G., and D. Undersander. 1995. Corn silage production, management, and feeding. ASA, CSSA, and SSSA, Madison, WI. doi:10.2134/asaspecpub58

Rowgani, E., M.J. Zamiri, and A.R. Seradj. 2008. The chemical composition, rumen degradability, in vitro gas production, energy content and digestibility of olive cake ensiled with additives. Iranian Journal of Veterinary Research. 9(3)

Santos, M.C., L.G. Nussio, G.B. Mourão, P. Schmidt, L.J. Mari, and J.L. Ribeiro. 2008. Influência da utilizac, ão de aditivos químicos no perfil da fermentac, ão, novalor nutritivo e nas perdas de silagens de cana-de-ac, úcar (Evaluation of chemical additives in the fermentation profile, nutritive value, and drymatter losses of sugarcane silages (Saccharum officinarum L.)). Rev. Bras. Zootec. 37, 1555-1563 (Eng. Abstr.).

Schmidt, P. 2006. Fermentative losses in silage, digestive parameters and performance of beef cattle fed with sugar cane silage (228f. Tese (Thesis Doctor Science), Escola Superior de Agricultura Luiz de Queiroz, USP, Piracicaba.

Schroeder, A.R., M.J. Duckworth, D.W. Shike, J.P. Schoonmaker, and T.L. Felix. 2014. Effects of calcium oxide treatment of dry and modified wet corn distillers grains plus solubles on growth performance, carcass characteristics, and apparent digestibility of feedlot steers. J. Anim. Sci. 92: 4661-4668. DOI: 10.2527/jas20147893

Scott, T., T.J. Klopfenstein, D. Shain, and M. Klemesrud. 1997. Wet corn gluten feed as a source of rumen degradable protein for finishing steers. Nebraska Beef Cattle Reports. 456. http://digitalcommons.unl.edu/animalscinbcr/45

Sesli, M., Yeğenoğlu, E.D., 2009. RAPD-PCR analysis of cultured type olives in Turkey. African J. Biotechnol. 8, 3418-3423.

Shi, H.T., S.L. Li, Z. J. Cao, Y. J. Wang, G. M. Alugongo, and P. H. Doane. 2015. Effects of replacing wild rye, corn silage, or corn grain with $\mathrm{CaO}$-treated corn stover and dried distillers grains with solubles in lactating cow diets on performance, digestibility, and profitability. J. Dairy Sci. 98:7183-7193

Siegfried, V. R., H. Ruckemmann, and G. Stumpf. 1984. Method for the determination of organic acids in silage by high performance liquid chromatography. Landwirtsch. Forsch. 37:298-304. 
Sirohi, S. K., and S. N. Rai. 1998. Optimisation of treatment conditions of wheat straw with lime: Effect of concentration, moisture content and treatment time on chemical composition and in vitro digestibility. Anim. Feed Sci. Technol. 74: 57-62.

Stern, M.D., and C.J. Ziemer. 1995. By-product feeds as energy sources for ruminants. The professional animal scientist. 11(2): 51-66. Doi: https://doi.org/10.15232/S10807446(15)32557-2.

Theriez, M. and G. Boule. 1970. Valeur alimentaire du tourteau d'olive. Ann. Zootech., 19 (2): 143-157. DOI: http://dx.doi.org/10.1051/animres:19700203

Tortosa, G., J.A. Alburquerque, G. Ait-Baddi, and J, Cegarra. 2012. The production of commercial organic amendments and fertilisers by composting of two-phase olive mill waste (“alperujo"). J. Clean. Prod. 26: 48-55. doi:10.1016/j.jclepro.2011.12.008

Tournas, V., M.E. Stack, P.B. Mislivec, H.A. Koch, and R. Bandler. 2001. BAM: Yeasts, molds and mycotoxins. FDA: U.S. Food and Drug Administration.

Trenkle, A.H., L.L. Berger, T.W. Perry, R.J. Brandt, S.R. Rust, B. Larson, J.E. Williams, R.A. Stock, W.P. Weiss, S.C. Loerch, R.H. Pritchard, D.M. Schaefer, J.H. Eisemann, C.R. Richards, and D.G. Topel. 1989. Corn gluten feed in beef cattle diets. North central regional research publication. 319 .

VanNevel, C.J. and D.I. Demeyer. 1988. Manipulation of rumen fermentation. In: The rumen microbial ecosystem. P.N. Hobson, Elsevier Applied Sciences, London. 387443

Van Soest, P. J. 1994. Nutritional ecology of the ruminant. 2nd ed. Cornell University Press, Ithaca, NY.

Vargas-Bello-Perez, E., R.R. Vera, C. Aguilar, R. Lira, I. Pena, and J. Fernandez. 2013. Feeding olive cake to ewes improves fatty acid profile of milk and cheese. Anim. $\begin{array}{lllll}\text { Feed } & \text { Sci. } & \text { Technol. } & \text { 184: } & \text { 94-99. }\end{array}$ http://dx.doi.org/10.1016/j.anifeedsci.2013.05.016

Vieira, D. A., A. S. Cezario, T. N. P. Valente, J. C. Ribeiro, W. B. R. Santos, and P. R. N. Ferreira. 2017. Evaluation of the addition of urea or calcium oxide $(\mathrm{CaO})$ on the recovery of dry matter of the by-product of sweet corn silage. J. Agric. Sci. doi:10.5539/jas.v9n9p141

Wang, H., T. Ning, W. Hao, M. Zheng, and C. Xu. 2016. Dynamics associated with prolonged ensiling and aerobic deterioration of total mixed ration silage containing whole crop corn. Asian Australas. J. Anim. Sci. 29(1): 62-72. Doi: http://dx.doi.org/10.5713/ajas.15.0319 
Weinberg, Z.G., and Y. Chen. 2013. Effects of storage period on the composition of whole crop wheat and corn silages. Ani Feed Sci and Technol. 185(3- 4): 196- 200.

Weinberg, Z.G. and R.E. Muck. 1996. New trends and opportunities in the development and use of inoculants for silage. FEMS Microbiological Reviews 19: 53-68

Xiccato, G., M. Cinetto, A. Carazalo, and M.E. Cossu. 1994. The effect oof silo type and dry matter content on the maize silage fermentation process and ensiling loss. Anim. Feed Sci. Technol. 49:311-323

Zaman, M. S., and E. Owen. 1995. The effect of calciom hydroxide and urea treatment of barley straw on chemical composition and digestibility in vitro. Anim. Feed Sci. Technol. 51:165-171. DOI: 10.1016/0377-8401(94)00669-Z

Zimmer, E. 1969. Biochemische Grundlagen der Einsäuerung. In Proc. Congr. Eur. Grassl. Fed., 3rd. Braunschweig, Germany. 9 (14) 113-115 